\title{
Hydrogeology and Results of Tracer Tests at the Old Tampa Well Field in Hillsborough County, with Implications for Wellhead-Protection Strategies in West-Central Florida
}

\section{By James L. Robinson}

U.S. Geological Survey

Water-Resources Investigations Report 93-4171

Prepared in cooperation with the

SOUTHWEST FLORIDA WATER MANAGEMENT DISTRICT 


\title{
U.S. DEPARTMENT OF THE INTERIOR BRUCE BABBITT, Secretary
}

\author{
U.S. GEOLOGICAL SURVEY \\ GORDON P. EATON, Director
}

For additional information write to:

District Chief

U.S. Geological Survey

Suite 3015

227 N. Bronough Street

Tallahassee, FL 32301
Copies of this report can be purchased from:

U.S. Geological Survey

Earth Science Information Center

Open-File Reports Section

Box 25286, MS 517

Denver Federal Center

Denver, CO 80225 


\section{CONTENTS}

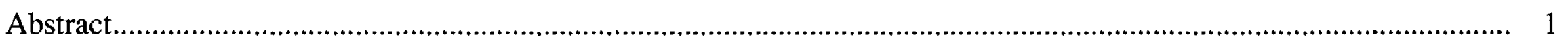

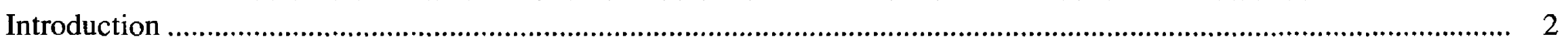

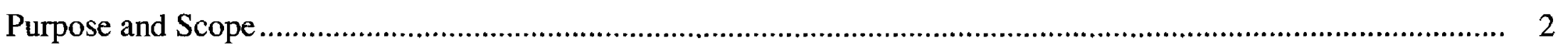

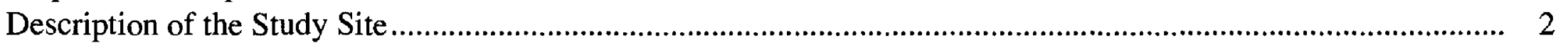

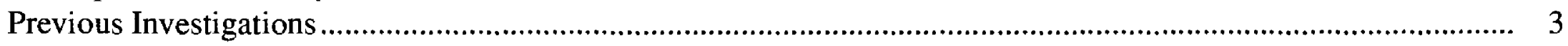

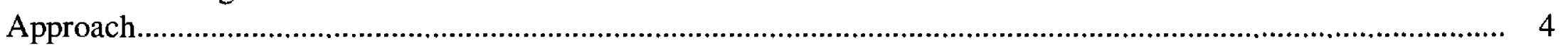

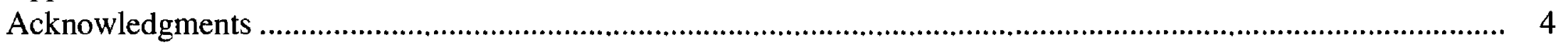

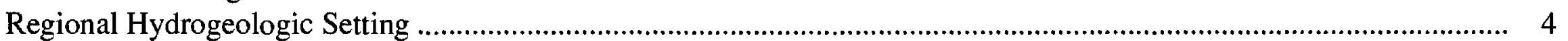

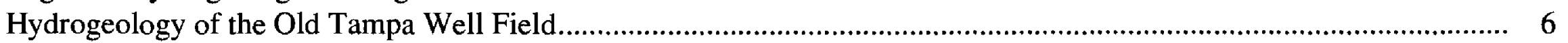

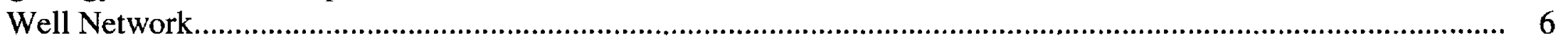

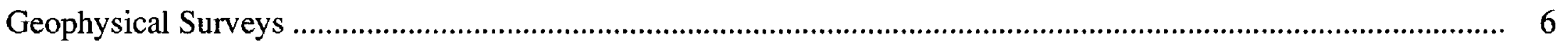

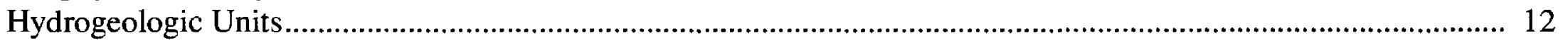

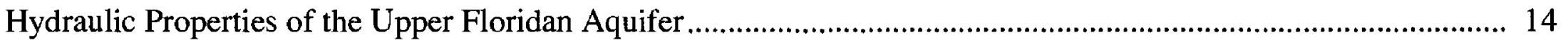

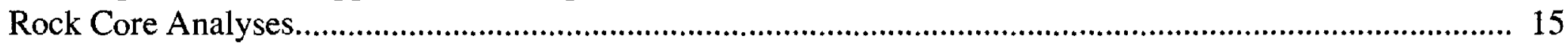

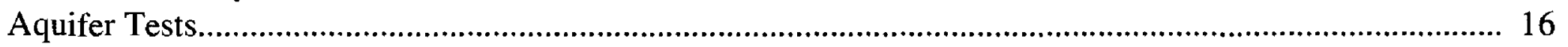

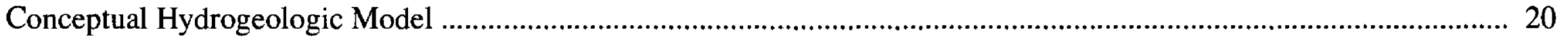

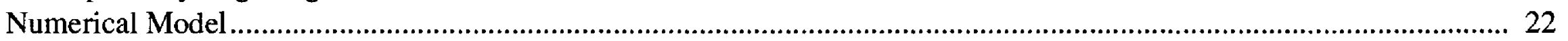

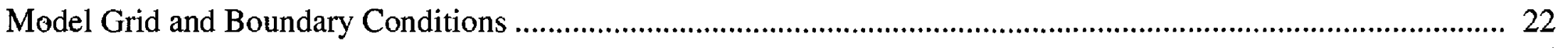

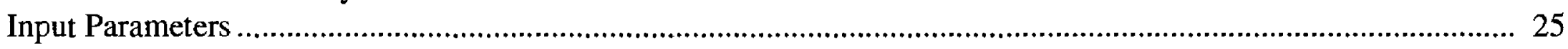

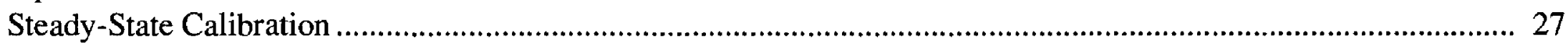

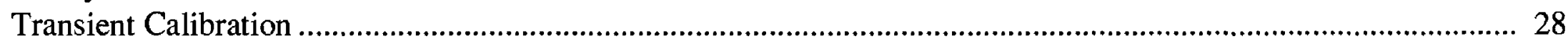

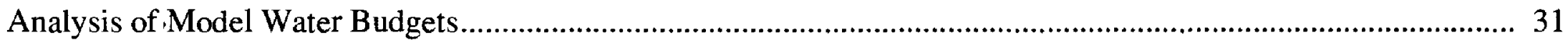

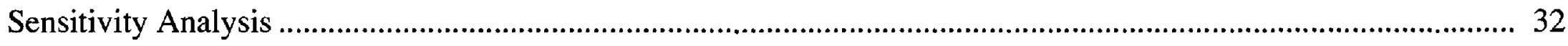

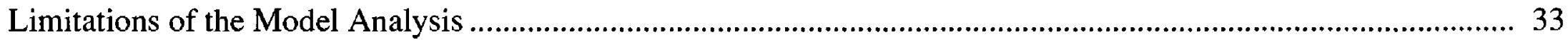

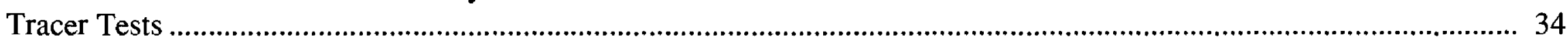

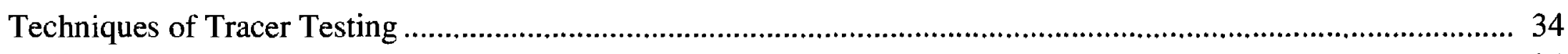

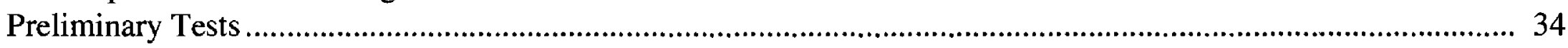

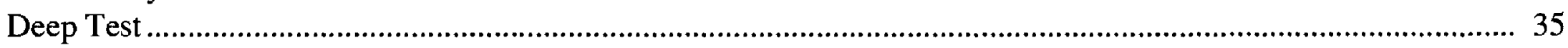

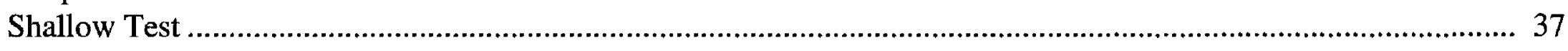

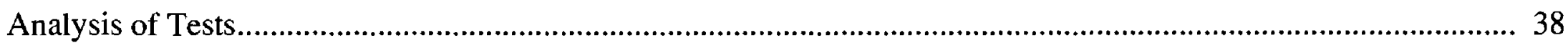

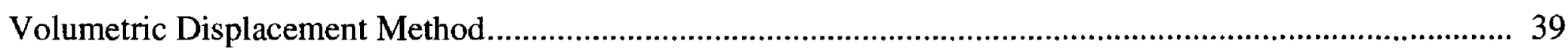

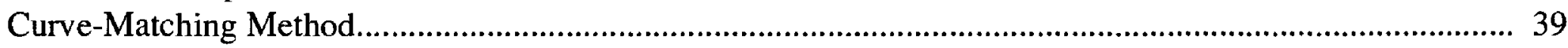

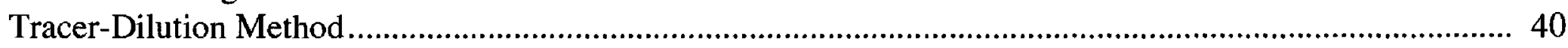

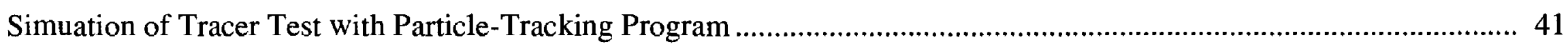

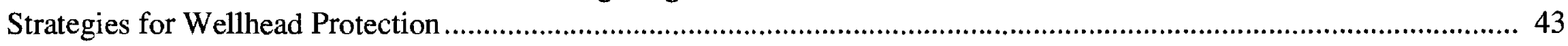

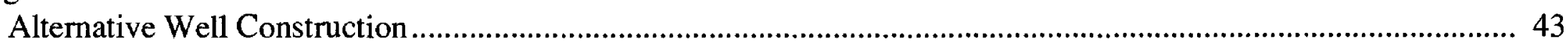

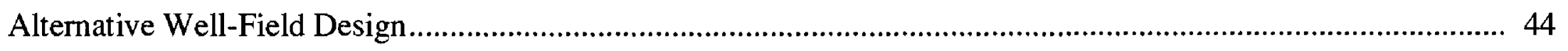

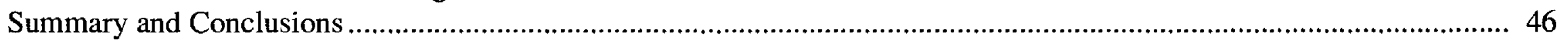

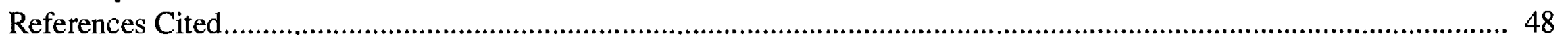

Appendix.--Apparent Secondary Porosity Logs from Borehole Video Survey ....................................................... 51 
1. Map showing location of the old Tampa well field ....

2. Generalized hydrogeologic framework of Hillsborough County ............................................................... 5

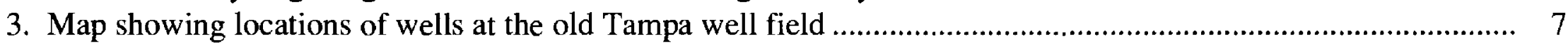

4. Map showing locations of photolineaments and line of surface geophysical survey at the old Tampa well field.... 9

5. Profile showing ground-penetrating radar record near well 17 and hydrogeologic interpretation........................... 10

6. Diagrams showing electromagnetic geophysical records at the old Tampa well field and hydrogeologic

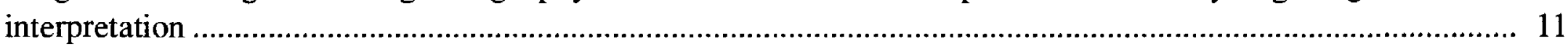

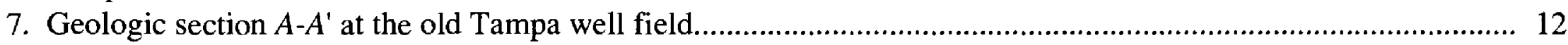

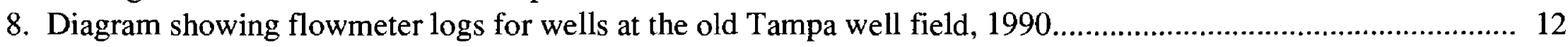

9. Diagram showing identification of effective secondary porosity in well $15 \mathrm{~A}$ using borehole geophysical

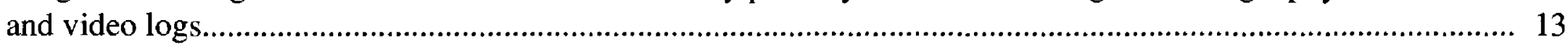

10. Diagram showing effective secondary porosity logs for wells $15,15 \mathrm{~A}$, and the Ocala monitor well and a

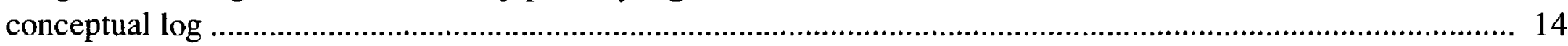

11. Map showing thickness of the intermediate confining unit in the vicinity of the old Tampa well field .................. 15

12-15. Graphs showing:

12. Relation between pumping rate and drawdown in the Upper Floridan aquifer at the old Tampa well field, 1990.

13. Distance-drawdown plot for Upper Floridan aquifer wells at the old Tampa well field, 1990, after 1 minute, 20 minutes, and 48 hours of pumping well 15 at 980 gallons per minute............................. 18

14. Time-drawdown data for Upper Floridan aquifer wells 19 and 20 at the old Tampa well field, $1990 \ldots \ldots \ldots . . . .119$

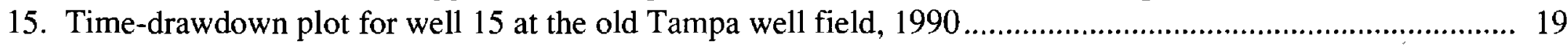

16. Diagram showing the hydrogeologic framework at the old Tampa well field ................................................... 21

17. Diagram showing the hydrogeologic framework of the numerical model of the ground-water flow system

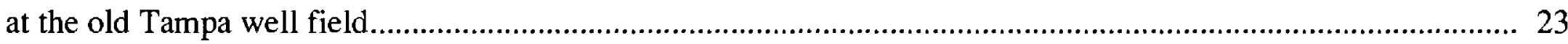

18. Diagram showing node locations of wells in the numerical model of the old Tampa well field .......................... 24

19. Map showing orientation of the numerical model grid to the local potentiometric surface of the Upper Floridan aquifer, July 1990

20. Graph showing simulated drawdowns in permeable unit two of the Upper Floridan aquifer for the uniform transmissivity model and for models using increased and decreased transmissivity in nodes simulating a fracture zone.....

21. Graph showing measured and model-simulated water-level drawdowns at the old Tampa well field for aquifer tests of July and December 1990 .

22. Diagram of the tracer injection and withdrawal system at the old Tampa well field. 35

23. Graph showing dye-concentration curve for well 15 during the Rhodamine WT dye test ending November 18, 1990

24. Diagram showing correlation between effective secondary porosity and tracer concentration in well 11 at the old Tampa well field.

25. Graph showing dye-concentration curve for well 15 during the Rhodamine WT dye test ending April 6, $1991 \ldots . .38$

26. Graph showing analysis of the dye-concentration data for well 15 for the test ending November 18, 1990, using the Laplace transform solution for radially convergent flow

27. Diagram of the MODPATH particle-tracking simulation of the matrix flow for the dye test ending

November 18, 1990, assuming a uniform effective porosity of 21 percent for the Upper Floridan aquifer.

28-31. Maps showing simulated area of contribution encompassed:

28. By the 10-year time of travel from permeable unit one to a well completed in permeable units one and two of the Upper Floridan aquifer.

29. By the 30-year time of travel from permeable unit one to a well completed in permeable units two and three of the Upper Floridan aquifer.

30. By the 30-year time of travel from permeable unit one to two wells completed in permeable units two and three of the Upper Floridan aquifer and aligned parallel to the regional ground-water flow

31. By the 30-year time of travel from permeable unit one to two wells completed in permeable units two and three of the Upper Floridan aquifer and aligned perpendicular to the regional ground-water flow 


\section{TABLES}

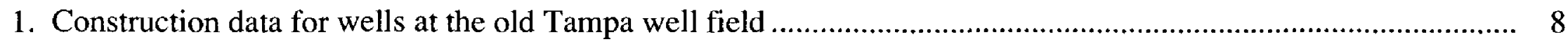

2. Types of borehole geophysical logs available for Upper Floridan aquifer wells at the old Tampa well field .......... 8

3. Reported hydraulic properties of the Upper Floridan aquifer at the old Tampa well field.................................... 15

4. Analyses of rock cores collected from the Upper Floridan aquifer in Hillsborough, Pasco, Pinellas, and Polk Counties, Florida

5. Total drawdown in selected wells at the old Tampa well field during aquifer tests of July and December 1990

6. Input parameters for model of the old Tampa well field

7. Measured and model-simulated drawdowns in the Upper Floridan aquifer at the old Tampa well field for steady-state calibration of two aquifer tests

8. Water budgets for the Upper Floridan aquifer for steady-state and transient simulations of 50-hour and 168-hour aquifer tests at the old Tampa well field in June and December 1990

9. Results of model sensitivity analysis based on simulation of the 50-hour aquifer test. 33

10. Horizontal hydraulic conductivity estimates based on tracer dilution in the injection well 41

11. Areas of contribution simulated for four wellhead-protection strategies. 


\begin{tabular}{rll} 
Multiply & By & To obtain \\
inch (in.) & & millimeter \\
foot $(\mathrm{ft})$ & 25.4 & meter \\
foot per hour $(\mathrm{ft} / \mathrm{h})$ & 0.3048 & meter per hour \\
foot per day $(\mathrm{ft} / \mathrm{d})$ & 0.3048 & meter per day \\
mile $(\mathrm{mi})$ & 0.3048 & meter per day per meter \\
foot per day per foot $[(\mathrm{ft} / \mathrm{d}) / \mathrm{ft}]$ & 1.3048 & kilometer \\
foot squared $\left(\mathrm{ft}^{2}\right)$ & 1.609 & meter squared \\
foot squared per day $\left(\mathrm{ft}^{2} / \mathrm{d}\right)$ & 0.09290 & meter squared per day \\
square mile $\left(\mathrm{mi} \mathbf{2}^{2}\right)$ & 0.09290 & square kilometer \\
$\mathrm{acre}$ & 2.590 & hectare \\
cubic foot $\left(\mathrm{ft}^{3}\right)$ & 0.4047 & cubic meter \\
cubic meter per day \\
cubic foot per day $\left(\mathrm{ft}^{3} / \mathrm{d}\right)$ & 0.02832 & liters per second \\
million gallon per minute $\left(\mathrm{gal} / \mathrm{min}^{2}\right)$ & 0.02832 & cubic meters per day \\
\hline
\end{tabular}

Temperature in degrees Fahrenheit $\left({ }^{\circ} \mathrm{F}\right)$ may be converted to degrees Celsius $\left({ }^{\circ} \mathrm{C}\right)$ as follows:

$$
{ }^{\circ} \mathrm{C}=5 / 9 \times\left({ }^{\circ} \mathrm{F}-32\right) \text {. }
$$

Sea level: In this report, "sea level" refers to the National Geodetic Vertical Datum of 1929 (NGVD of 1929)--a geodetic datum derived from a general adjustment of the first-order level nets of the United States and Canada, formerly called Sea Level Datum of 1929.

\section{Acronyms}

$\mathrm{EM}=$ electromagnetic

FDEP = Florida Department of Environmental Protection

GPR = ground-penetrating radar

ROMP = Regional Observation Monitoring Program

SWFWMD = Southwest Florida Water Management District

USGS = U.S. Geological Survey

WCRWSA = West Coast Regional Water Supply Authority

\section{Additional abbreviations}

$$
\begin{aligned}
& \mathrm{ft} / \mathrm{ft}=\text { foot per foot } \\
& \mathrm{kHz}=\text { kilohertz } \\
& \mathrm{MHz}=\text { megahertz } \\
& \min =\text { minute } \\
& \mathrm{ppb}=\text { parts per billion }
\end{aligned}
$$




\title{
Hydrogeology and Results of Tracer Tests at the Old Tampa Well Field in Hillsborough County, with Implications for Wellhead-Protection Strategies in West-Central Florida
}

\author{
By James L. Robinson
}

\section{Abstract}

The Upper Floridan aquifer of west-central Florida, composed of a thick sequence of primarily Eocene age carbonate rocks, is the primary source of public water supply in Hillsborough County, Florida. The aquifer is at risk from sources of contamination at land surface over much of the area, because the sediments that overlie the aquifer do not prevent downward movement of water. An evaluation of wellhead-protection strategies for the Upper Floridan aquifer was conducted using a 40-acre site in northeastern Hillsborough County as a test case. Carbonate rocks were penetrated from about 50 feet below land surface to a depth of 800 feet. Limestone is the predominant rock above 550 feet and dolomite the predominant rock below that depth.

The results of drilling and aquifer testing at the site indicate that the Upper Floridan aquifer consists of layers of permeable and less permeable units. The upper 400 feet of the aquifer responded to pumping as an equivalent porous medium for a range of discharge rates from 450 to 1,000 gallons per minute. Transmissivity and storage coefficient values estimated for the upper 400 feet of the aquifer were on the order of 23,000 feet squared per day and $10^{-4}$, respectively. Effective porosity values of rock cores collected at the site ranged from 21 to 46 percent.

A numerical aquifer-simulation model of the Upper Floridan aquifer was constructed and calibrated using the results of two aquifer tests performed at the site. Results of numerical modeling support the proposed hydrogeologic model of a layered aquifer with semiconfining units retarding vertical movement of water. These results indicate that the transmissivity of the upper 400 feet of the Upper Floridan aquifer is about 20,000 feet squared per day, the total transmissivity is on the order of 60,000 feet squared per day, and the storage coefficient is on the order of $10^{-4}$.

Two tracer tests were performed using salt and two were performed using a fluorescent dye injected into the open-hole interval of a well and then measuring the movement of the tracer induced by pumping a nearby well at a rate of 980 gallons per minute. Movement of water spiked with salt was monitored with fluid resistivity logging. Results of tracer tests using salt indicated a direct hydraulic connection between the pumped well and the injected well 25 feet away. Fluorescent dye was injected into a well 200 feet from the pumped well at depths of 40 to 340 feet below land surface. Concentration of the fluorescent dye in the water discharged from the pumped well was measured continuously with a fluorometer. A dye breakthrough occurred about 4 hours after pumping began, and concentration peaked after 15 hours of pumping. A second dye breakthrough occurred after 36 days, and dye concentration peaked after 48 days. The bimodal distribution of tracer arrival indicates a dual porosity ground-water flow system. Analysis of tracer test results indicate an effective porosity of 25 percent and a longitudinal dispersivity of 1.3 feet for the aquifer matrix. 
The particle-tracking program MODPATH was used to simulate the ground-water travel times measured during tracer tests. A range of effective porosity of 0.3 to 1.5 percent produced a travel time of 15 hours, approximating the observed 15-hour time to peak concentration of the first tracer arrival. An effective porosity of 21 percent produced a travel time of 49 days, closely approximating the observed time to peak concentration of the second tracer arrival.

A wellhead-protection strategy, utilizing the less permeable units in the Upper Floridan aquifer as a flow barrier between sources of contamination at land surface and the pumped zone of the aquifer, was evaluated. The particle-tracking program MODPATH was used to delineate the areas of contribution from the aquifer matrix for hypothetical well and well-field designs. Results of model runs indicate that limiting withdrawal of water to permeable units below less permeable units, pumping at a rate of less than 980 gallons per minute, and the orientation of multiple wells in a line perpendicular to the local ground-water gradient reduced the total area of contribution from overlying layers to the pumped well(s), thereby reducing the potential for contamination from sources at land surface.

The results of this study demonstrate the heterogeneity of the Upper Floridan aquifer. An effective porosity value too low to be representative of the matrix of the Upper Floridan aquifer was necessary for the equivalent porous media model to simulate the first arrival of a dye tracer, supporting the hypothesis of ground-water flow through secondary porosity. However, the use of uniform porosity models and particle-tracking to simulate the results of tracer tests successfully simulated ground-water flow through the aquifer matrix. Vertical movement of water in the Upper Floridan aquifer was dominated by matrix flow.

\section{INTRODUCTION}

The principal source of municipal water supply in west-central Florida is the Upper Floridan aquifer. In northern Hillsborough and Pasco Counties, the top of the aquifer is about $50 \mathrm{ft}$ below land surface. The aquifer is at risk from sources of contamination at land surface because the sediments that overlie the aquifer do not prevent downward movement of water (Swancar and Hutchinson, 1992). The Florida Department of Environmental Protection (FDEP) has enacted regulations that limit the amount and type of land use near well fields to protect public water supplies. The FDEP has not mandated a methodology for delineation of wellhead-protection zones; that responsibility has been delegated to the counties.

The U.S. Geological Survey (USGS), in cooperation with the Southwest Florida Water Management District (SWFWMD), initiated a study in 1989 to collect the hydrogeologic data needed to evaluate ground-water flow near wells pumping from the Upper Floridan aquifer. The data were used to evaluate wellhead-protection strategies for west-central Florida. The study site is the old Tampa well field, an area of eastern Hillsborough County in which hydrogeologic conditions are representative of those in west-central Florida. The old Tampa well field is inactive and has several wells completed in the Upper Floridan aquifer.

\section{Purpose and Scope}

This report presents the results of a study to evaluate the hydrogeology of a carbonate aquifer system in west-central Florida using photolineament analysis, geophysical surveys, test drilling, rock-core analyses, aquifer tests, and tracer tests. The type and distribution of secondary porosity in the Upper Floridan aquifer at the test site is described in this report. Areas of contribution to hypothetical wells open to the Upper Floridan aquifer are delineated using a calibrated, steady-state, numerical, aquifer-simulation model of the ground-water flow system at the old Tampa well field and a particle-tracking program. Results of numerical modeling and particle-tracking are used to evaluate wellhead-protection strategies for west-central Florida.

\section{Description of the Study Site}

The old Tampa well field is a 40 -acre pasture $14 \mathrm{mi}$ east of the city of Tampa in northeastern Hillsborough County (fig. 1). The major drainage feature at the study site is Pemberton Creek, which flows west-northwest along the southern boundary of the site and drains into Lake Thonotosassa about $4 \mathrm{mi}$ from the site. Land surface ranges from about 67 to $75 \mathrm{ft}$ above sea level. 


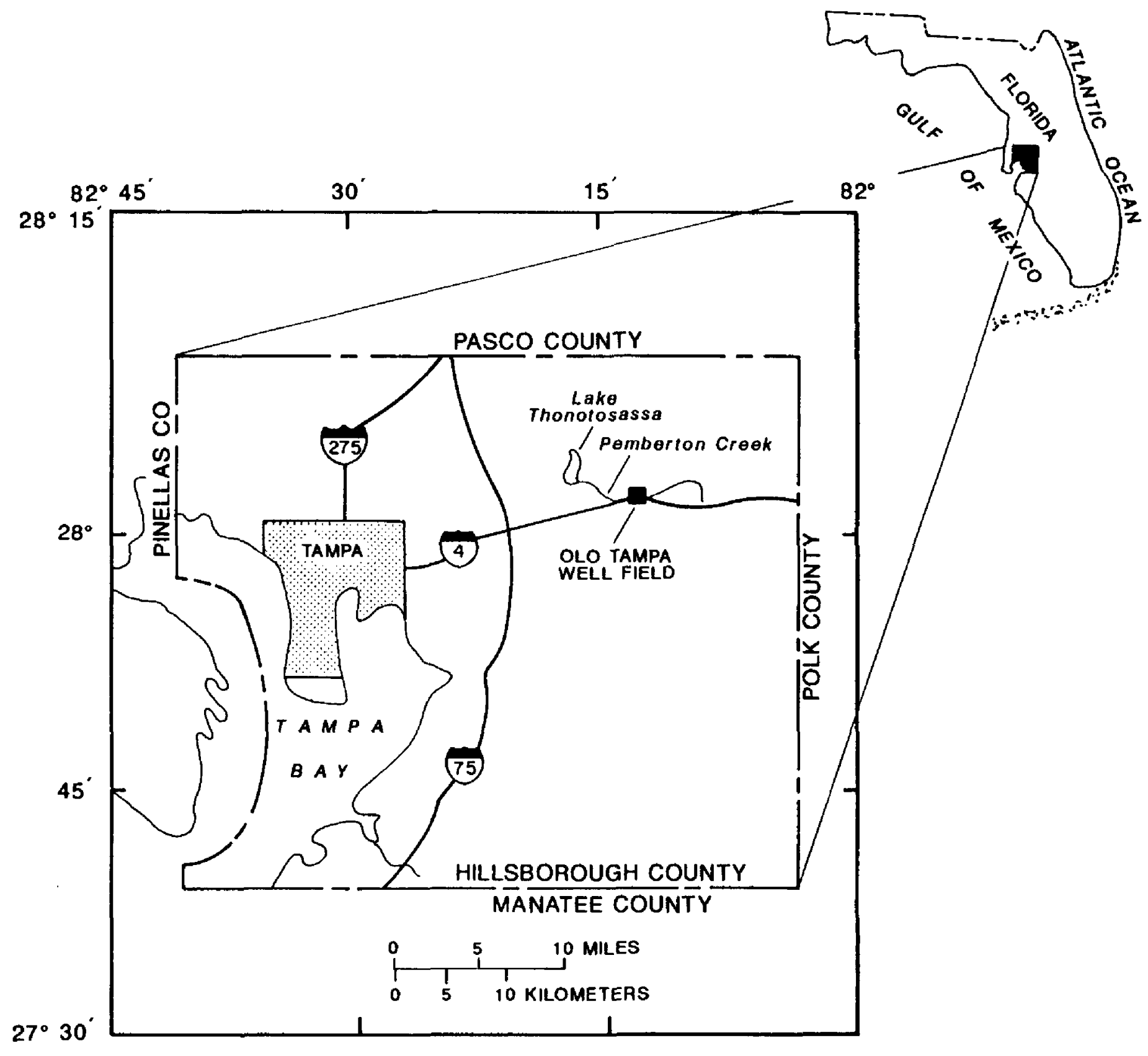

Figure 1. Location of the old Tampa well field.

Water levels in wells open to the Upper Floridan aquifer at the site ranged from 47 to $72 \mathrm{ft}$ above sea level for the period from 1958 to 1992 . Water levels typically fluctuated about $10 \mathrm{ft}$ between the wet and dry seasons. The site was evaluated for possible use as a well field by the City of Tampa, who owns the property, but was never used.

Rainfall in Hillsborough County usually occurs between May and October, and a pronounced dry season occurs between October and May. Average annual rainfall is about $50.8 \mathrm{in}$., but has varied from 32.0 to 76.6 in. since 1900 (Southwest Florida Water Management District, 1988). Ground-water use in northeastern Hillsborough County varies seasonally; the greatest demand is for irrigation of strawberries during the dry season. Intense pumping also occurs during short periods of freezing temperatures to protect crops from frost damage.

\section{Previous Investigations}

Results of previous investigations of the study area are documented in reports published by the USGS, the SWFWMD, the Florida Geological Survey, and publications in technical journals. Reports of investigations by the USGS that present hydrogeologic data for the study area include those by Sinclair $(1973 ; 1982)$, Ryder and others (1980), Wolansky and Corral (1985), and Miller (1986). The USGS reports that present data on ground-water tracer studies include reports by Reeder and others (1976) and Mull and others (1988). Vecchioli and others (1989) presented an evaluation of the methodology for delineation of wellhead-protection zones in west-central Florida. McDonald and Harbaugh (1988) documented the USGS modular ground-water flow model (MODFLOW), and Pollock (1989) documented a particle-tracking program (MODPATH) 
that uses the output of MODFLOW to calculate ground-water pathlines and time of travel.

Publications of the SWFWMD that present hydrogeologic data for the site include reports by Gilboy (1985), Jones (1985), Bengtsson and others (1986), and a ground-water resource availability inventory for Hillsborough County (Southwest Florida Water Management District, 1988). Bengtsson and others (1986) developed a numerical aquifer-simulation model of the Upper Floridan aquifer for the general vicinity of the study site.

Several FGS reports include information about the test site. Menke and others (1961) described the hydrology of Hillsborough County and presented geologic data, well-construction records, and aquifer-test data for the old Tampa well field. Scott (1988) redefined the Miocene sediments of Florida in that the Hawthorn Formation and Tampa Limestone of previous works were assigned group and member status, respectively. Andrews (1990) presented a map of the transmissivity and well yields of the Upper Floridan aquifer in Florida.

Recent papers in technical journals have presented the concept of ground-water flow in doubly porous aquifers, the characteristics of solute transport in aquifers, and the use of particle-tracking programs to delineate areas of wellhead-protection. Hickey (1984) described a simple test to check the validity of the assumption of Darcian flow in an aquifer. Smith and Vaughan (1985) presented the results of aquifer withdrawal tests in nonradial flow regimes. Gordon (1986) discussed the dependency of effective porosity on fracture continuity. Moench (1989) presented a Laplace transform solution for aquifer tracer testing that can be used to determine longitudinal dispersivity and effective porosity of a uniformly porous aquifer. Sabatini and Austin (1991) discussed the adsorption characteristics of fluorescent dyes used as groundwater tracers. Bair and others (1991) and Buxton and others (1991) presented the results of particle-tracking analyses of ground-water flow.

\section{Approach}

The study was organized into four phases of investigation: (1) surface and borehole geophysical surveys, (2) exploratory drilling and aquifer testing, (3) numerical modeling, and (4) tracer testing and particle tracking. Ground-penetrating radar (GPR) and electromagnetic (EM) surface geophysical surveys were performed to detect subsurface cavities, fracture zones, and other karst features in the Upper Floridan aquifer. Borehole geophysical surveys were performed in the Upper Floridan aquifer wells to correlate hydrogeologic units across the site. Ten shallow wells were installed to determine the thickness and composition of the unconsolidated surficial sediments. Analyses of rock cores from the Upper Floridan aquifer and the results of aquifer tests and tracer tests were used to estimate the hydraulic properties of the Upper Floridan aquifer. A numerical aquifer-simulation model of the site was calibrated using the results of the aquifer withdrawal tests. Water movement in the Upper Floridan aquifer was measured using fluorescent dye and table salt as tracers. A particle-tracking program was used to simulate ground-water travel times measured with tracers and to estimate ground-water travel times and flow path in the matrix of the karstic Upper Floridan aquifer for different combinations of pumped well(s), withdrawal rates, pumped interval within the aquifer, and well placement. The results of the particle-tracking simulations were used to evaluate wellhead-protection strategies for west-central Florida.

\section{Acknowledgments}

The author thanks the City of Tampa for allowing access to the site, the West Coast Regional Water Supply Authority, and Schreuder and Davis, Inc., for supplying geophysical logs of Upper Floridan aquifer wells at the old Tampa well field, drilling a 400-ft deep test well, and providing samples of rock cores collected from the Upper Floridan aquifer. The author also thanks Mark Stewart, Department of Geology, University of South Florida; Warren Hogg, West Coast Regional Water Supply Authority; and Cathleen Beaudoin and Glen Rubis, Schreuder and Davis, Inc., for their suggestions concerning the hydrogeology of the old Tampa well field.

\section{REGIONAL HYDROGEOLOGIC SETTING}

The lithology, structure, and geologic history of the sediments underlying Hillsborough County control the movement of ground water in the area. The geology of southwest Florida is known from studies of formations exposed at land surface, from examination of drill cuttings and cores, and from borehole surveys. Hillsborough County lies within the Florida Plateau, a structurally stable, partially submerged, carbonate platform 
overlain by deposits of Tertiary and Cretaceous age having a gentle homoclinal dip to the south-southwest (Southwest Florida Water Management District, 1988). The thickness of the sediments underlying Hillsborough County ranges from less than $8,000 \mathrm{ft}$ in the northeastern part of the county to more than $13,000 \mathrm{ft}$ in the southwestern part (Applin, 1951). These sediments were deposited on rhyolite and volcanic agglomerates (Applin, 1951) and range in age from Late Cretaceous to Holocene. These sediments are subdivided into three facies: (1) unconsolidated sand, clay, and marl of middle Miocene and younger age; (2) limestone and dolomites of early Miocene to late middle Eocene age; and (3) gypsiferous limestone and dolomites of early middle Eocene and older age. Facies 2 encompasses the Upper Floridan aquifer, and facies 1 and 3 constitute the overlying and underlying confining units and aquifers, respectively.

The ground-water system in Hillsborough County (fig. 2) consists of three distinct hydrogeologic units: (1) the surficial aquifer system; (2) the intermediate confining unit; and (3) the Floridan aquifer system (Southeastern Geological Society, 1986). The surficial aquifer system is the permeable hydrogeologic unit

\begin{tabular}{|c|c|c|c|c|}
\hline Series & $\underset{\substack{\text { Stratigrzphic } \\
\text { unft }}}{ }$ & $\begin{array}{l}\text { General } \\
\text { lithology }\end{array}$ & $\begin{array}{l}\text { Eydrogeologic } \\
\text { unit }\end{array}$ & $\begin{array}{c}\text { Approximate } \\
\text { thickness at } \\
\text { study site } \\
\text { (feet) }\end{array}$ \\
\hline $\begin{array}{l}\text { Holocene } \\
\text { and } \\
\text { Pleistocene }\end{array}$ & Surficial sands & $\begin{array}{l}\text { Sand and beach } \\
\text { deposits }\end{array}$ & $\begin{array}{l}\text { Surficial aquifer } \\
\text { system }\end{array}$ & $10-25$ \\
\hline Pliocene & $\begin{array}{l}\text { Bone Valley } \\
\text { Formation }\end{array}$ & Sand and clay & \multirow{3}{*}{$\begin{array}{l}\text { Intermediate } \\
\text { confining unit }\end{array}$} & \multirow{3}{*}{$10-40$} \\
\hline \multirow[t]{2}{*}{ Miocene } & $\begin{array}{l}\text { Hawthorn } \\
\text { Group }\end{array}$ & $\begin{array}{l}\text { Phosphatic } \\
\text { sand, clay, } \\
\text { and marl }\end{array}$ & & \\
\hline & $\begin{array}{l}\text { Tampa } \\
\text { Member }\end{array}$ & $\begin{array}{l}\text { Limestone, } \\
\text { sandy, clay }\end{array}$ & & \\
\hline Oligocene & $\begin{array}{l}\text { Suwannee } \\
\text { Limestone }\end{array}$ & $\begin{array}{l}\text { Limestone, } \\
\text { fossiliferous }\end{array}$ & \multirow{3}{*}{\begin{tabular}{l|l} 
F & \\
L & \\
0 & \\
$R$ & Upper \\
$I$ & Floridan \\
$D$ & aquifer \\
A &
\end{tabular}} & \multirow{3}{*}{1,100} \\
\hline \multirow{5}{*}{ Eocene } & $\begin{array}{l}\text { Ocala } \\
\text { Limestone }\end{array}$ & $\begin{array}{l}\text { Limestone, } \\
\text { chalky, } \\
\text { foraminiferal }\end{array}$ & & \\
\hline & \multirow[t]{2}{*}{$\begin{array}{l}\text { Avon Park } \\
\text { Formation }\end{array}$} & \multirow{2}{*}{$\begin{array}{l}\text { Limestone, } \\
\text { dolomite, } \\
\text { gypsum }\end{array}$} & & \\
\hline & & & \multirow{2}{*}{\begin{tabular}{l|l} 
I & Middle \\
F & confining \\
E & unit \\
R &
\end{tabular}} & \\
\hline & \multirow{2}{*}{$\begin{array}{l}\text { Oldsmar } \\
\text { Formation }\end{array}$} & \multirow{2}{*}{$\begin{array}{l}\text { Dolomite, } \\
\text { limestone, } \\
\text { gypsum }\end{array}$} & & 400 \\
\hline & & & \multirow{2}{*}{\begin{tabular}{l|l} 
& Lower \\
S & Floridan \\
$Y$ & aquifer \\
$S$ & \\
$T$ &
\end{tabular}} & \multirow{2}{*}{1,800} \\
\hline \multirow[t]{2}{*}{ Paleocene } & \multirow[t]{2}{*}{$\begin{array}{r}\text { Cedar Keys } \\
\text { Formation }\end{array}$} & \multirow{2}{*}{$\begin{array}{l}\text { Dolomite, } \\
\text { limestone, } \\
\text { gypsum, and } \\
\text { anhydrite }\end{array}$} & & \\
\hline & & & $M \mid \begin{array}{c}\text { Sub-Floridan } \\
\text { confining unit }\end{array}$ & $?$ \\
\hline \multicolumn{5}{|c|}{$\begin{array}{l}\text { 2Based on nomenclature of Southeastern Geological Society ( } 1986 \text { ). } \\
3 \text { Thickness at study site estimated from data collected during onsite drilling } \\
\text { d from Miller (1986), } \\
4 \text { Total thickness of the sub-Floridan confining unit beneath Hillsborough Count } \\
\text { not known. }\end{array}$} \\
\hline
\end{tabular}

Figure 2. Generalized hydrogeologic framework of Hillsborough County. 
exposed at land surface and includes unconsolidated to poorly indurated clastic sediments; it also can include indurated carbonate rocks other than those of the Floridan aquifer system. The intermediate confining unit includes interbedded sand, clay, and marl that lie between, and collectively retard the exchange of water between, the overlying surficial aquifer system and the underlying Floridan aquifer system. The intermediate confining unit thickens in southern Hillsborough County and permeable beds within it locally constitute aquifers (Vecchioli and others, 1989). The Floridan aquifer system includes all or part of the Paleocene to early Miocene Series. The top of the aquifer system generally coincides with the absence of clastics and with the top of the vertically persistent permeable carbonate section. In peninsular Florida, the base of the Floridan aquifer system coincides with anhydrite beds that lie near the top of the Cedar Keys Formation.

The Floridan aquifer system is divided into the Upper and Lower Floridan aquifers in southwestern Florida by a middle confining unit of low permeability (Miller, 1986). The Upper Floridan aquifer can be further subdivided based on permeability. Two distinct water-bearing zones have been described by the Southwest Florida Water Management District (1988). A shallow permeable zone in the aquifer is near land surface in northern Hillsborough County and is about $200 \mathrm{ft}$ deep in the southern part of the county. The most permeable layers within this shallow zone occur at the contacts between the Tampa Member and the Suwannee Limestone and the contact between the Suwannee Limestone and the Ocala Limestone (Southwest Florida Water Management District, 1988). The middle to lower part of the Ocala Limestone acts as a semiconfining unit between the upper and lower permeable zones. The deep, permeable zone of the Upper Floridan aquifer consists of fractured dolomite within the Avon Park Formation and ranges in depth from about 500 to $1,200 \mathrm{ft}$ below land surface from northern to southern Hillsborough County (Southwest Florida Water Management District, 1988).

\section{HYDROGEOLOGY OF THE OLD TAMPA WELL FIELD}

The hydrogeology of the ground-water flow system at the old Tampa well field was determined by test drilling, surface and borehole geophysical surveys, analysis of rock cores, and aquifer tests. Surface geophysical surveys were used to investigate the hydrogeologic significance of photolineaments at the old Tampa well field. Borehole geophysical surveys were used to determine the type and distribution of porosity and permeability in the Upper Floridan aquifer and to correlate geologic and hydrogeologic units between wells. The hydraulic coefficients of the Upper Floridan aquifer were estimated using rock-core analyses and aquifer tests.

\section{Well Network}

Twenty-three wells have been installed at the old Tampa well field (fig. 3), 13 of which are completed in the Upper Floridan aquifer (table 1). Seven 4-in.-diameter and two 16-in.-diameter wells were drilled in 1957 by the City of Tampa in an attempt to locate a water supply. These wells were completed with casing set from 39 to $74 \mathrm{ft}$ below land surface and ranged in depth from 250 to $800 \mathrm{ft}$. Geophysical logging in 1990 indicated that the borehole in well 23 was blocked at $92 \mathrm{ft}$ below land surface, and well 22 was blocked at $412 \mathrm{ft}$ below land surface. Subsequent soundings with a weighted line, however, indicated that both boreholes were open to the reported depths of 256 and $800 \mathrm{ft}$, respectively. The West Coast Regional Water Supply Authority (WCRWSA) initiated the drilling of four Upper Floridan aquifer wells at the site in March 1990: (1) well 15A; (2) the Ocala monitor well (OMW); (3) the Avon Park monitor well (APMW); and (4) the Avon Park production well (APPW). The WCRWSA also modified well 22 by reaming it to $800 \mathrm{ft}$ and setting additional casing to $480 \mathrm{ft}$ below land surface. All Upper Floridan aquifer wells at the site are completed with open-hole construction. A trailer-mounted power auger rig was used during this study to install ten 1.25-in.-diameter wells (table 1) in the unconsolidated sediments. Four wells were completed in the surficial aquifer system and six wells were completed in the intermediate confining unit.

\section{Geophysical Surveys}

Surface and borehole geophysical methods were used to collect geologic and hydrologic information about the subsurface at the old Tampa well field. Surface geophysical methods included GPR and EM surveys. Borehole geophysical logs were run in all accessible wells (table 2), and borehole video tapes were made of six of the Upper Floridan aquifer wells at the site (appendix). 


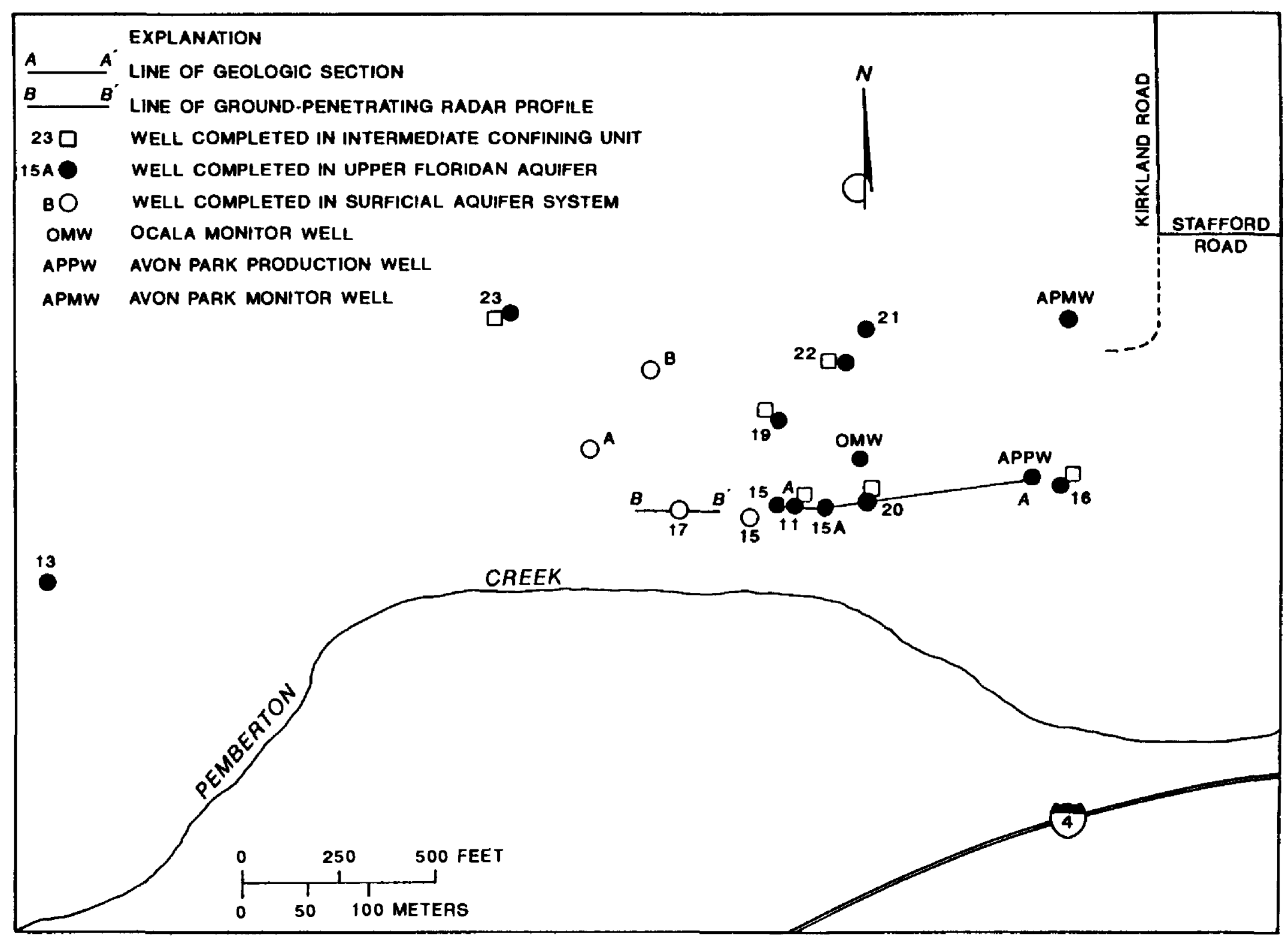

Figure 3. Locations of wells at the old Tampa well field.

The GPR surveys used the reflection of a 10- to $1,000-\mathrm{MHz}$ energy pulse to map subsurface layers. The depth of investigation is generally less than $100 \mathrm{ft}$ and is limited by many factors, including signal frequency and lithology. The EM surveys used an induced EM field to measure contrasts in the electrical conductance of subsurface material and respond to good conductors at shallow depths. The depth of investigation of an EM survey is limited by instrument power, interferences such as power lines and underground cables, and attenuation of the signal by good electrical conductors at shallow depths. The maximum depth of investigation varies with instrument and power source, but usually is less than $300 \mathrm{ft}$ with portable hand units. Very low frequency EM techniques that use 5- to $25-\mathrm{kHz}$ radio transmissions to induce the EM field, as well as high frequency techniques that use a paired transmitterreceiver coil system to induce the EM field, were used to perform geophysical surveys at the site.
Surface geophysical surveys were used to study the hydrogeologic significance of photolinear traces at the test site. Four photolineaments in the vicinity of the old Tampa well field (fig. 4) were mapped by Mark T. Stewart (University of South Florida, written commun., 1990). Photolineaments have been linked to fracture zones in the Upper Floridan aquifer in Florida by Vernon (1951) and to faults by Culbreth (1988). Fracture zones and faults are believed to influence ground-water movement, stream orientation, sinkhole development, and water quality.

Profiling of GPR across photolinear traces A, B, C, and $\mathrm{D}$ did not detect any change in the subsurface structure near the photolineaments. It is possible that the source of the photolineaments lies below the depth of penetration of the radar signal. The GPR record in the vicinity of shallow well 17 (fig. 3), however, indicated sloping reflectors. These are interpreted as sediments draped over a collapse feature (fig. 5). This 
Table 1. Construction data for wells at the old Tampa well field

[Depth is well depth below land surface; casing is casing depth below land surface. LSD, altitude of land surface, in feet above sea level, rounded to the nearest foot; OMW, Ocala monitor well; APMW, Avon Park Monitor well; APPW, Avon Park production well]

\begin{tabular}{|c|c|c|c|c|c|c|c|c|c|c|c|}
\hline \multicolumn{4}{|c|}{ Surficial aqulfer system } & \multicolumn{4}{|c|}{ Intermediate confining unlt } & \multicolumn{4}{|c|}{ Upper Floridan aquifer } \\
\hline $\begin{array}{c}\text { Well } \\
\text { number } \\
\text { (fig. 3) }\end{array}$ & $\begin{array}{l}\text { Depth } \\
\text { (feet) }\end{array}$ & $\begin{array}{c}\text { Casing } \\
\text { (feet }\end{array}$ & LSD & $\begin{array}{c}\text { Well } \\
\text { number } \\
\text { (fig. 3) }\end{array}$ & $\begin{array}{l}\text { Depth } \\
\text { (feet) }\end{array}$ & $\begin{array}{c}\text { Casing } \\
\text { (feet) }\end{array}$ & LSD & $\begin{array}{c}\text { Well } \\
\text { number } \\
\text { (fig. 3) }\end{array}$ & $\begin{array}{l}\text { Depth } \\
\text { (feet) }\end{array}$ & $\begin{array}{c}\text { Casing } \\
\text { (feet) }\end{array}$ & LSD \\
\hline 15 & 11.2 & 1.2 & 69 & 11 & 26.5 & 6.5 & 70 & 11 & 1750 & 74 & 70 \\
\hline 17 & 17.0 & 7.0 & 70 & 16 & 31.0 & 11.0 & 74 & 13 & 345 & 64 & 68 \\
\hline A & 15.2 & 5.2 & 67 & 19 & 23.6 & 3.6 & 72 & 15 & 415 & 67 & 70 \\
\hline \multirow{10}{*}{$\mathbf{B}$} & 9.0 & 0.0 & 72 & 20 & 30.0 & 0.0 & 70 & $15 \mathrm{~A}$ & 410 & 58 & 70 \\
\hline & & & & 22 & 40.0 & 20.0 & 74 & 16 & 250 & 50 & 74 \\
\hline & & & & 23 & 20.5 & 10.5 & 71 & 19 & 400 & 78 & 72 \\
\hline & & & & & & & & 20 & 2400 & 39 & 72 \\
\hline & & & & & & & & 21 & 256 & 92 & 74 \\
\hline & & & & & & & & 22 & 800 & 480 & 73 \\
\hline & & & & & & & & 23 & $3_{256}$ & 86 & 72 \\
\hline & & & & & & & & OMW & 450 & 250 & 75 \\
\hline & & & & & & & & APMW & 800 & 565 & 75 \\
\hline & & & & & & & & APPW & 800 & 550 & 75 \\
\hline
\end{tabular}

${ }^{1}$ Well plug set at 422 feet below land surface for tracer tests.

${ }_{3}^{2}$ Blocked at 340 feet below land surface; well plug set at 90 feet below land surface for shallow tracer test.

${ }^{3}$ Blocked at 92 feet below land surface.

Table 2. Types of borehole geophysical logs available for Upper Floridan aquifer wells at the old Tampa well field $[X$, logged under nonpumping conditions; $P$, logged under pumping conditions; OMW, Ocala monitor well; APMW, Avon Park monitor well; APPW, Avon Park production well]

\begin{tabular}{|c|c|c|c|c|c|c|c|c|c|c|c|}
\hline \multirow{2}{*}{$\begin{array}{c}\text { Well } \\
\text { numbar } \\
\text { (fig. 3) }\end{array}$} & \multirow{2}{*}{$\begin{array}{l}\text { Natural } \\
\text { gamma }\end{array}$} & \multirow[b]{2}{*}{ Caliper } & \multirow[b]{2}{*}{ Flow } & \multirow{2}{*}{$\begin{array}{c}\text { Electric } \\
\log \end{array}$} & \multicolumn{2}{|c|}{ Resistivity } & \multirow{2}{*}{$\begin{array}{l}\text { Acoustic } \\
\text { velocity }\end{array}$} & \multirow{2}{*}{$\begin{array}{l}\text { Temper- } \\
\text { ature }\end{array}$} & \multirow{2}{*}{$\begin{array}{l}\text { Gamma- } \\
\text { gamma } \\
\text { density }\end{array}$} & \multirow{2}{*}{$\begin{array}{l}\text { Neutron } \\
\text { porosity }\end{array}$} & \multirow[b]{2}{*}{ Video } \\
\hline & & & & & $\begin{array}{l}\text { Focused } \\
\text { (guard) }\end{array}$ & Fluid & & & & & \\
\hline 11 & $\mathrm{X}$ & $\mathrm{X}$ & $\mathrm{X}, \mathrm{P}$ & $\mathrm{X}$ & $\mathrm{X}$ & $X, P$ & $\mathrm{X}$ & $X, P$ & $\mathrm{X}$ & $\mathrm{X}$ & $\mathrm{X}$ \\
\hline 13 & $X$ & $\mathrm{X}$ & & $X$ & & $\mathrm{X}$ & & $\mathrm{X}$ & & & \\
\hline 15 & $\mathrm{X}$ & $\mathrm{X}$ & $\mathrm{X}, \mathrm{P}$ & $X$ & $\mathrm{X}$ & $\mathrm{X}, \mathrm{P}$ & $\mathrm{X}$ & $X, P$ & $X$ & $X$ & $X, P$ \\
\hline $15 \mathrm{~A}$ & $\mathrm{X}$ & $\mathrm{X}$ & $\mathrm{X}, \mathrm{P}$ & $\mathrm{X}$ & $\mathrm{X}$ & $X, P$ & $\mathrm{X}$ & $\mathrm{X}, \mathrm{P}$ & & & $\mathrm{X}$ \\
\hline 16 & $\mathrm{X}$ & $\mathrm{X}$ & & & $\mathrm{X}$ & & & $\mathrm{X}$ & & & \\
\hline 19 & $X$ & $X$ & & $X$ & & $X$ & & $X$ & & & \\
\hline 20 & $X$ & $\mathrm{X}$ & & $x$ & & $X$ & $\mathrm{X}$ & $\mathrm{X}$ & $\mathrm{X}$ & $\mathrm{X}$ & $\mathrm{X}$ \\
\hline 22 & $\mathrm{X}$ & $\mathrm{X}$ & $\mathrm{P}$ & & & $\mathrm{P}$ & & $\mathrm{P}$ & & & \\
\hline 23 & $\mathrm{X}$ & & & & & & & & & & \\
\hline OMW & & & $P$ & & & $X, P$ & & $X, P$ & & & $\mathrm{X}$ \\
\hline APMW & $\mathrm{X}$ & $X$ & $\mathrm{X}, \mathrm{P}$ & $\mathrm{X}$ & & $\mathrm{X}, \mathrm{P}$ & & $\mathrm{X}, \mathrm{P}$ & & & $\mathrm{X}$ \\
\hline APPW & $X$ & $X$ & $\mathrm{X}, \mathrm{P}$ & $X$ & & $\mathrm{X}, \mathrm{P}$ & & $\mathrm{X}, \mathrm{P}$ & & & \\
\hline
\end{tabular}




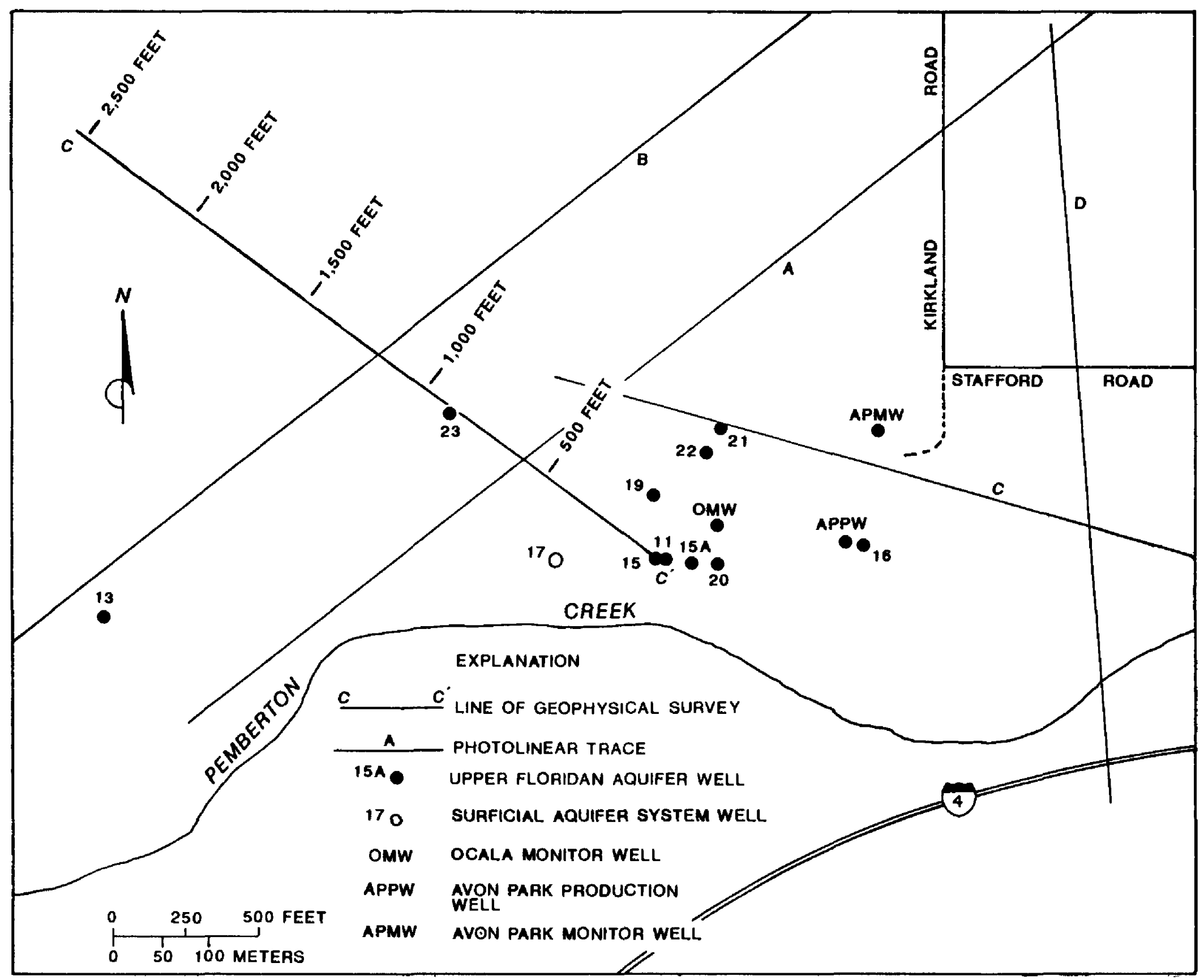

Figure 4. Locations of photolineaments and line of surface geophysical survey at the old Tampa well field.

interpretation is supported by a test boring at the location of shallow well 17 . The boring reached a depth of $310 \mathrm{ft}$ without penetrating limestone (Menke and others, 1961). The GPR profile shows that the surface of the water table is not depressed at the probable sinkhole, indicating poor hydraulic connection between the surficial aquifer system and the underlying Upper Floridan aquifer.

An alternating sequence of conductive and resistive anomalies was indicated by EM surveys across the traces of photolineaments $A$ and B, north-northwest of well 15 (fig. 6). A zone of limestone pinnacles and troughs is one hydrogeologic interpretation of the anomalies (Mark T. Stewart, University of South Florida, written commun., 1990). The photolineament northwest of the well field is interpreted as the surface expression of a fracture zone. Wells completed within a fracture zone are likely to respond to pumping in a non-Theis manner. No EM surveys of photolineaments $\mathrm{C}$ and $\mathrm{D}$ were performed.

Borehole geophysical and video logs were used to correlate geologic and hydrogeologic units between the Upper Floridan aquifer wells. The natural gamma, focused resistivity, and spontaneous potential logs and the lithologic descriptions of the material penetrated during drilling were used to determine formation boundaries based on the criteria described by Gilboy (1985). A geologic section (fig. 7) shows that the strata under the study site are nearly horizontal. The formations include the Tampa Member of the Hawthorn Group, the Suwannee Limestone, the Ocala Limestone, and the Avon Park Formation. Miocene and Pliocene sediments younger than the Tampa Member are not differentiated. 

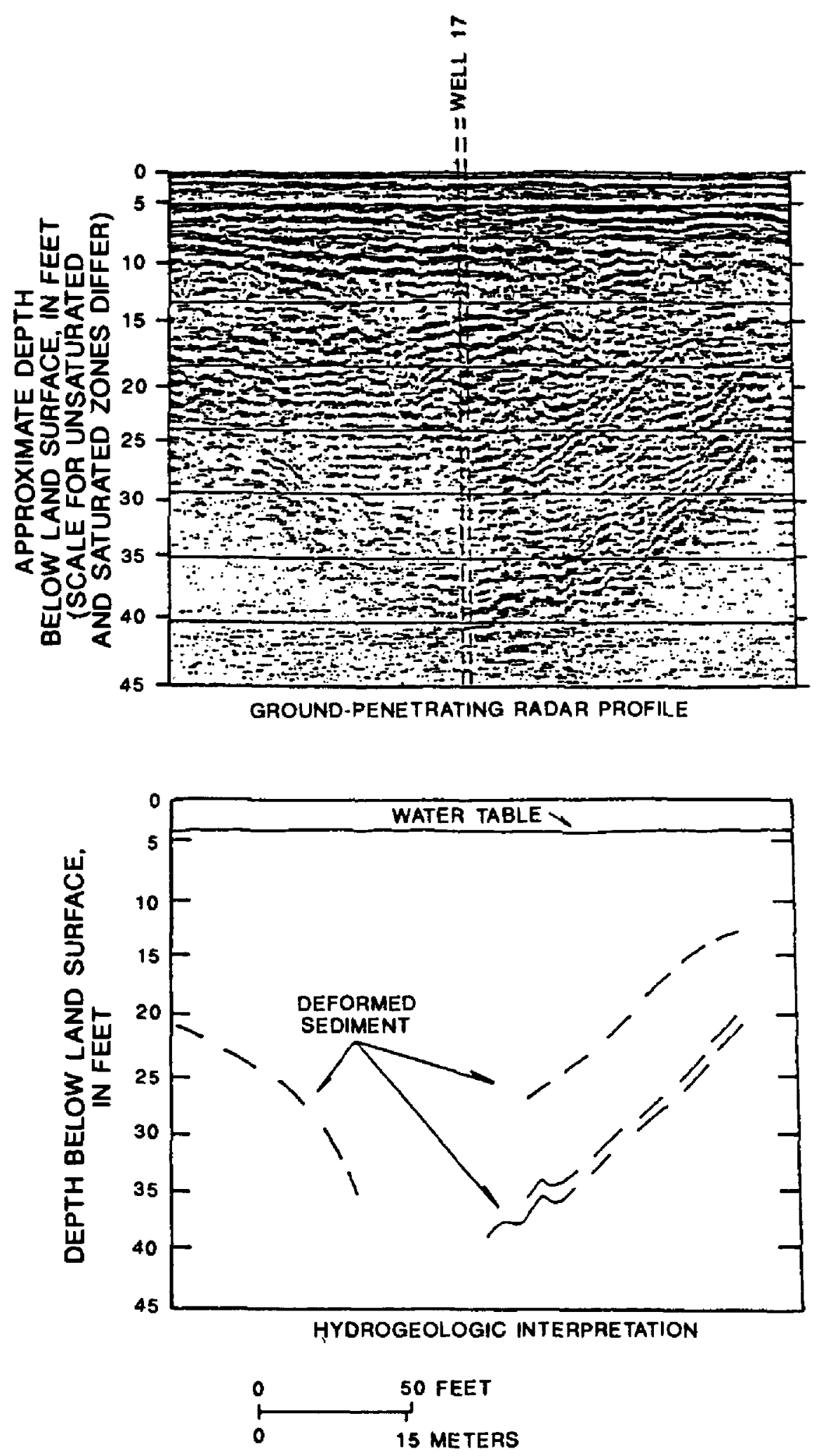

Figure 5. Ground-penetrating radar record near well 17 (fig. 3) and hydrogeologic interpretation.

Flowmeter and fluid resistivity logs were used to determine the depth intervals at which water enters wells and to define the distribution of permeable and semiconfining units in the Upper Floridan aquifer. Wells were pumped at rates of 300 to $1,000 \mathrm{gal} / \mathrm{min}$ during flowmeter logging (fig. 8). The flowmeter logs were normalized to compensate for borehole diameter. A zone of extensive borehole caving from 500 to $300 \mathrm{ft}$ below land surface was penetrated during the drilling of the Avon Park monitor well (fig. 8). The flowmeter $\log$ of this well could be inaccurate in this zone because the borehole diameter measurements are estimated.
This is the probable cause of the loss of flow indicated in this zone by the log for the Avon Park monitor well (fig. 8). The flowmeter log for well 15 indicates that about 50 percent of the water entering the well originates from the depth interval of 410 to $380 \mathrm{ft}$ below land surface, and about 45 percent of the water entering the well originates from the depth interval of 250 to $70 \mathrm{ft}$ below land surface (fig. 8). The flowmeter log of well $15 \mathrm{~A}$ indicates that about 25 percent of the water entering the well originates from the depth interval of 400 to $380 \mathrm{ft}$ below land surface, and about 70 percent of the water entering the well originates from the depth interval of 250 to $70 \mathrm{ft}$ below land surface. Additional flowmeter surveys in the Ocala monitor well and the Avon Park production well indicate that the strata from 425 to $550 \mathrm{ft}$ below land surface does not yield significant quantities of water to the wells, but the interval from 550 to $800 \mathrm{ft}$ below land surface does yield significant quantities (fig. 8).

The vertical distribution of effective secondary porosity in open boreholes at the study site was determined using techniques described by Safko and Hickey (1992). Apparent secondary porosity for a specified depth, identified using video logs (appendix), is considered to be effective if water enters the well at that depth. The identification of effective secondary porosity in well $15 \mathrm{~A}$ using borehole geophysical logs and video $\operatorname{logs}$ is illustrated in figure 9. The effective secondary porosity $\operatorname{logs}$ for wells $15,15 \mathrm{~A}$, and the Ocala monitor well were compared, and a conceptual log (fig. 10) was prepared to depict the approximate vertical distribution, and type, of effective secondary porosity, which has significant lateral extent within the upper $400 \mathrm{ft}$ of the Upper Floridan aquifer. Additional zones of effective secondary porosity probably exist at depths greater than those shown in figure 10 , but there is insufficient data from the study site to perform an analysis for these depths.

The descriptive terminologies used for porosity features are "fracture" and "vug", porosity. Fracture porosity is used in this report to describe cracks in the rocks that are caused by tectonic deformation. Vug porosity is used to describe pores that are large enough to be seen in a borehole television survey, and the term applies to both nonfabric selective porosity and to fabric selective porosity, such as moldic porosity.

The data indicate that the Upper Floridan aquifer at the old Tampa well field is a layered aquifer system with at least three permeable units. The first two permeable units constitute the shallow permeable zone and 
WELL 15

C

EM-34 SURVEY: $20 \mathrm{~m}$ HORIZONTAL COILS $C^{\prime}$
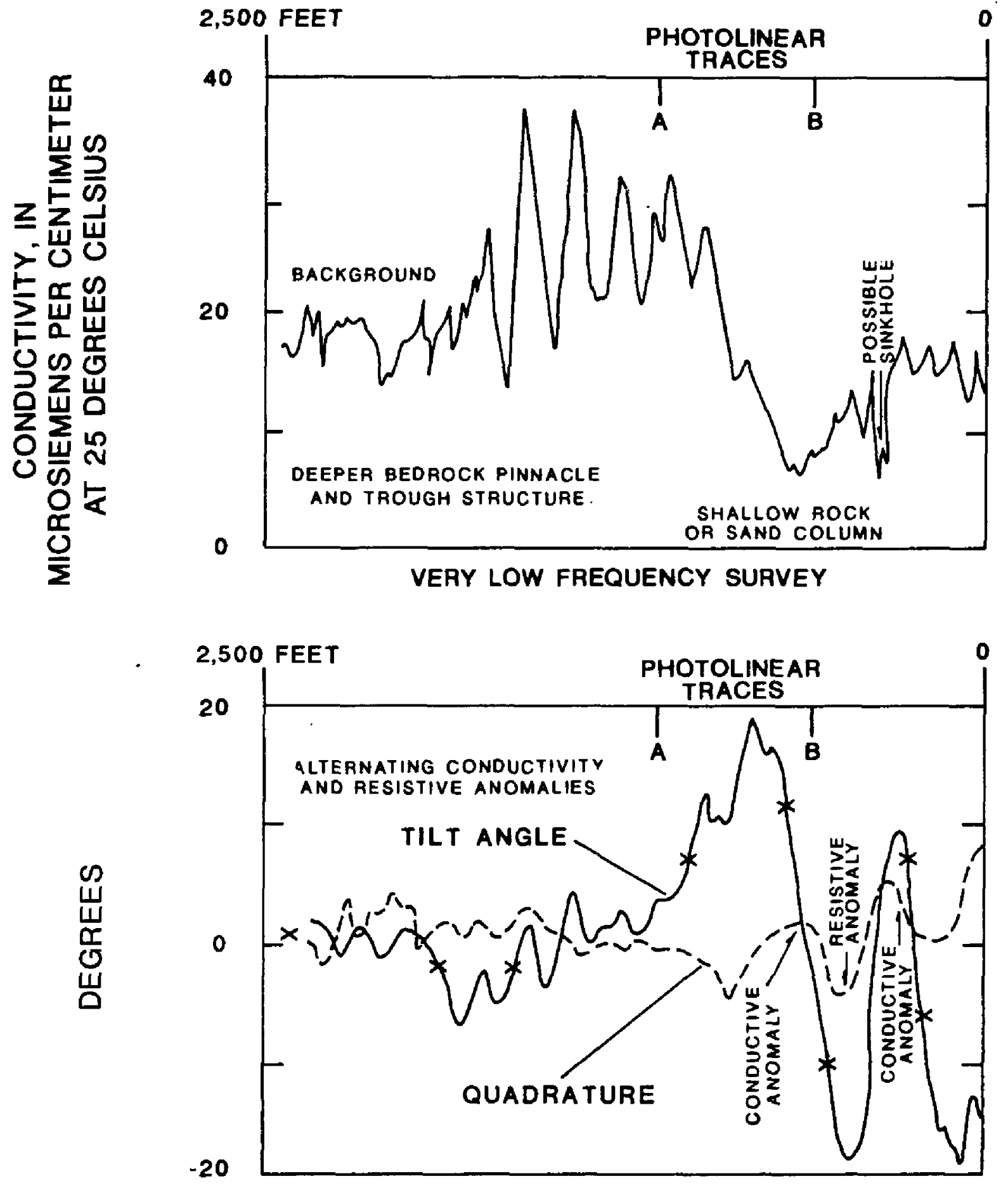

POSSIBLE HYDROGEOLOGIC INTERPRETATION

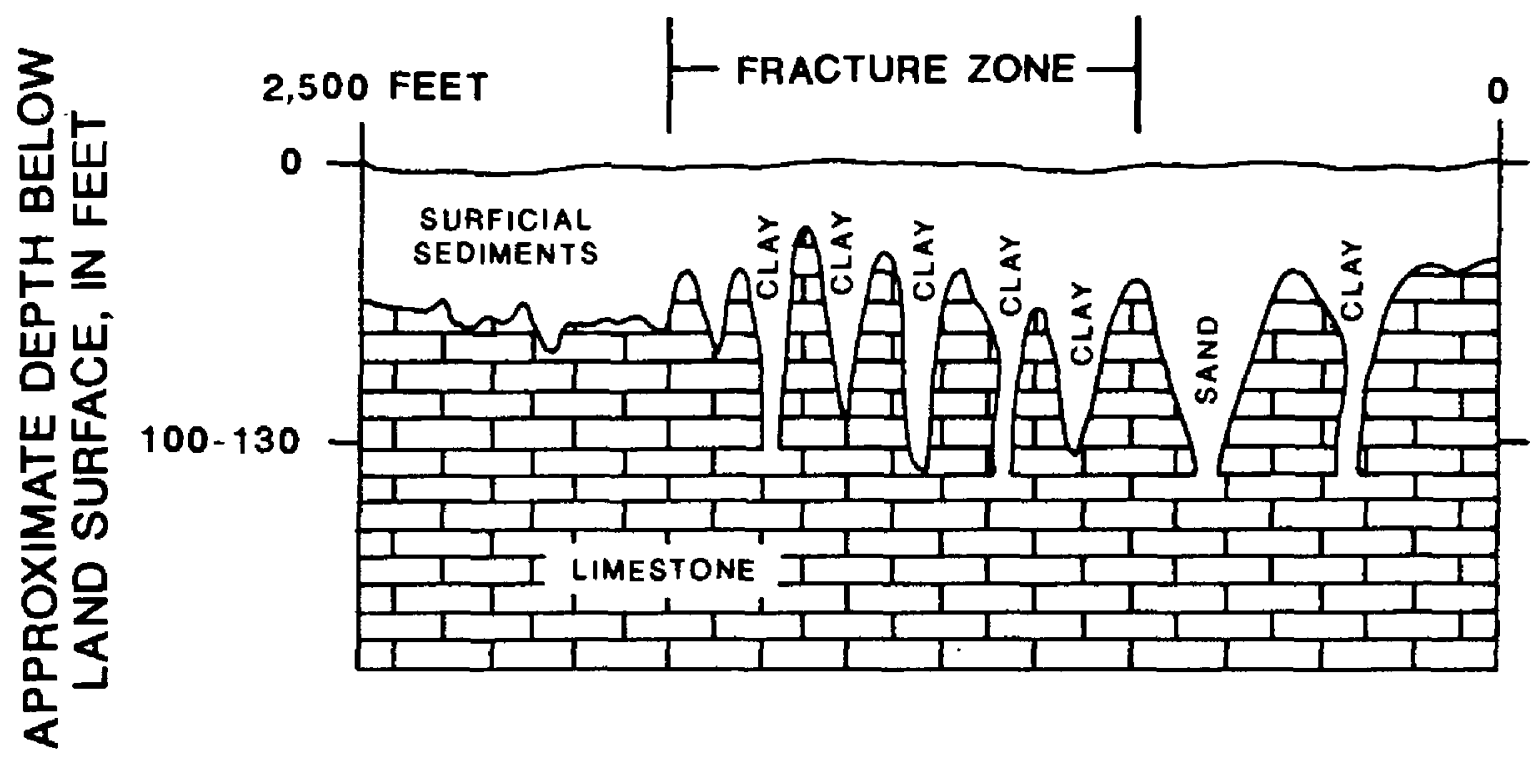

Figure 6. Electromagnetic geophysical records at the old Tampa well field and hydrogeologic interpretation. (See fig. 4 for location of section $C-C$.) 


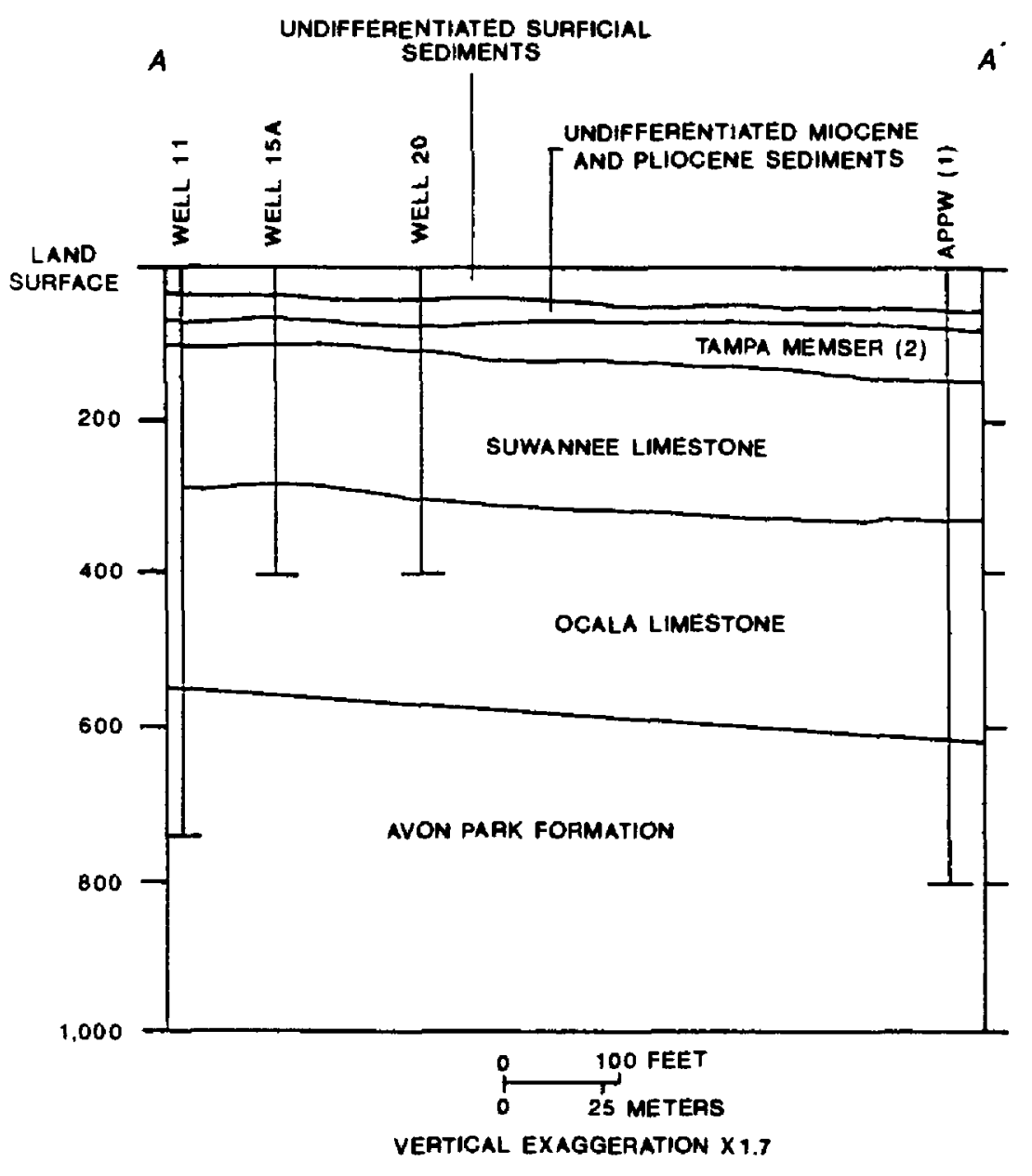

(1) AVON PARK PRODUCTION WELL

(2) NOMENCLATURE FROM SCOTT (1988)

Figure 7. Geologic section $A-A^{\prime}$ at the old Tampa well field. (See fig. 3 for location of section.) the third permeable unit corresponds to the deep permeable zone (Southwest Florida Water Management District, 1988). In this report, permeable units one, two, and three refer to the water-producing zones from about the top of the limestone to 250,380 to 410 , and 550 to $800 \mathrm{ft}$ below land surface, respectively, that were identified using flowmeter and fluid resistivity logs. Figure 10 indicates that zones of effective secondary porosity with significant lateral extent are layered throughout the upper $400 \mathrm{ft}$ of the Upper Floridan aquifer. Permeable units have little relation to formation boundaries. Therefore, the aquifer system is correctly conceptualized using hydrogeologic boundaries rather than formation boundaries.

\section{Hydrogeologic Units}

The surficial aquifer system at the old Tampa well field consists of fine to medium grained quartz sand that grades downward to marl and clay of the intermediate confining unit. Quartz sandstone cemented with clay also is present. Thickness of the surficial aquifer system ranges from less than 50 to more than $100 \mathrm{ft}$ and can be highly variable over short distances because of

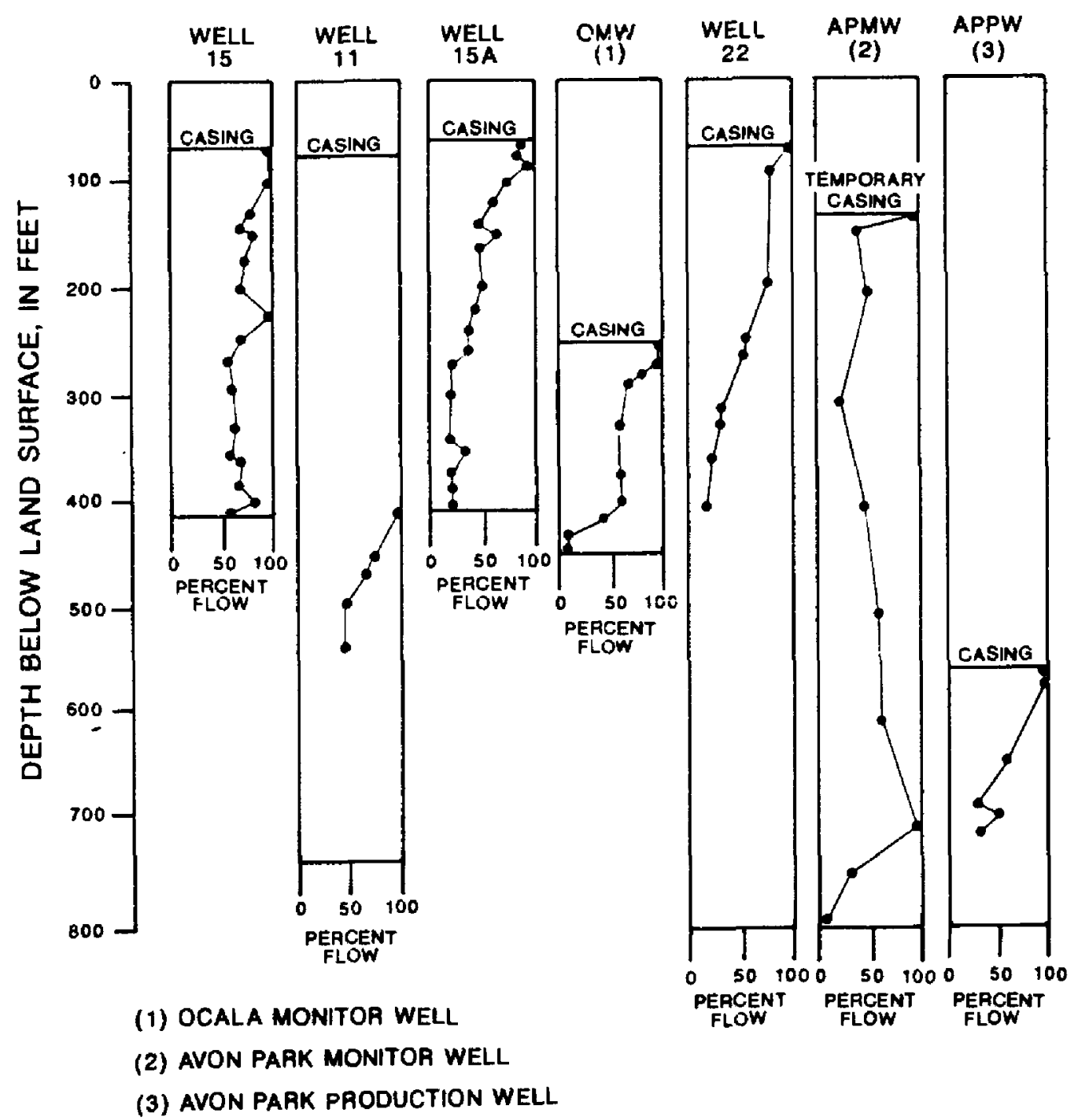

Figure 8. Flowmeter logs for wells at the Old Tampa well field, 1990. 


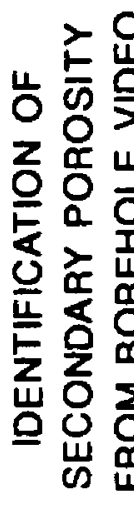
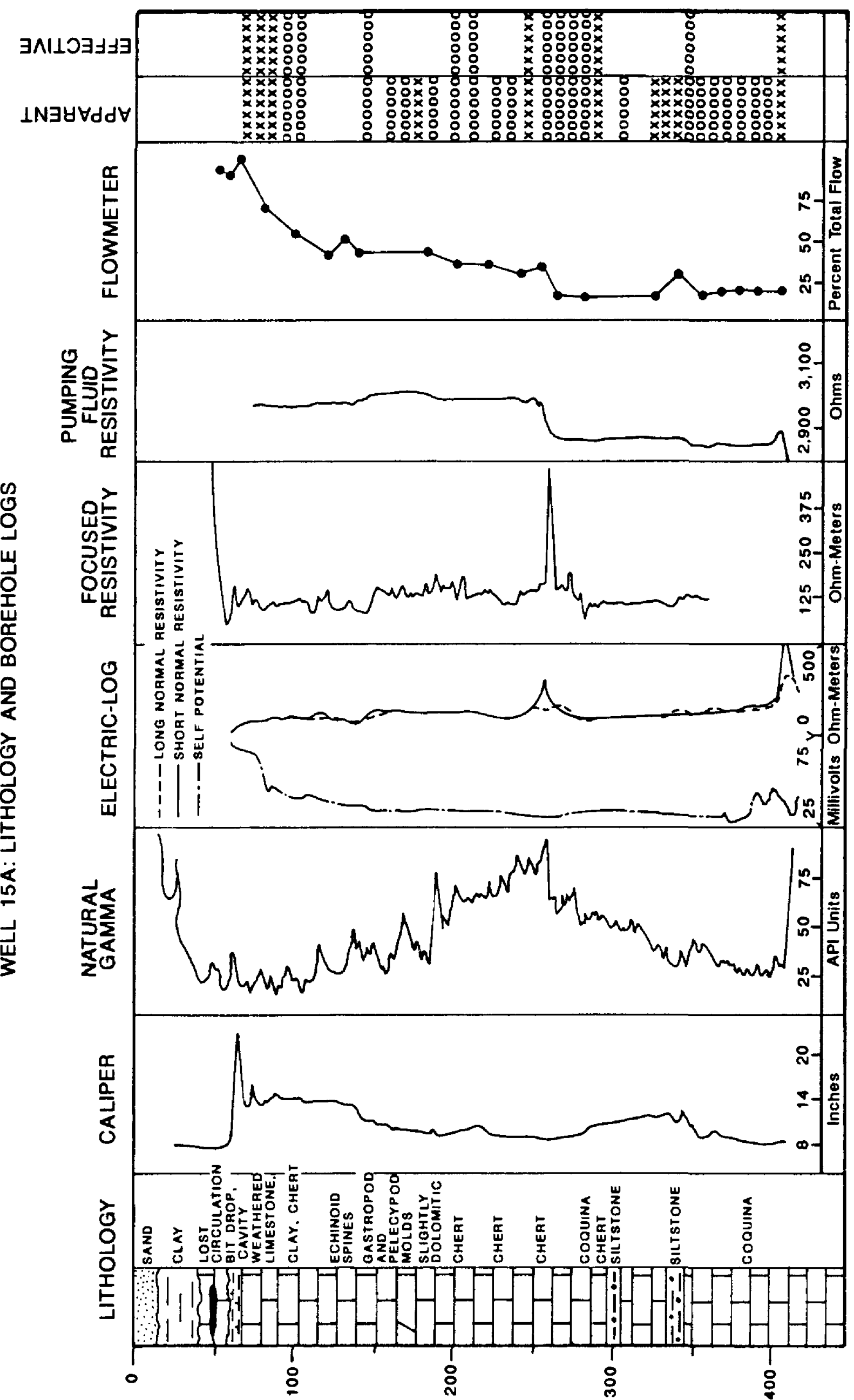

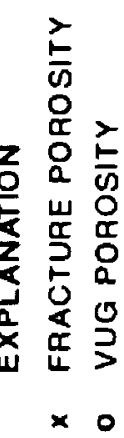




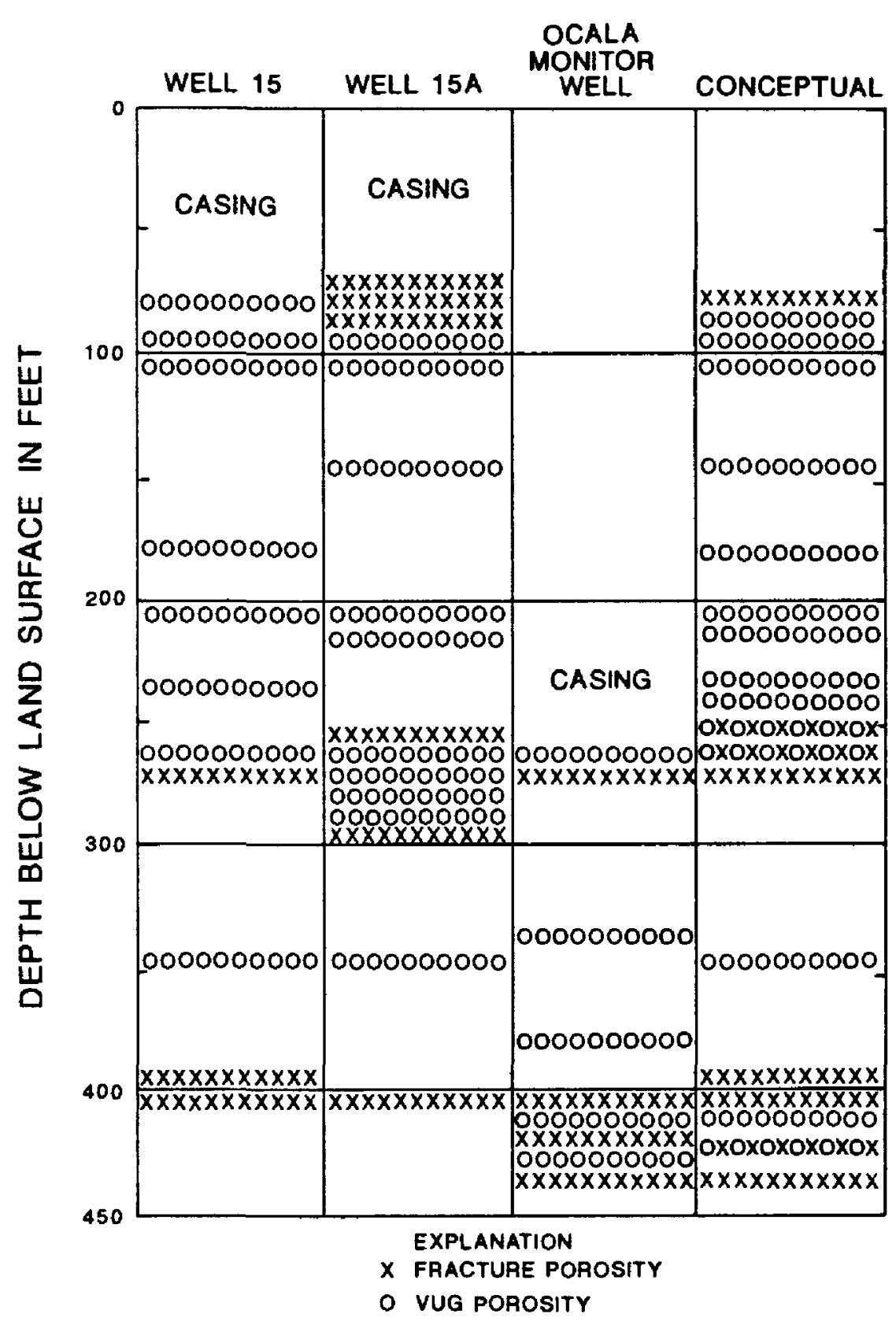

Figure 10. Effective secondary porosity logs for wells 15, $15 \mathrm{~A}$, and the Ocala monitor well and a conceptual log.

the irregular surface of the underlying limestone. The horizontal hydraulic conductivity of permeable units of the surficial aquifer system in Hillsborough County ranges from less than 1 to more than $100 \mathrm{ft} / \mathrm{d}$ and the storage coefficient ranges from 0.05 to 0.3 (Southwest Florida Water Management District, 1988). The average range of values of hydraulic conductivity is 5 to $25 \mathrm{ft} / \mathrm{d}$ (Freeze and Cherry, 1979) for the size and type of sediments at the study site.

The surficial aquifer system is underlain by the intermediate confining unit. The intermediate confining unit at the old Tampa well field is composed of 10 to $50 \mathrm{ft}$ of clay, sandy clay, and marl. Reported values of the leakance coefficient of the intermediate confining unit in southwest Florida range from 0.0001 to $0.001(\mathrm{ft} / \mathrm{d}) / \mathrm{ft}$ (Wolansky and Corral, 1985). A thickness map of the intermediate confining unit (fig. 11) was prepared using the well completion records of 67 wells within a 2-mi radius of the old Tampa well field. The thickness of the intermediate confining unit ranges from 10 to $60 \mathrm{ft}$ (fig. 11). The irregular shape of the contours indicates that the unit might have been deposited on a surface of variable elevation, or the unit was subjected to erosion after deposition, or both. The confinement of the underlying Upper Floridan aquifer could be highly variable because of the varying thickness and composition of the intermediate confining unit.

The surface of the Upper Floridan aquifer at the test site is irregular and is interpreted as a paleokarst surface. Test drilling and surface geophysical surveys support this interpretation. Limestone was first penetrated at considerably different depths in adjacent wells during drilling. The drilling $\log$ of well 11 indicates limestone at $43 \mathrm{ft}$ below land surface. A borehole drilled $125 \mathrm{ft}$ west of well 11 had not penetrated limestone at a depth of $140 \mathrm{ft}$. The borehole designated well 17 by Menke and others (1961) was drilled to $310 \mathrm{ft}$ below land surface without penetrating limestone. The middle confining unit of the Floridan aquifer system in the vicinity of the old Tampa well field has not been penetrated, but is estimated to be about $1,100 \mathrm{ft}$ below land surface (Ryder and others, 1980).

\section{Hydraulic Properties of the Upper Floridan Aquifer}

The hydraulic properties of the Upper Floridan aquifer at the old Tampa well field were estimated from published values, rock-core analyses, and aquifer tests and are summarized in table 3 . Estimates of the transmissivity of the Upper Floridan aquifer to a depth of $800 \mathrm{ft}$ range from 29,000 to $37,000 \mathrm{ft}^{2} / \mathrm{d}$. Estimates of the storage coefficient range from $5 \times 10^{-5}$ to $2 \times 10^{-3}$. Aquifer tests indicate that the aquifer is stratified, with the deeper rocks being more permeable than the shallow ones. For example, doubling the depth of well 15 increased the estimated transmissivity by a factor of about three (Menke and others, 1961). Doubling the depth of well 22 increased the estimated transmissivity by a factor of about four (Menke and others, 1961) or five (Wolansky and Corral, 1985).

Based on the reported compressibility of carbonates (Freeze and Cherry, 1979, p. 55), a storage coefficient range of $1.1 \times 10^{-4}$ to $1.1 \times 10^{-2}$ was calculated for the Upper Floridan aquifer at the study site. A simple method to estimate storage coefficients, as described by Lohman (1979, p. 53), yields a storage coefficient 


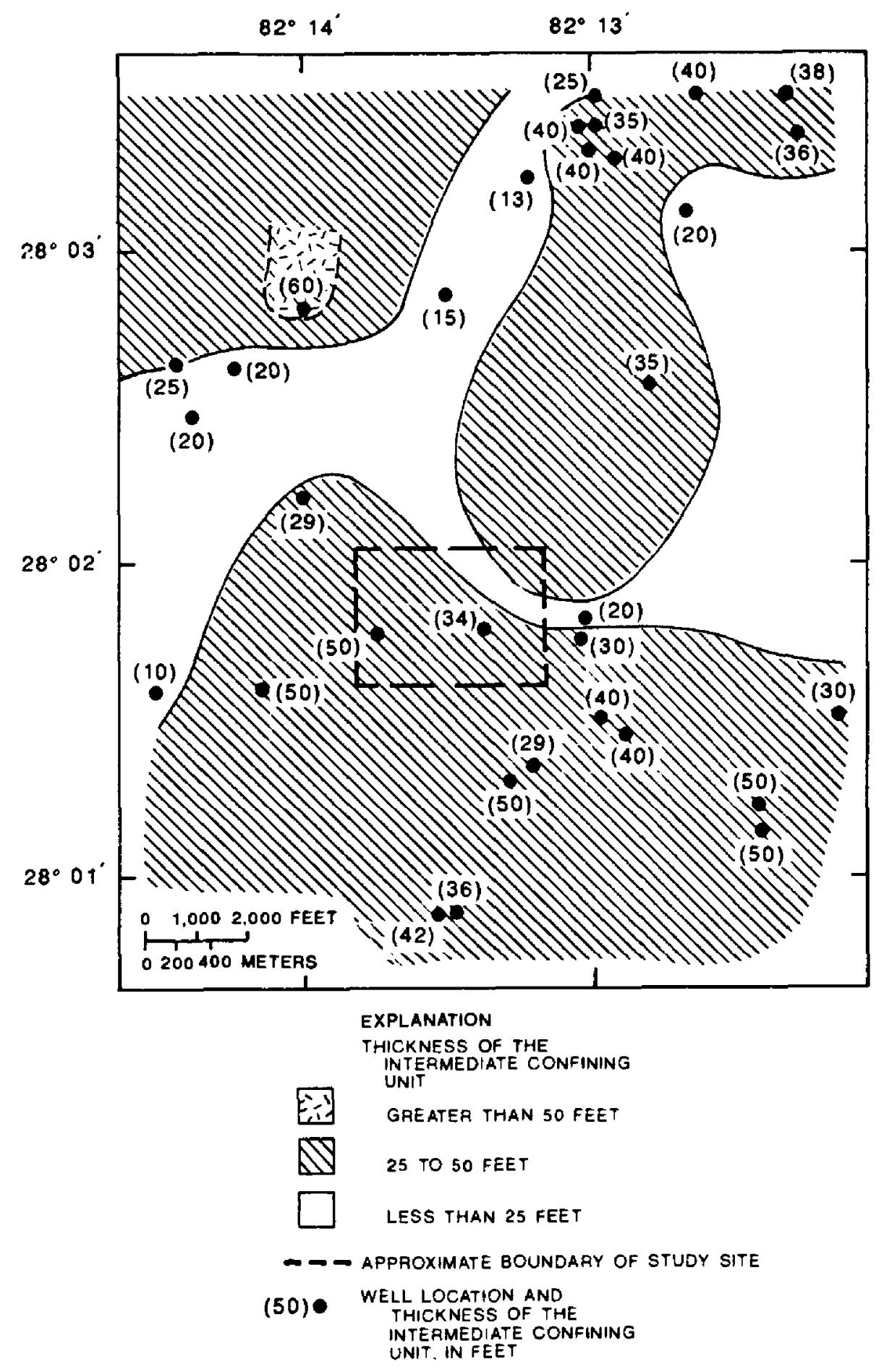

Figure 11. Thickness of the intermediate confining unit in the vicinity of the old Tampa well field. of $2 \times 10^{-3}$ for the depth interval from 70 to $250 \mathrm{ft}$ below land surface (permeable zone one), $4 \times 10^{-4}$ for the depth interval from 380 to $425 \mathrm{ft}$ below land surface (permeable zone two), and about $2.5 \times 10^{-3}$ for the depth interval from 550 to $800 \mathrm{ft}$ below land surface (permeable zone three). These estimates fall within the range of values estimated using the reported compressibility of carbonates.

\section{Rock-Core Analyses}

Analyses of rock cores in southwest Florida indicate the ratio of horizontal to vertical hydraulic conductivity reported for the Suwannee and Ocala Limestones in Hillsborough County spanned five orders of magnitude (table 4). At one site, this ratio varied by three orders of magnitude within a depth interval of 432 to $500 \mathrm{ft}$ below land surface in the Ocala Limestone. Reported values for effective porosity range from 17 to 46 percent for the Suwannee and Ocala Limestones in Hillsborough County. These data support the interpretation of the aquifer as a layered system.

Two 10-ft rock cores were collected at depths of 170 to 180 and 300 to $310 \mathrm{ft}$ below land surface during the drilling of well 15A. These depth intervals were sampled because they coincide with permeable unit one and the semiconfining unit separating permeable units one and two of the Upper Floridan aquifer. The core collected from 170 to $180 \mathrm{ft}$ below land surface was composed of fossiliferous, granular limestone with abundant visible porosity. The core collected from 300 to $310 \mathrm{ft}$ below land surface was composed of chalky, dense limestone with only minor visible porosity. Representative samples of the cores were analyzed to determine effective porosity and vertical and horizontal hydraulic conductivity (table 4 ).

Table 3. Reported hydraulic properties of the Upper Floridan aquifer at the old Tampa well field [ $\mathrm{ft} / \mathrm{d}$, foot per day; $\mathrm{ft}^{2} / \mathrm{d}$, foot squared per day; $(\mathrm{ft} / \mathrm{d}) / \mathrm{ft}$, foot per day per foot; APPW, Avon Park production well]

\begin{tabular}{ccccccc}
\hline $\begin{array}{c}\text { Pumped } \\
\text { well } \\
\text { (fig. 3) }\end{array}$ & $\begin{array}{c}\text { Open hole } \\
\text { interval of } \\
\text { pumped well } \\
\text { (feet) }\end{array}$ & $\begin{array}{c}\text { Hydraulic } \\
\text { conductivity } \\
\text { (ft/d) }\end{array}$ & $\begin{array}{c}\text { Transmissivity } \\
\left(\mathbf{f t}^{2} / \mathbf{d}\right)\end{array}$ & $\begin{array}{c}\text { Storage } \\
\text { coefficient }\end{array}$ & $\begin{array}{c}\text { Leakance } \\
\text { coefficient } \\
{[(\mathbf{f t} / \mathbf{d}) / \mathbf{f t}]}\end{array}$ & Source of data \\
\hline 15 & $68-227$ & 30 & 4,800 & 0.00005 & 0.004 & Menke and others $(1961)$ \\
15 & $68-413$ & 40 & 14,000 & .0003 & .0027 & Menke and others $(1961)$ \\
22 & $72-420$ & 20 & 7,000 & .0007 & .00013 & Menke and others $(1961)$ \\
22 & $72-800$ & 40 & 29,000 & .002 & .00027 & Menke and others $(1961)$ \\
22 & $72-810$ & 50 & 37,000 & .0015 & $<.00032$ & Wolansky and Corral (1985) \\
APPW & $550-800$ & 120 & 30,000 & .0023 & .00048 & Schreuder and Davis, Inc. (1991) \\
\hline
\end{tabular}


Table 4. Analyses of rock cores collected from the Upper Floridan aquifer in Hillsborough, Pasco, Pinellas, and Polk Counties, Florida

[ft, feet; ft/d, feet per day; NR, not reported; ---, no data]

\begin{tabular}{|c|c|c|c|c|c|c|c|}
\hline \multirow{2}{*}{ Formation } & \multirow{2}{*}{$\begin{array}{c}\text { Depth } \\
\text { (ft) }\end{array}$} & \multirow{2}{*}{ County } & \multicolumn{2}{|c|}{$\begin{array}{l}\text { Hydraulic } \\
\text { conductivity }\end{array}$} & \multirow{2}{*}{$\begin{array}{c}\text { Patio of } \\
\text { horizontal to } \\
\text { vertical hydraulic } \\
\text { conductivity } \\
\text { (dimensionless) }\end{array}$} & \multirow{2}{*}{$\begin{array}{l}\text { Effective } \\
\text { porosity } \\
\text { (pecent) }\end{array}$} & \multirow{2}{*}{ Source } \\
\hline & & & $\begin{array}{l}\text { Vertical } \\
\text { (ft/d) }\end{array}$ & $\begin{array}{c}\text { Horizontal } \\
(\mathrm{ft} / \mathrm{d})\end{array}$ & & & \\
\hline \multirow{3}{*}{ Ocala Limestone } & 360 & Pasco & 0.005 & 0.002 & 0.4 & 37 & $\mathrm{CH}_{2} \mathrm{M}$ Hill, Inc. (1990) \\
\hline & 400 & & .79 & .16 & .2 & 38 & $\mathrm{CH}_{2} \mathrm{M}$ Hill, Inc. (1990) \\
\hline & 450 & & .01 & .01 & 1.0 & 39 & $\mathrm{CH}_{2} \mathrm{M}$ Hill, Inc. (1990) \\
\hline Suwannee Limestone & 72 & Polk & .007 & .01 & 1.4 & 32 & Stewart (1966) \\
\hline \multirow[t]{3}{*}{ Ocala Limestone } & 269 & Polk & .12 & .134 & 1.1 & 44 & Stewart (1966) \\
\hline & 282 & & .16 & .16 & 1.0 & 27 & Stewart (1966) \\
\hline & 317 & & .27 & .54 & 2.0 & 44 & Stewart (1966) \\
\hline \multirow[t]{2}{*}{ Avon Park Formation } & 447 & Polk & .00001 & .00008 & 8.0 & 18 & Stewart (1966) \\
\hline & 519 & & 1.61 & 1.47 & .9 & 30 & Stewart (1966) \\
\hline Suwannee Limestone & $170-180$ & Hillsborough & .54 & .51 & .9 & 21 & This study \\
\hline Ocala Limestone & $300-310$ & Hillsborough & .20 & .37 & 1.8 & 46 & This study \\
\hline \multirow[t]{5}{*}{ Ocala Limestone } & 432 & Hillsborough & 2.8 & .118 & .04 & 44 & $\mathrm{CH}_{2} \mathrm{M}$ Hill, Inc. (1990) \\
\hline & 445 & & .22 & .06 & .3 & 45 & $\mathrm{CH}_{2} \mathrm{M}$ Hill, Inc. (1990) \\
\hline & 500 & & 5.8 & .01 & .002 & 17 & $\mathrm{CH}_{2} \mathrm{M}$ Hill, Inc. (1990) \\
\hline & 505 & & .008 & .01 & 1.25 & 32 & $\mathrm{CH}_{2} \mathrm{M}$ Hill, Inc. (1990) \\
\hline & 550 & & .03 & 8.0 & 266.7 & 21 & $\mathrm{CH}_{2} \mathrm{M}$ Hill, Inc. (1990) \\
\hline \multirow[t]{3}{*}{ Avon Park Formation } & 628 & Pinellas & 1.8 & NR & --- & 48 & Hickey (1977) \\
\hline & 906 & & 1.2 & NR & $\ldots$ & 21 & Hickey (1977) \\
\hline & 710 & & .09 & NR & -.. & 29 & Hickey (1979) \\
\hline
\end{tabular}

The results of the analyses indicate that the sample of the rock core collected from 170 to $180 \mathrm{ft}$ below land surface has a ratio of about $1: 1$ with respect to horizontal to vertical hydraulic conductivity and an effective porosity of 21 percent. The sample of rock collected from 300 to $310 \mathrm{ft}$ below land surface has a ratio of about $2: 1$ and an effective porosity of 46 percent. These values fall within the range of values reported for analyses of rock cores from Pasco, Pinellas, Polk, and Hillsborough Counties (table 4).

\section{Aquifer Tests}

Two Upper Floridan aquifer tests were performed at the study site in 1990. The first test was conducted in July by the USGS and consisted of pumping well 15 with a 20-horsepower submersible electric pump at a rate of $980 \mathrm{gal} / \mathrm{min}$ for 50 hours. The open-hole interval of the pumped well, 67 to $404 \mathrm{ft}$ below land surface, penetrated permeable units one and two of the Upper Floridan aquifer. This test differed from previous tests in that observation wells in the surficial aquifer system, the intermediate confining unit, and all three permeable units of the Upper Floridan aquifer were monitored during the test. Water levels were measured in two Upper Floridan aquifer Regional Observation Monitornng program (ROMP) wells $4 \mathrm{mi}$ northwest of the study site. A rising water-level trend of $0.006 \mathrm{ft} / \mathrm{h}$ was measured in well 15A onsite and in the ROMP wells 4 mi away. The drawdown data for the onsite Upper Floridan aquifer wells were corrected for this trend. A rising water-level trend of $0.01 \mathrm{ft} / \mathrm{h}$ was measured in onsite wells completed in the intermediate confining unit. The drawdown data for intermediate confining unit wells were corrected for this trend. Water levels in wells completed in the surficial aquifer showed no consistent trend, and drawdown data for these wells were not corrected. A rain gage installed by the WCRWSA measured no rainfall during the test. Atmospheric pressure at the site during the test was not monitored, but water-level fluctuations caused by atmospheric pressure changes probably were small compared to water-level fluctuations as a result of pumping during most of the test. 
Table 5. Total drawdown in selected wells at the old Tampa well field during aquifer tests of July and December 1990

[gal/min, gallons per minute; ft, feet; OMW, Ocala monitor well; APMW Avon Park monitor well; APPW, Avon Park Production well]

\begin{tabular}{|c|c|c|c|c|c|}
\hline Test & $\begin{array}{l}\text { Pumped } \\
\text { well (fig. 3) }\end{array}$ & $\begin{array}{l}\text { Discharge } \\
\text { rate } \\
\text { (gal/min) }\end{array}$ & $\begin{array}{l}\text { Observation } \\
\text { well (fig. 3) }\end{array}$ & $\begin{array}{c}\text { Total } \\
\text { observed } \\
\text { drawdown }{ }^{1}(\mathrm{ft})\end{array}$ & $\begin{array}{c}\text { Hydrogeologic } \\
\text { unit penetrated } \\
\text { by observation well }\end{array}$ \\
\hline \multirow[t]{6}{*}{$\begin{array}{l}\text { U.S. Geological Survey, } \\
\text { July } 1990 \text {. Duration, } 50 \text { hours }\end{array}$} & 15 & 980 & $\begin{array}{l}15 \\
17 \\
\text { A }\end{array}$ & $\begin{array}{r}0.4 \\
.0 \\
.0\end{array}$ & Surficial aquifer system \\
\hline & & & $\begin{array}{l}11 \\
16 \\
19 \\
20 \\
22 \\
23\end{array}$ & $\begin{array}{r}3.2 \\
2.4 \\
2.9 \\
1.5 \\
2.0 \\
.5\end{array}$ & Intermediate confining unit \\
\hline & & & $\begin{array}{l}16 \\
21 \\
23\end{array}$ & $\begin{array}{l}3.3 \\
3.9 \\
1.4\end{array}$ & $\begin{array}{l}\text { Permeable unit of Upper } \\
\text { Floridan aquifer: } \\
\text { Unit one }\end{array}$ \\
\hline & & & OMW & 6.2 & Unit two \\
\hline & & & $\begin{array}{l}15 \\
15 \mathrm{a} \\
19 \\
20\end{array}$ & $\begin{array}{r}10.5 \\
6.2 \\
4.3 \\
4.4\end{array}$ & Units one and two \\
\hline & & & APMW & 2.7 & Unit three \\
\hline \multirow[t]{6}{*}{$\begin{array}{l}\text { West Coast Regional Water } \\
\text { Supply Authority }{ }^{2} \text {. Duration, } \\
168 \text { hours }\end{array}$} & APPW & 2,150 & $\begin{array}{l}16 \\
22 \\
23\end{array}$ & $\begin{array}{l}2.7 \\
1.5 \\
.15\end{array}$ & Intermediate confining unit \\
\hline & & & & & $\begin{array}{l}\text { Permeable unit of Upper } \\
\text { Floridan aquifer: }\end{array}$ \\
\hline & & & $\begin{array}{l}16 \\
23\end{array}$ & $\begin{array}{l}3.6 \\
3.0\end{array}$ & Unit one \\
\hline & & & OMW & 6.0 & Unit two \\
\hline & & & 15 & 6.0 & Units one and two \\
\hline & & & $\begin{array}{l}22 \\
\text { APMW } \\
\text { APPW }\end{array}$ & $\begin{array}{l}6.4 \\
6.5 \\
7.7\end{array}$ & Unit three \\
\hline
\end{tabular}

\footnotetext{
${ }^{\mathrm{t}}$ All observed drawdowns corrected for regional trends except data for the surficial aquifer system during the U.S. Geological Survey test of July 1990.

${ }^{2}$ Schreuder and Davis, Inc. (1991).
}

A second aquifer test, conducted in December 1990 by Schreuder and Davis, Inc. (1991), used the Avon Park production well as the pumped well. The well was pumped at a rate of $2,150 \mathrm{gal} / \mathrm{min}$, and drawdown was measured in nine observation wells. The open-hole interval, 550 to $800 \mathrm{ft}$ below land surface, corresponds to permeable unit three of the Upper Floridan aquifer. Total drawdown measured in selected wells at the old Tampa well field at the end of pumping for both aquifer tests is presented in table 5 .
Results of the USGS test indicated that water levels in the shallow wells completed in the surficial aquifer system began to decline between 5 and 24 hours after pumping of well 15 began. The drawdown in the wells ranged from 0.0 to $0.4 \mathrm{ft}$ after 50 hours of pumping. Drawdown of water levels was greatest in the wells closest to the pumped well. Water levels in the intermediate confining unit wells began to decline between 30 and 60 min after pumping of well 15 began at a rate of $980 \mathrm{gal} / \mathrm{min}$. The drawdown in the wells completed 
in the intermediate confining unit ranged from 0.5 to $3.2 \mathrm{ft}$ after 50 hours of pumping. There was no pattern of drawdown in the intermediate confining unit. Some wells farther away from the pumped well had greater drawdowns than wells closer to well 15 , which indicates that leakage to the Upper Floridan aquifer through the intermediate confining unit is variable. The rate of drawdown in wells completed in the Upper Floridan aquifer decreased to less than $0.01 \mathrm{ft} / \mathrm{h}$ after 44 hours of pumping, indicating that the aquifer was approaching steady-state conditions.

Analytical methods used to estimate aquifer hydraulic coefficients assume laminar flow in response to pumping. Because the aquifer at the site has well developed secondary porosity, graphical analyses were made to test the assumption of laminar flow.

Two analyses were made of pumping rate and water-level decline. First, an analysis was made of pumping rate and drawdown data collected prior to the aquifer test of July 1990. The relation between drawdown in wells $15 \mathrm{~A}$ and 19 and the pumping rate from well 15 after 1 hour of pumping is shown in figure 12 .

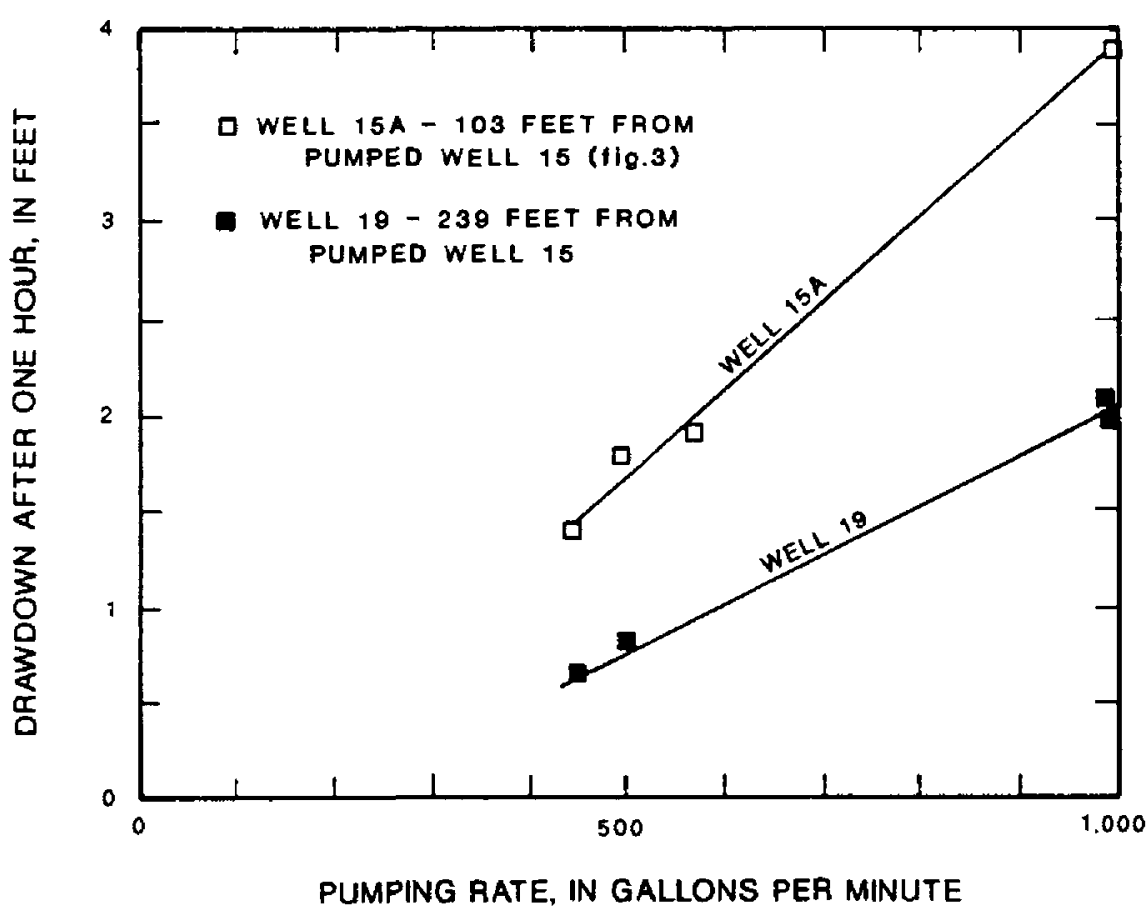

Figure 12. Relation between pumping rate and drawdown in the Upper Floridan aquifer at the old Tampa well field, 1990.

A nearly linear relation exists between drawdown and pumping rate within the limits of measurement error for the pumping rate. A second analysis involved plotting drawdown against distance from the pumped well for all observation wells open to the same depth interval as the pumped well for early-time and late-time data (fig. 13). The plot shows that drawdown decreased with distance from the pumped well, as would be expected for laminar flow conditions. These tests indicate that flow is laminar and that Darcy's equation can be used to estimate hydraulic properties of the aquifer.

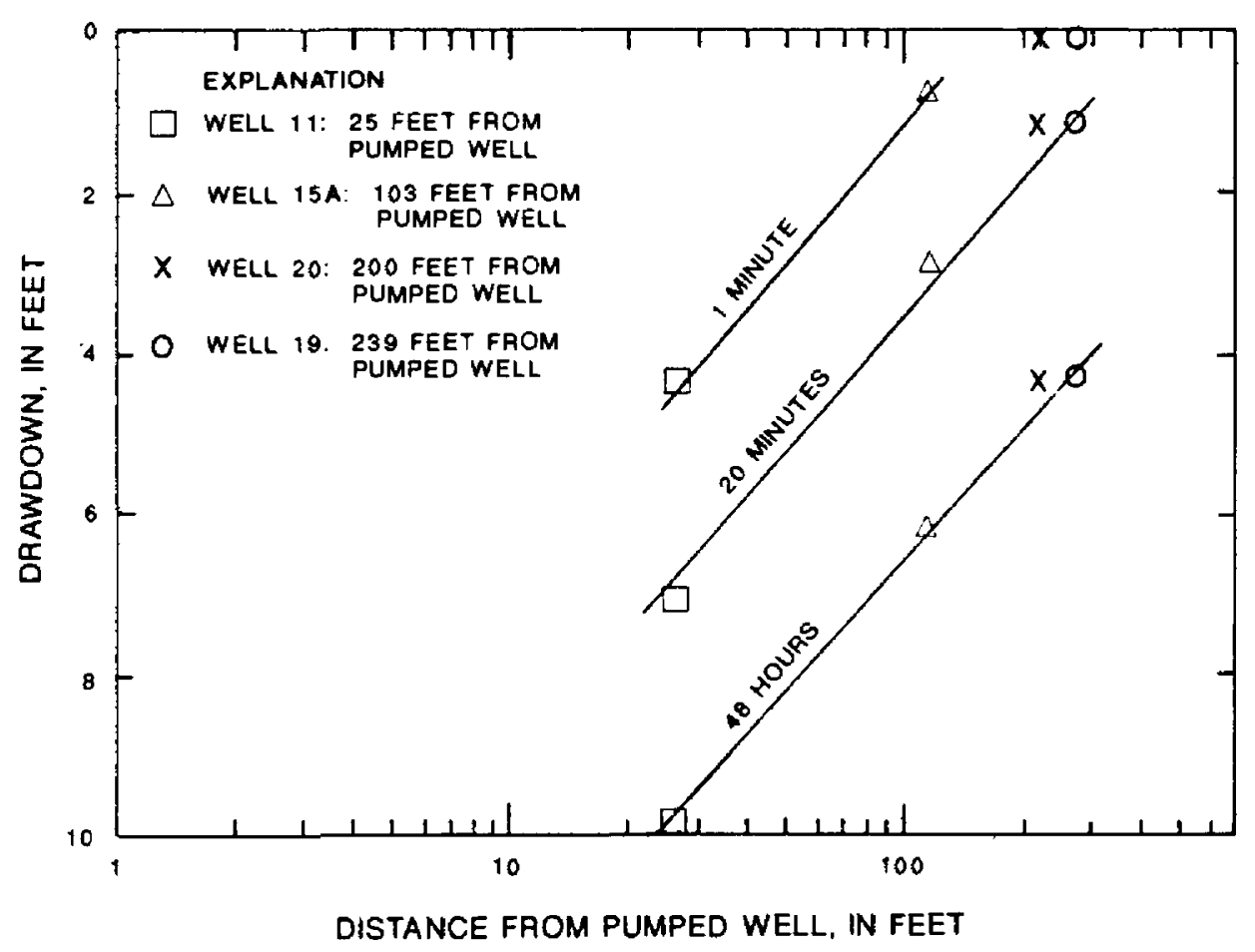

Figure 13. Distance-drawdown plot for Upper Floridan aquifer wells at the old Tampa well field, 1990, after 1 minute, 20 minutes, and 48 hours of pumping well 15 at 980 gallons per minute.

A graphical analysis was performed to test the assumption that the aquifer responds to pumping as an isotropic media. The presence of effective secondary porosity in the form of isolated vertical fractures can create an anisotropic, nonradial flow response in aquifers (Smith and Vaughan, 1985). A semilog plot was made of time-drawdown data for wells 19 and 20, which are nearly equidistant from and form a 90-degree angle with the pumped well (fig. 14). The data points overlie one another indicating that, beyond about a 200 - $\mathrm{ft}$ radius from the pumped well, the aquifer probably had a radial isotropic response to pumping during the 50 -hour aquifer test. If wells 19 and 20 are on rays with the principle axes of transmissivity, they could have similar drawdowns even in an anisotropic system. However, because anisotropy cannot be confirmed, the simpler isotropic model is assumed to be correct. 
A graphical analysis of drawdown data was made to test the assumption of equivalent porous media behavior. A semilog plot of drawdown against time was made for wells 19 and 20 (fig. 14) and for the pumped well (fig. 15). The plots show a straight-line trend for the time interval from 20 to 200 min after pumping began. Early-time and late-time drawdowns do not plot on the straight-line trend. The time-drawdown data from 20 to 200 min after pumping began are most representative of the time interval during which the aquifer responded to pumping as a confined, equivalent porous medium. The early-time drawdown data could indicate the effects of secondary porosity or pump surging. If secondary porosity influences the timedrawdown data, figures 14 and 15 indicate that a large enough volume of aquifer has been stressed after $20 \mathrm{~min}$ of pumping so that the system response resembles that of a homogeneous porous media. The late-time drawdown data indicate the influence of leakage from the overlying and underlying hydrogeologic units.

These analyses support the assumption that the upper $400 \mathrm{ft}$ of the Upper Floridan aquifer at the old Tampa well field responds to pumping as a semiconfined, horizontally isotropic, equivalent porous medium after approximately 20 min of pumping. Flow seems to be laminar for the range of discharge rates tested. The hydraulic effects of effective secondary porosity, if any, are indistinguishable from the total aquifer response after about $20 \mathrm{~min}$ of pumping at a rate of approximately $1,000 \mathrm{gal} / \mathrm{min}$.

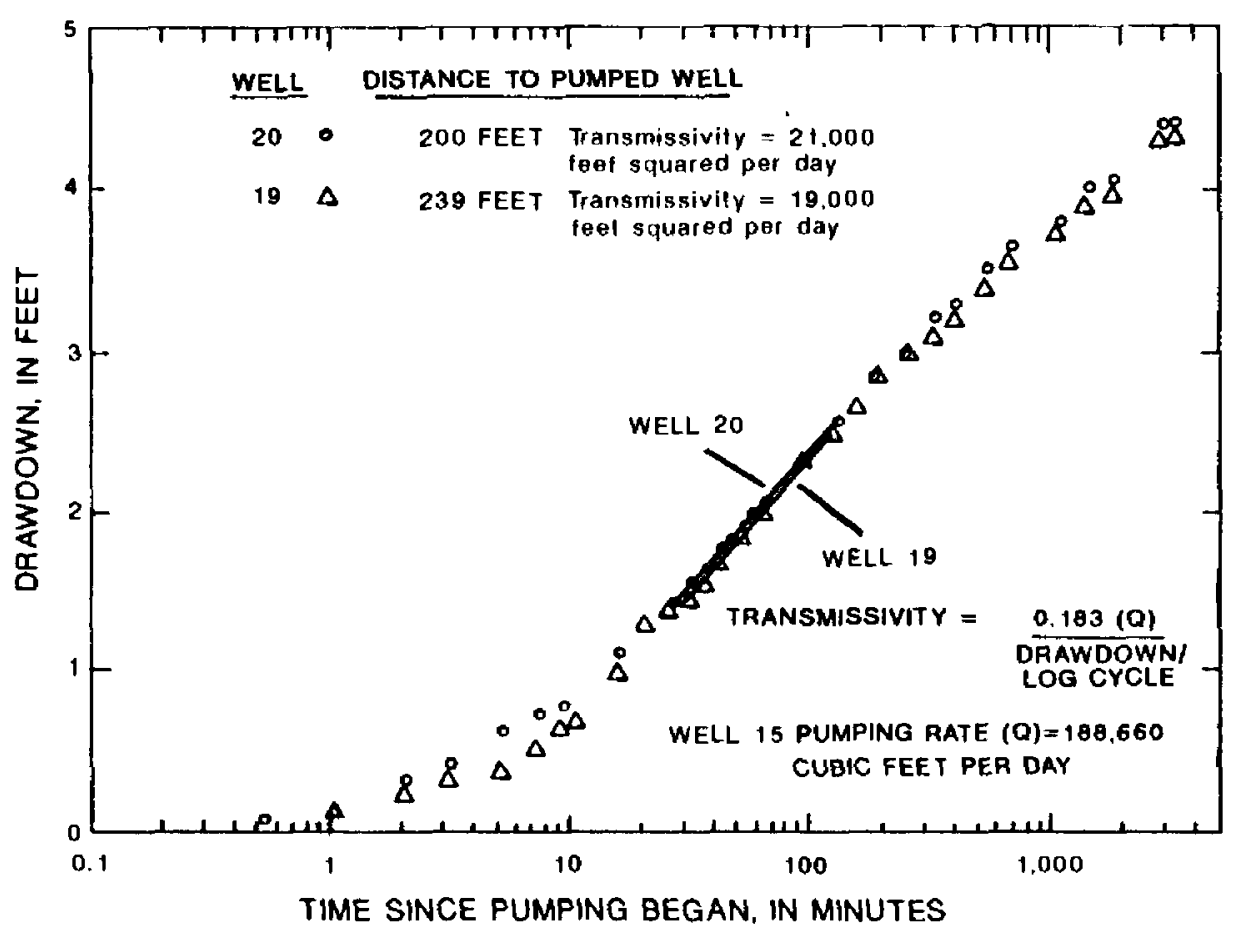

Figure 14. Time-drawdown data for Upper Floridan aquifer wells 19 and 20 at the old Tampa well field, 1990.

Transmissivity of the pumped interval was estimated from the plot of time-drawdown data and for wells 19 and 20 (fig. 14) and for the pumped well (fig. 15). The timedrawdown data before $20 \mathrm{~min}$ and after $200 \mathrm{~min}$ after pumping began were not used. The open-hole interval of the pumped well fully penetrates the two upper permeable zones of the Upper Floridan aquifer and is separated from

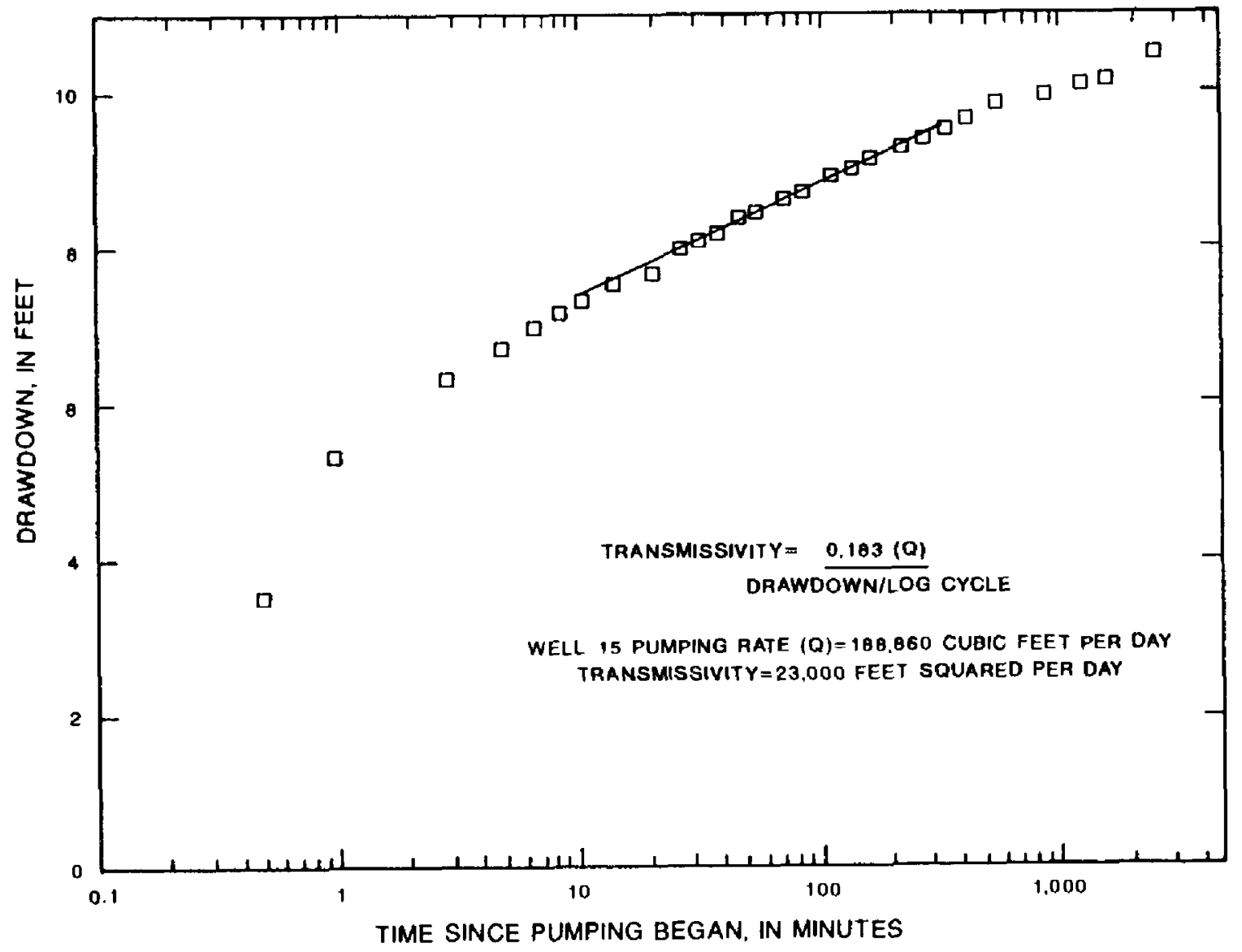

Figure 15. Time-drawdown plot for well 15 at the old Tampa well field, 1990. 
the lower permeable zone by a semiconfining unit. Pumping flowmeter logs indicate that the semiconfining unit does not transmit measurable quantities of water to wells. Therefore, the pumped well was assumed to fully penetrate the tested zones and no correction for partial penetration was necessary. A straight-line solution (Lohman, 1979, p. 23) yielded estimated transmissivities of the tested interval in the pumped well, well 19, and well 20 of $23,000,19,000$, and $21,000 \mathrm{ft}^{2} / \mathrm{d}$, respectively. The transmissivity estimate is representative of the cumulative transmissivity of the individual units penetrated.

\section{CONCEPTUAL HYDROGEOLOGIC MODEL}

A conceptual hydrogeologic model of the groundwater flow system at the old Tampa well field was formulated using the results of onsite drilling, the geologic section (fig. 7), the distribution of permeability in the Upper Floridan aquifer as determined using flowmeter and fluid resistivity logs (figs. 8 and 9), and the results of aquifer tests. A water budget was calculated for the study area using the configurations of the water table in the surficial aquifer system and the potentiometric surface in the Upper Floridan aquifer and the estimated hydraulic coefficients of these hydrogeologic units.

In the conceptual hydrogeologic model of the old Tampa well field, the surficial aquifer system and the intermediate confining unit rest unconformably on the variable paleokarst surface of the Upper Floridan aquifer (fig. 16). The Upper Floridan aquifer is layered; at least three permeable zones occur from 50 to 250,380 to 425 , and 550 to $800 \mathrm{ft}$ below land surface and are separated by two semiconfining units occurring from 250 to 380 and 425 to $550 \mathrm{ft}$ below land surface.

Results of analyses of aquifer test data indicate that the Upper Floridan aquifer at the test site responds to pumping as a horizontally isotropic, equivalent porous medium. The total thickness of the Upper Floridan aquifer at the site is estimated to be $1,100 \mathrm{ft}$ (Miller, 1986). The middle confining unit of the Floridan aquifer system, about 1,100 to $1,200 \mathrm{ft}$ below land surface (Ryder and others, 1980; Miller, 1986), underlies the Upper Floridan aquifer in this conceptual model. The Lower Floridan aquifer was not modeled at the study site.

The surficial aquifer system was estimated to have a horizontal hydraulic conductivity of about $10 \mathrm{ft} / \mathrm{d}$. The sands of the surficial aquifer system grade down- ward to marl and clay of the intermediate confining unit. The intermediate confining unit was estimated to have a vertical hydraulic conductivity of about $0.01 \mathrm{ft} / \mathrm{d}$. For the measured thickness of the intermediate confining unit at the site, this value yields leakance coefficient values ranging from 0.001 to $0.0002(\mathrm{ft} / \mathrm{d}) / \mathrm{ft}$, which is within the range of reported leakance coefficient values for this unit (Wolansky and Corral, 1985).

The Upper Floridan aquifer, based on the results of aquifer tests, was estimated to have a transmissivity on the order of $60,000 \mathrm{ft}^{2} / \mathrm{d}$. The transmissivity value calculated for well 15 was divided proportionally between permeable units one and two of the Upper Floridan aquifer, and the semiconfining unit that separates them, using pumping flowmeter surveys of well 15. The estimated transmissivities are $10,350 \mathrm{ft}^{2} / \mathrm{d}$ for permeable unit one, $1,150 \mathrm{ft}^{2} / \mathrm{d}$ for the intervening semiconfining unit, and $11,500 \mathrm{ft}^{2} / \mathrm{d}$ for permeable unit two. The transmissivity of that part of permeable unit three from 550 to $800 \mathrm{ft}$ below land surface was calculated to be approximately $30,000 \mathrm{ft}^{2} / \mathrm{d}$ (Schreuder and Davis, Inc., 1991). The total transmissivity of the lower part of the Upper Floridan aquifer (550-1,150 ft below land surface) was estimated to be on the order of $40,000 \mathrm{ft}^{2} / \mathrm{d}$.

Water levels in wells completed in the surficial aquifer system and in wells completed in different permeable units of the Upper Floridan aquifer were measured to determine the vertical ground-water head gradient at the study site in June 1990. The water level in the surficial aquifer was about $5 \mathrm{ft}$ higher than the water level in the Upper Floridan aquifer. There was no measurable difference between the head in permeable units one and two of the Upper Floridan aquifer, but the head in permeable unit three was about $0.5 \mathrm{ft}$ less than in the overlying units of the Upper Floridan aquifer. Water levels in wells completed in the surficial aquifer system and the intermediate confining unit declined in response to pumping the Upper Floridan aquifer. This decline indicates hydraulic connection between the surficial aquifer system and the Upper Floridan aquifer; therefore, the Upper Floridan aquifer is best described as semiconfined.

Ground-water withdrawals in northeastern Hillsborough County vary seasonally. Average annual permitted withdrawal for agricultural use in the vicinity of the study site is $26 \mathrm{Mgal} / \mathrm{d}$, with a maximum daily permitted withdrawal for agricultural use of 286 $\mathrm{Mgal} / \mathrm{d}$ (Bengtsson and others, 1986). In 1983 and 1985 , the water level in well 15 declined about $18 \mathrm{ft}$ 


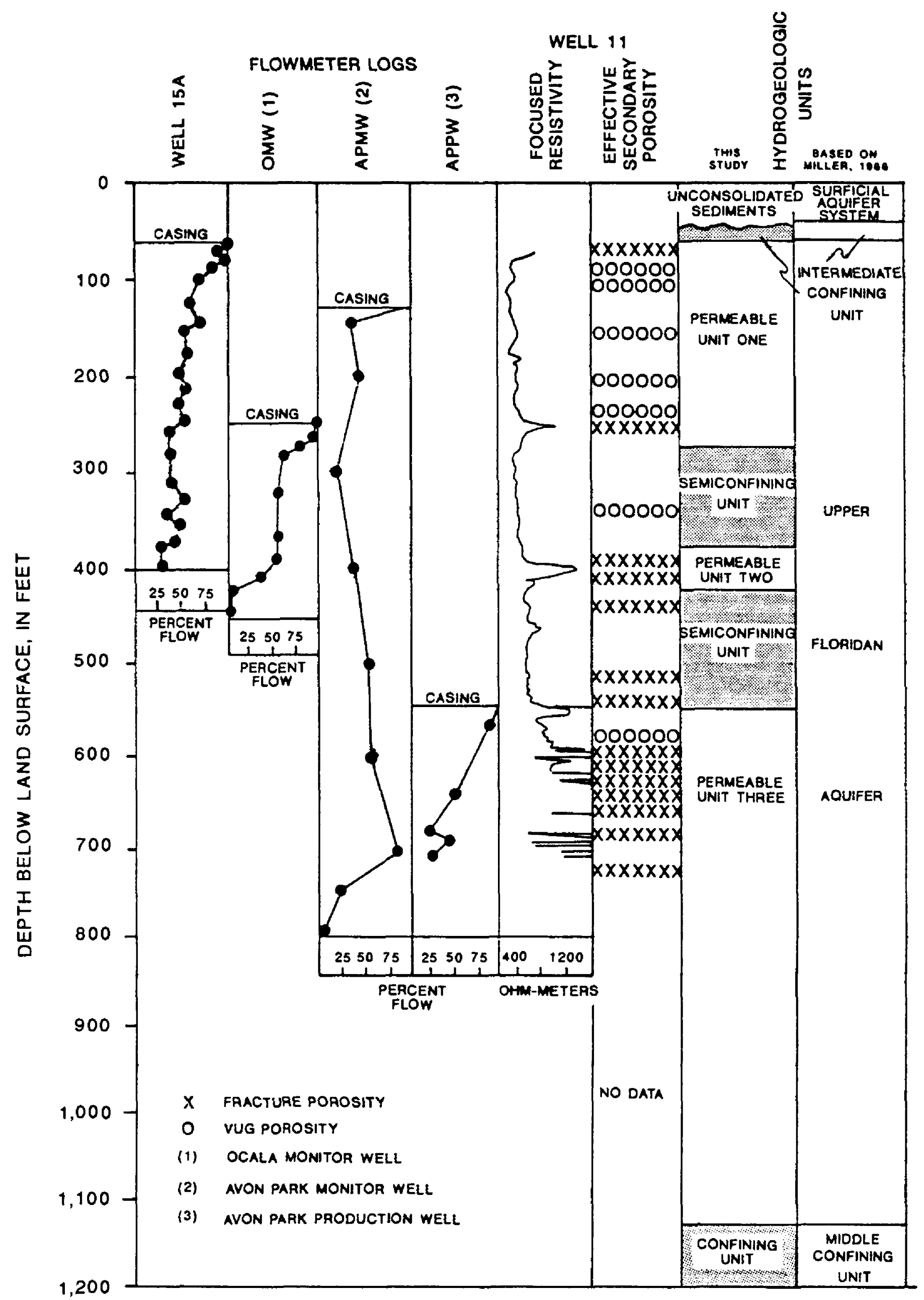

Figure 16. Hydrogeologic framework at the old Tampa well field. 
during 2 days as a result of heavy pumping to protect crops from frost damage. Similar events occurred in 1977 and 1981, but the water-level declines were not as great. Rapid water-level declines can result in the formation of sinkholes and can interrupt the water supply to residents with shallow wells (Bengtsson and others, 1986). A water budget for the study site was estimated for July 1990 , assuming steady-state conditions during the season of low pumpage. The distribution of the water table in the surficial aquifer system and the potentiometric surface in the Upper Floridan aquifer in July 1990 and the hydraulic coefficients estimated from aquifer tests were used to calculate the volume of water entering the Upper Floridan aquifer from the surficial aquifer system and the volume of water entering the study site by regional flow through the Upper Floridan aquifer. Vertical leakage from the surficial aquifer system amounted to approximately $62,000 \mathrm{ft}^{3} / \mathrm{d}$. Regional flow in the Upper Floridan aquifer through the site was estimated to be about $690,000 \mathrm{ft}^{3} / \mathrm{d}$.

The complexity of the ground-water flow system makes it difficult to use analytical methods to determine the hydraulic coefficients of the Upper Floridan aquifer. A numerical model of the ground-water flow system at the study site was constructed and calibrated using the results of the two aquifer tests performed in 1990. The hydraulic coefficients estimated with analytical methods were compared to those necessary to calibrate the numerical model. This comparison provided a way to determine if the estimated hydraulic coefficients were reasonable approximations for the Upper Floridan aquifer at the site.

\section{NUMERICAL MODEL}

A finite-difference numerical model was used to simulate the ground-water flow system at the old Tampa well field. The objectives of the modeling were to: (1) provide additional estimates of the hydraulic coefficients of the Upper Floridan aquifer; (2) test the conceptual model of the ground-water flow system; and (3) generate the velocity-vector field required by the particle-tracking program to simulate the groundwater travel times measured with tracer tests. The USGS modular model "MODFLOW" (McDonald and Harbaugh, 1988) was selected because of its ability to simulate layered aquifers and because the particletracking program "MODPATH" (Pollock, 1989) uses the output from the modular model. The MODFLOW model can use the quasi-three-dimensional approach to simulate flow between multiaquifer systems (twodimensional $(\mathrm{x}, \mathrm{y})$ horizontal flow through aquifers and vertical ( $\mathrm{z}$ ) flow through confining units using leakance terms and ignoring storage) or the three-dimensional approach by specifying a model layer for each hydrogeologic unit. Steady-state and transient simulations were made.

\section{Model Grid and Boundary Conditions}

The conceptual model of the ground-water flow system at the old Tampa well field was represented using a 6-layer numerical model with a 28 -column by 28-row variable grid simulating a 6,112 by 6,112 by 1,200-ft volume of aquifer system (fig. 17). Model layer 1 represents the surficial aquifer system. The intermediate confining unit is simulated with a vertical leakance term using the quasi-three-dimensional approach. The remaining hydrogeologic units are modeled with the three-dimensional approach by assigning individual model layers to each hydrogeologic unit. Model layers 2, 4, and 6 represent permeable units one, two, and three of the Upper Floridan aquifer, respectively. Model layers 3 and 5 represent the semiconfining units of the Upper Floridan aquifer. The model grid locations of the 12 wells completed in the Upper Floridan aquifer that were used as control points for model calibration are shown in figure 18.

The heads in the surficial aquifer system, after drawdown due to pumping had stabilized, were used as a specified head boundary in model layer 1 for the steady-state simulation. For the transient simulations, the heads in the surficial aquifer system before pumping began were used as initial conditions in model layer 1 , and the layer was activated so that drawdown could occur. The model layers representing the Upper Floridan aquifer were bounded by general head boundaries on all sides. A conductance term was calculated for each general head grid cell based on a specified head at a distance of 1"mi from the model boundary, or about $2.2 \mathrm{mi}$ from the pumped well, and the transmissivity value determined for the hydrologic unit represented by that model layer using the results of onsite aquifer withdrawal tests. Based on the assumption of horizontally isotropic conditions, one transmissivity value was used to calculate the conductance terms for the general head boundary cells for each layer. The distance between the general-head boundary and the model boundary was set at $1 \mathrm{mi}$ for two reasons: (1) the distance to zero drawdown was about $1 \mathrm{mi}$ based on the 


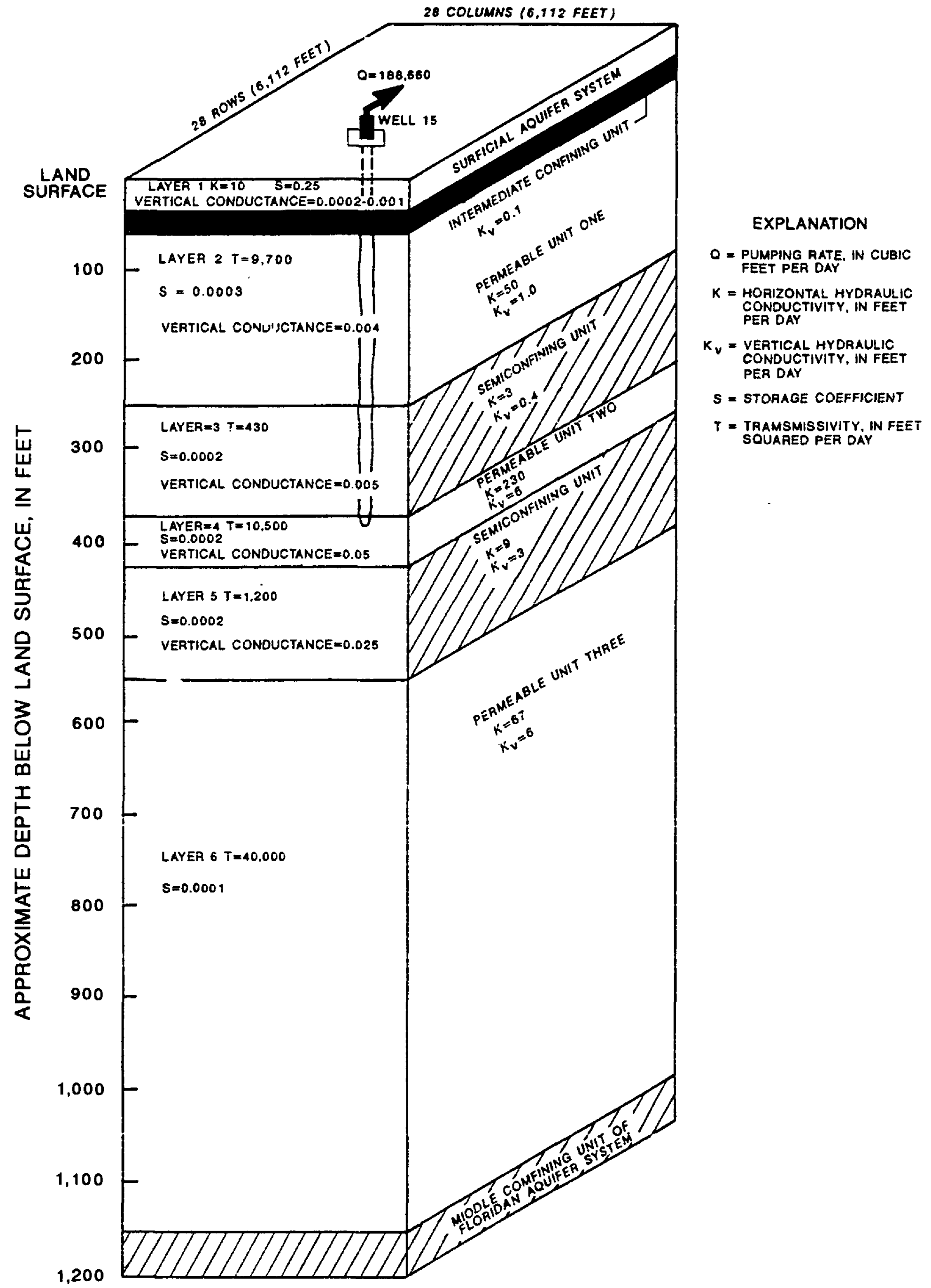

Figure 17. Hydrogeologic framework of the numerical model of the ground-water flow system at the old Tampa well field. 
relatively small withdrawal rate of the pumped well and the estimated permeability and storage properties of the Upper Floridan aquifer; and (2) the projection of the estimated hydraulic coefficients at the test site beyond the vicinity of the old Tampa well field cannot be justified without additional detailed hydrogeologic data. The lower boundary of the model was a no-flow boundary, simulating the middle confining unit of the Floridan aquifer system.

Initial water-level conditions for model simulations were established using onsite and regional waterlevel measurements. Estimated water-level altitudes were used as the starting head values in model nodes that do not contain wells. The configuration of the potentiometric surface within the study area remained unchanged between May 1988 (Lewelling, 1989), September 1988 (Barr, 1989), and September 1989 (Knochenmus and Barr, 1990), but did fluctuate about $10 \mathrm{ft}$. Based on the history of water-level fluctuations within the study area, the potentiometric surface for July 1990 was estimated by subtracting $4 \mathrm{ft}$ of altitude from the potentiometric-surface altitudes of September 1989 (Knochenmus and Barr, 1990). Water levels in wells at the old Tampa well field were used as starting

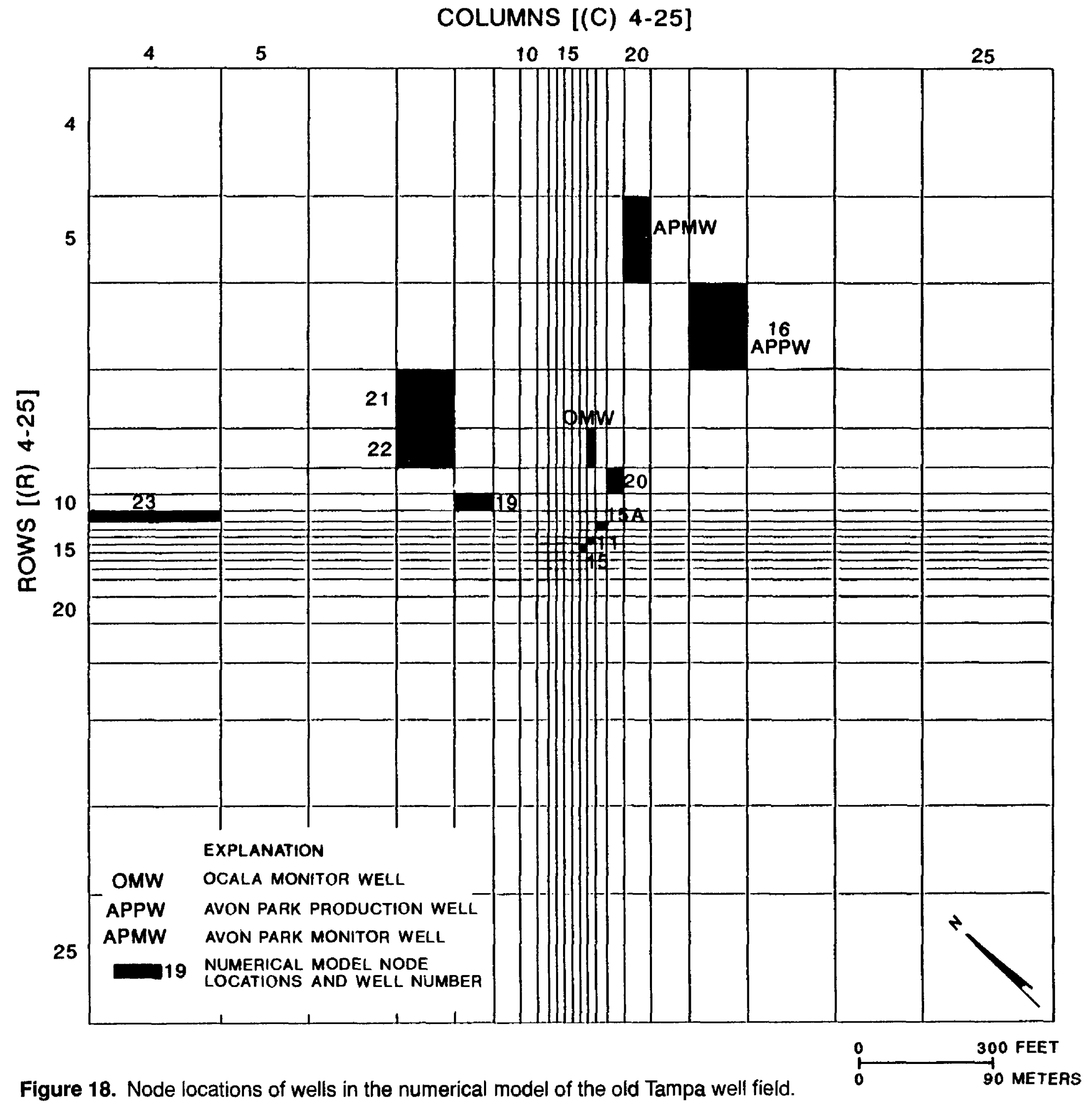




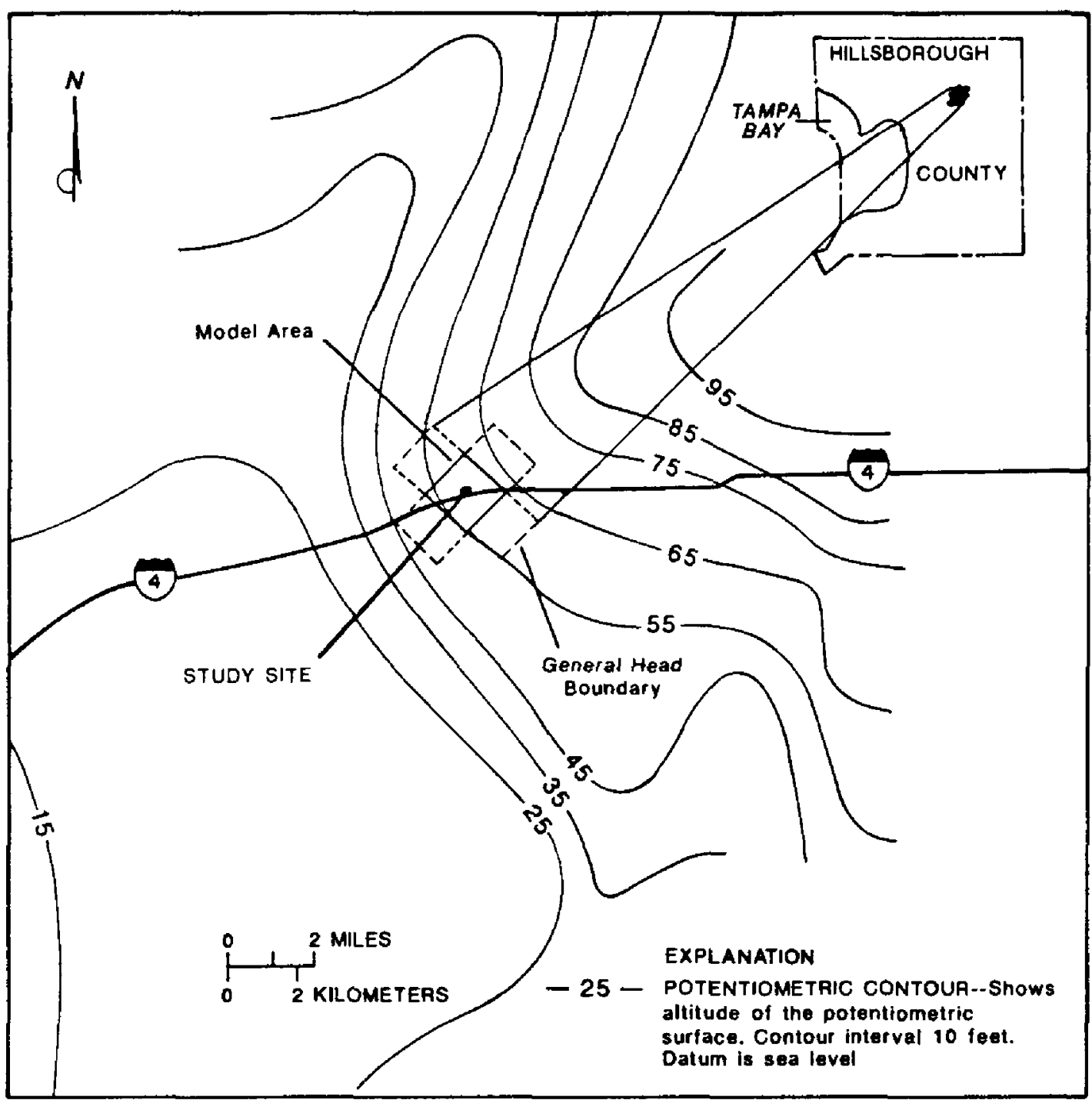

Figure 19. Orientation of the numerical model grid to the local potentiometric surface of the Upper Floridan aquifer, July 1990.

heads for the model nodes in which the wells were located. The model grid was oriented to the northeastsouthwest so that the model boundaries were approximately parallel or orthogonal to the regional potentiometric-surface contours of the Upper Floridan aquifer (fig. 19).

\section{Input Parameters}

Input parameters for the numerical model were derived from field tests and from the model calibration process (table 6). The transmissivities of model layers were based on results of aquifer tests, core analyses, and pumping flowmeter logs. Transmissivities estimated from aquifer tests conducted in 1961, 1985, and 1990 were used as starting values for the model hydraulic parameters and adjusted (table 6) until the simulated drawdowns approximated the observed drawdowns at the end of the aquifer test (table 7). The storage coefficients used for model layers were estimated using ranges of values for similar sediments and from the compressibility of limestone (Freeze and Cherry, 1979).
There are several disparities between the hydraulic coefficients determined for rock cores (table 4) and hydraulic coefficients listed in table 6 . These disparities are due to the difference between the part of the aquifer represented by rock cores and the part of the aquifer represented by a model layer. The rock-core analyses (table 4) are representative of small vertical intervals of the aquifer matrix. Results of the analyses indicate a ratio of about $1: 1$ between horizontal to vertical hydraulic conductivity for the aquifer matrix and a maximum horizontal hydraulic conductivity of $8 \mathrm{ft} / \mathrm{d}$. Hydraulic coefficients used in the numerical model, however, represent entire hydrologic units that include both relatively permeable and impermeable layers of the aquifer matrix and permeability resulting from effective secondary porosity. As a result, the equivalent horizontal hydraulic conductivities for the transmissivity values used in the model and the ratios of horizontal to vertical hydraulic conductivity used to estimate the vertical-conductance values in the model are significantly higher than the values reported for individual rock-cores in table 4. 
Table 6. Input parameters for model of the Old Tampa well field [ft/d, feet per day]

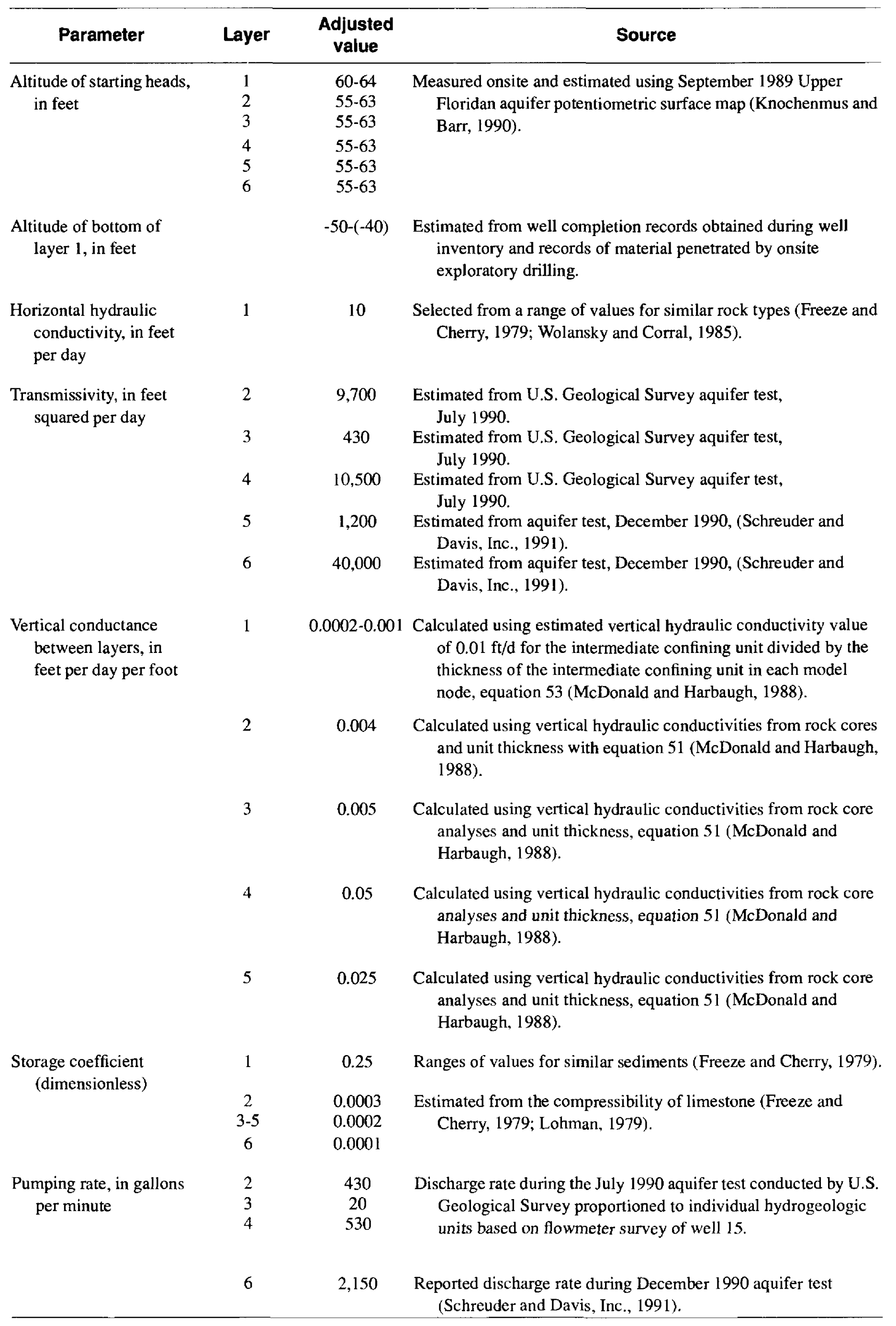


Table 7. Measured and model-simulated drawdowns in the Upper Floridan aquifer at the old Tampa well field for steadystate calibration of two aquifer tests

[gal/min, gallons per minute; ft, feet; APMW, Avon Park monitor well; OMW, Ocala monitor well. Residuals were computed by subtracting the model-simulate drawdown from the measured drawdown. A positive value indicates that the model-simulated drawdown is less than the measured drawdown, and the reverse is indicated by a negative residual]

\begin{tabular}{|c|c|c|c|c|c|c|c|c|c|c|}
\hline \multirow[b]{2}{*}{ Test } & \multirow{2}{*}{$\begin{array}{l}\text { Pumped } \\
\text { well } \\
\text { (fig. 3) }\end{array}$} & \multirow{2}{*}{$\begin{array}{l}\text { Dis- } \\
\text { charge } \\
\text { rate } \\
\text { (gal/min) }\end{array}$} & \multirow[b]{2}{*}{$\begin{array}{l}\text { Well } \\
\text { (fig. 3) }\end{array}$} & \multirow{2}{*}{$\begin{array}{l}\text { Measured } \\
\text { drawdown } \\
\text { in well (ft) }\end{array}$} & \multicolumn{2}{|c|}{$\begin{array}{c}\text { Uniform } \\
\text { transmissivity model }\end{array}$} & \multicolumn{2}{|c|}{$\begin{array}{l}\text { Transmissivity } \times 10 \\
\text { simulating fractures }\end{array}$} & \multicolumn{2}{|c|}{$\begin{array}{l}\text { Transmissivity } \times 0.1 \\
\text { simulating fractures }\end{array}$} \\
\hline & & & & & $\begin{array}{l}\text { Simulated } \\
\text { drawdown } \\
\text { at node }(\mathrm{ft})\end{array}$ & $\begin{array}{l}\text { Residual } \\
\text { (ft) }\end{array}$ & $\begin{array}{l}\text { Simulated } \\
\text { drawdown } \\
\text { at node }(\mathrm{ft})\end{array}$ & $\begin{array}{l}\text { Residual } \\
\text { (ft) }\end{array}$ & $\begin{array}{l}\text { Simulated } \\
\text { drawdown } \\
\text { at node (ft) }\end{array}$ & $\begin{array}{c}\text { Residual } \\
\text { (ft) }\end{array}$ \\
\hline $\begin{array}{l}\text { U.S. Geological } \\
\text { Survey calibration } \\
\text { (50 hours) }\end{array}$ & 15 & 980 & $\begin{array}{c}15 \mathrm{~A} \\
16 \\
19 \\
20 \\
21 \\
23 \\
\text { APMW }\end{array}$ & $\begin{array}{l}6.2 \\
3.3 \\
4.3 \\
4.4 \\
3.9 \\
1.4 \\
2.7\end{array}$ & $\begin{array}{l}5.5 \\
3.3 \\
3.8 \\
4.3 \\
3.6 \\
2.8 \\
1.9\end{array}$ & $\begin{array}{r}0.7 \\
.0 \\
.5 \\
.1 \\
.3 \\
-1.4 \\
.8\end{array}$ & $\begin{array}{l}5.2 \\
3.0 \\
3.3 \\
4.0 \\
2.8 \\
2.5 \\
1.8\end{array}$ & $\begin{array}{r}1.0 \\
.3 \\
1.0 \\
.4 \\
1.1 \\
-1.1 \\
.9\end{array}$ & $\begin{array}{l}6.1 \\
3.9 \\
4.5 \\
4.8 \\
4.8 \\
3.3 \\
2.1\end{array}$ & $\begin{array}{r}0.1 \\
-.6 \\
-.2 \\
-.4 \\
-.9 \\
-1.9 \\
.6\end{array}$ \\
\hline $\begin{array}{l}\text { Schreuder and } \\
\text { Davis, Inc. (1991) } \\
\text { (168 hours) }\end{array}$ & APPW & 2,150 & $\begin{array}{c}15 \\
16 \\
22 \\
\text { OMW } \\
\text { APMW }\end{array}$ & $\begin{array}{l}6.0 \\
3.6 \\
6.4 \\
6.0 \\
6.5\end{array}$ & $\begin{array}{l}5.0 \\
3.1 \\
5.9 \\
5.2 \\
7.3\end{array}$ & $\begin{array}{r}1.0 \\
.6 \\
.5 \\
.8 \\
-.8\end{array}$ & $\begin{array}{l}4.7 \\
3.1 \\
5.1 \\
4.8 \\
6.8\end{array}$ & $\begin{array}{r}1.3 \\
.5 \\
1.3 \\
1.2 \\
-.3\end{array}$ & $\begin{array}{l}5.7 \\
3.3 \\
7.0 \\
5.9 \\
8.3\end{array}$ & $\begin{array}{r}.3 \\
.3 \\
-.6 \\
.1 \\
-1.8\end{array}$ \\
\hline
\end{tabular}

Additional disparity exists between the transmissivities estimated using analytical methods and those necessary to calibrate the numerical model. The transmissivity of the semiconfining unit separating permeable units one and two (model layer 3 ) was estimated to be about $1,150 \mathrm{ft}^{2} / \mathrm{d}$ using the results of aquifer tests and flow-meter surveys, but a transmissivity of 430 $\mathrm{ft}^{2} / \mathrm{d}$ was necessary to calibrate the model. The difference between the two is within the measurement error of the methods used to calculate the value and illustrates the difficulty in determining accurate numbers for hydraulic coefficients of complex ground-water flow systems.

The intermediate confining unit was simulated using the quasi-three-dimensional approach. This approach assumes that the confining unit makes no contribution to the storage capacity of the aquifer (McDonald and Harbaugh, 1988). Values of vertical conductance used for layer 1 were calculated using equation 53 of McDonald and Harbaugh (1988), which is the equation for the leakage coefficient. For layer 1 , vertical conductance ranged from 0.0002 to $0.001(\mathrm{ft} / \mathrm{d}) / \mathrm{ft}$, and values were assigned to model nodes using the estimated thickness of the intermediate confining unit in that model node (fig. 11) and a uniform vertical hydraulic conductivity of $0.01 \mathrm{ft} / \mathrm{d}$.

\section{Steady-State Calibration}

The results of the 50-hour aquifer test indicated that the Upper Floridan aquifer approached steadystate conditions within 44 hours after pumping began at a rate of $980 \mathrm{gal} / \mathrm{min}$. A steady-state calibration to the 50-hour aquifer test was achieved when the drawdown in model layers 2, 4, and 6 approximated the drawdown measured in seven wells completed in permeable units one, two, and three of the Upper Floridan aquifer within an error criteria of plus or minus $1 \mathrm{ft}$. The simulated drawdown in model layer 2 was calibrated to observed drawdown in wells completed in permeable unit one of the Upper Floridan aquifer, and the simulated drawdown in model layer 4 was calibrated to observed drawdown in wells open to both permeable units one and two of the Upper FLoridan aquifer. The simulated drawdown in model layer 6 was calibrated to observed drawdown in the Avon Park monitor well, completed in permeable unit three of the Upper Floridan aquifer.

The calibration of the steady-state simulation was evaluated by computing the residual difference between the observed water-level drawdowns in seven observation wells and the simulated drawdowns at the corresponding model nodes (table 7). Simulated drawdowns matched the observed drawdowns within a range of $0.8 \mathrm{ft}$ below to $1.4 \mathrm{ft}$ above the observed 
drawdown; however, excluding well 23, the simulated drawdowns matched the observed drawdowns within the error criteria of plus or minus $1 \mathrm{ft}$. The water budget for this simulation indicated that 42 percent of the pumpage $\left(79,000 \mathrm{ft}^{3} / \mathrm{d}\right)$ was derived as leakage from model layer 1 and 58 percent $\left(110,000 \mathrm{ft}^{3} / \mathrm{d}\right)$ was from the general head boundaries.

The steady-state calibration was tested by simulating the 168-hour aquifer test conducted at the site in December 1990 and comparing measured drawdowns in five observation wells completed in the Upper Floridan aquifer with simulated drawdowns in the corresponding model nodes. The general head boundary conductance terms were reused, but the starting heads in the model layers and the general head boundary nodes were modified to reflect site conditions at the time of the test. The model simulated the measured drawdowns in five Upper Floridan aquifer observation wells within a range of $1.0 \mathrm{ft}$ below to $0.8 \mathrm{ft}$ above the observed drawdowns (table 7). The water budget for this simulation indicates that 20 percent of the pumpage $\left(84,000 \mathrm{ft}^{3} / \mathrm{d}\right)$ was derived from leakage from model layer 1 and 80 percent $\left(330,000 \mathrm{ft}^{3} / \mathrm{d}\right)$ was from the general head boundaries. Additional simulations of the aquifer tests were made to evaluate the possibility that photolineaments at the site represent a fracture zone. Photolineaments A and B were simulated as a fracture zone of increased permeability resulting from secondary permeability and as a fracture zone of decreased permeability resulting from recrystallization of the limestone or infilling on the fractures with clay and sand or both. Photolineaments C and D were not evaluated because data were not available to determine the hydrogeologic significance of C and D.

Transmissivity values for all model layers were increased one order of magnitude and then decreased one order of magnitude for model nodes representing the area through which photolineaments $\mathrm{A}$ and $\mathrm{B}$ were traced (fig. 4). The vertical conductance between model layers was not increased or decreased. Borehole videos of wells at the site indicated very few high angle fractures longer than 2 to $5 \mathrm{ft}$; therefore, the probability of a semiconfining layer being breached by fractures and effective secondary porosity is low. Additionally, aquifer test data indicated that the semiconfining units retarded the flow of water between more permeable units.

Changes in the transmissivity of the model nodes simulating photolineaments $\mathrm{A}$ and $\mathrm{B}$ had measurable but relatively little effect on simulated drawdowns, possibly because they are oriented approximately parallel to the direction of flow through the model. Results of simulating possible fracture zones are shown in figure 20 and listed in table 7.

Simulated drawdowns in the model nodes corresponding to observation wells decreased when photolineaments A and B were modeled as a fracture zone of increased transmissivity (table 7). Simulated drawdowns in the model nodes corresponding to observation wells generally were increased when photolineaments A and B were modeled as a fracture zone of decreased transmissivity (table 7). Comparison of the simulated drawdowns for the uniform transmissivity model to the fracture transmissivity models indicates that the calibration of the model to the observed data was either not improved or slightly worse using increased and decreased transmissivities. The results of model simulations neither confirmed nor precluded the existence of fractures at the test site, and the uniform transmissivity model was accepted as a representative model of the ground-water flow system at the old Tampa well field.

\section{Transient Calibration}

A transient simulation of the 50-hour aquifer test was made to obtain an additional estimate of the storage coefficient of the Upper Floridan aquifer. Calibration of the transient model was achieved by adjusting the storage coefficients of the layers simulating the Upper Floridan aquifer. The vertical-conductance values and transmissivities used in the calibrated steadystate model were not changed. Initially, the storage coefficients from onsite aquifer tests (table 3 ) were used; however, the storage coefficient estimated using the compressibility of limestone $\left(10^{-4}\right)$ produced a better calibration. A specific yield of 0.25 , representative of unconfined sand, was assigned to the surficial aquifer system.

The first 6 hours of pumping were simulated with two 3-hour time steps, and the next 6 hours were simulated with a single time step. The remaining aquifer test was simulated with two 12-hour and one 14-hour time steps. The total simulated time of pumping was 50 hours. The simulated stressed interval of the Upper Floridan aquifer was the depth interval from about 50 to $425 \mathrm{ft}$ below land surface. Observed and modelsimulated hydrographs for seven wells completed in the Upper Floridan aquifer are shown in figure 21. The water budget at the end of the last time step indicated 


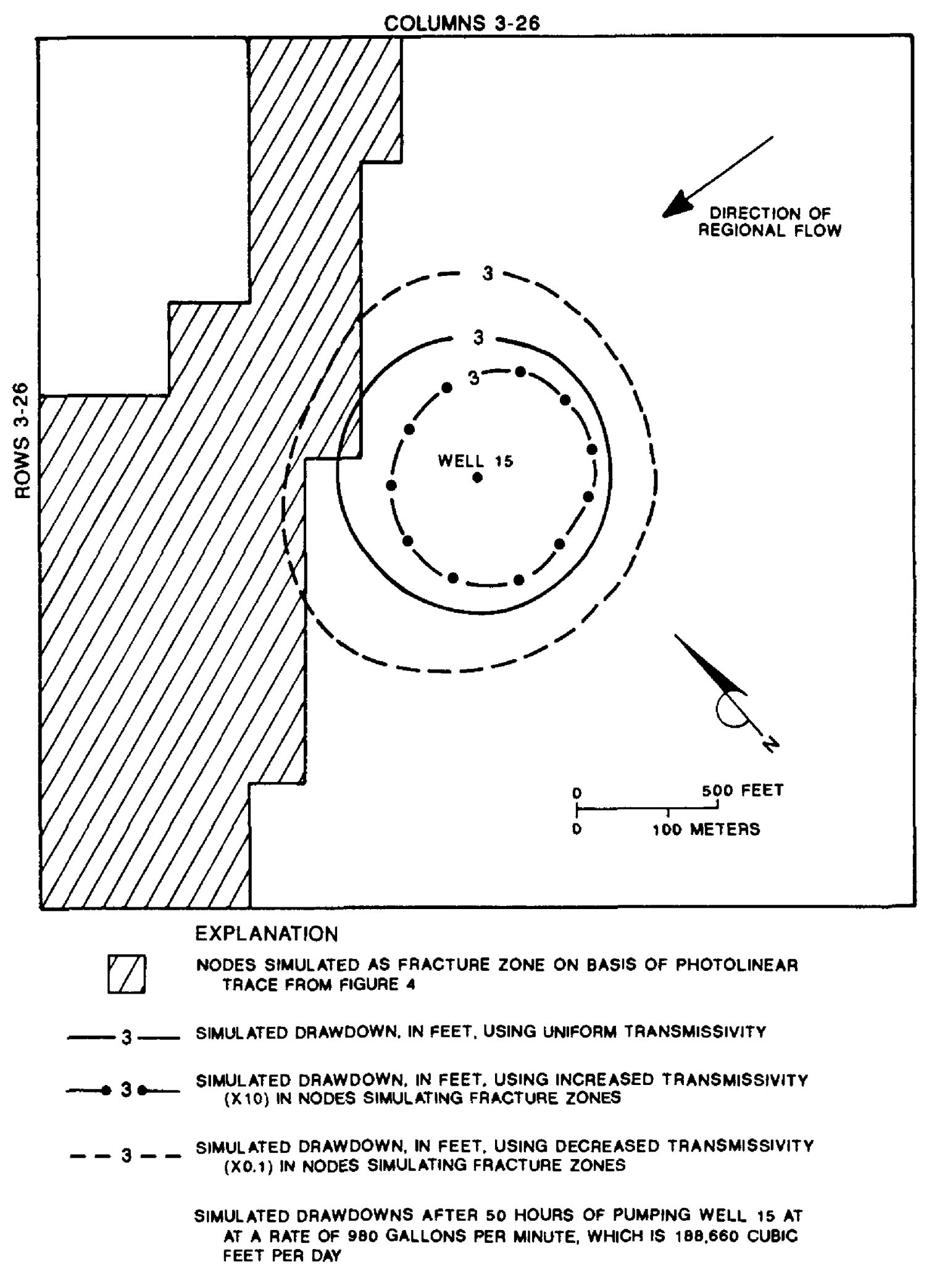

Figure 20. Simulated drawdowns in permeable unit two of the Upper Floridan aquifer for the uniform transmissivity model and for models using increased and decreased transmissivity in nodes simulating a fracture zone.

that about 42 percent of the pumpage $\left(79,000 \mathrm{ft}^{3} / \mathrm{d}\right)$ was derived from leakage from the surficial aquifer system, about 56 percent $\left(106,000 \mathrm{ft}^{3} / \mathrm{d}\right)$ was from boundary flow, and less than 2 percent $\left(4,000 \mathrm{ft}^{3} / \mathrm{d}\right)$ was derived from storage.

A transient simulation also was conducted of a 168-hour aquifer test in which the Avon Park production well was pumped. The first 3 hours of pumping were simulated with a single time step, the next 9 hours with a single time step, and the next 48 hours with two 24-hour time steps. The remaining aquifer test was simulated with two 40 -hour and a single 28 -hour time step. The simulated stressed interval of the Upper Floridan aquifer was the depth interval from 550 to 1,150 feet below land surface. The water budget at the end of the last time step indicated that about 20 percent of the water withdrawn from the well $\left(84,000 \mathrm{ft}^{3} / \mathrm{d}\right)$ was from leakage, less than 1 percent $\left(400 \mathrm{ft}^{3} / \mathrm{d}\right)$ was from storage, and about 80 percent $\left(330,000 \mathrm{ft}^{3} / \mathrm{d}\right)$ was from boundary flow. 


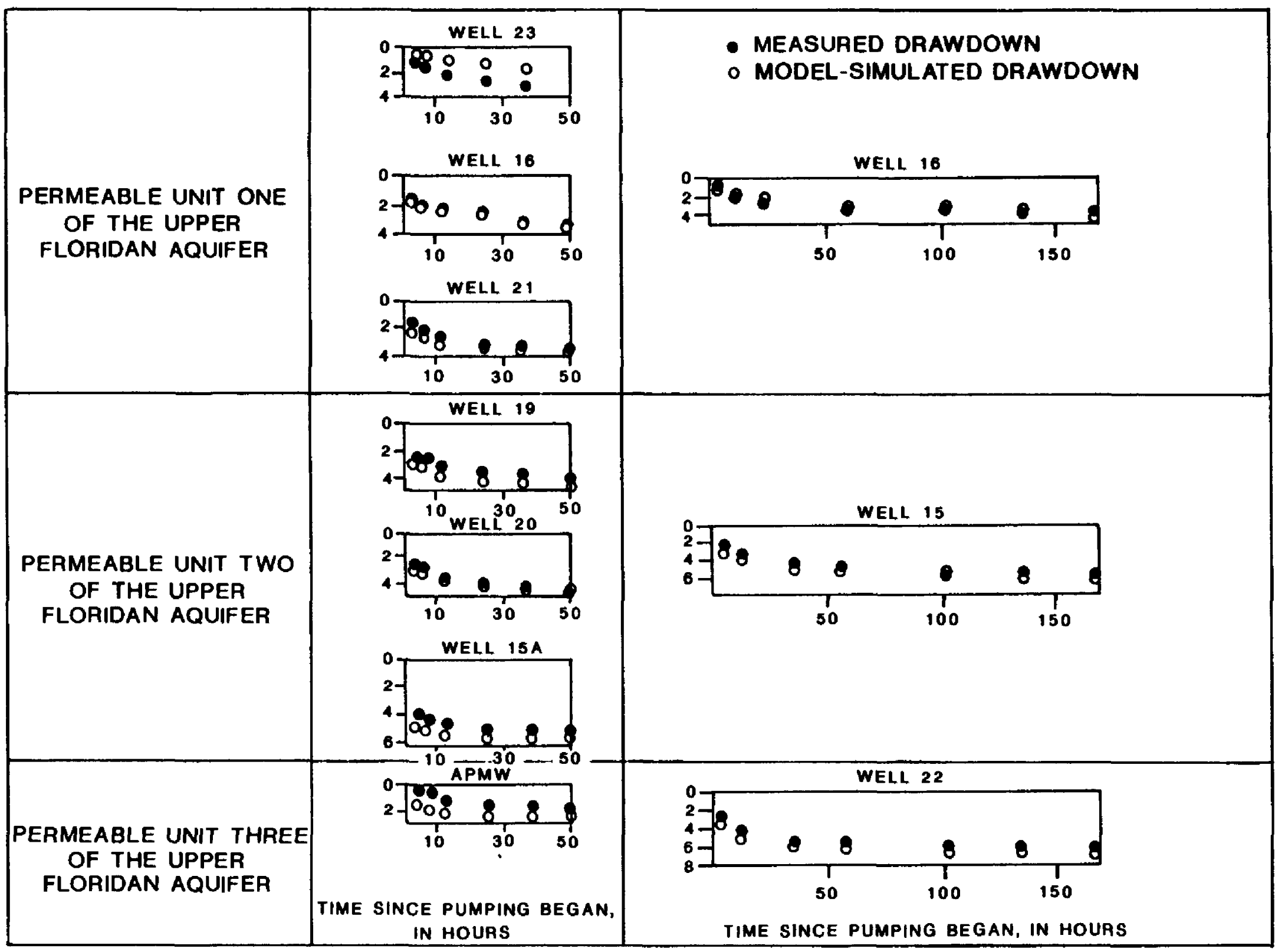

VERTICAL SCALE REPRESENTS DRAWDOWN, IN FEET

Figure 21. Measured and model-simulated water-level drawdowns at the old Tampa well field for aquifer tests of July and December 1990.

Simulation of the aquifer tests at the site with the transient numerical model indicates that the modeled equivalent porous medium response to pumping differs significantly from the observed response during the first 1 to 2 hours after pumping began, but matched the remaining time response reasonably well. The probable reason is that early-time drawdown in the aquifer is affected by ground-water flow through. secondary porosity features, such as vugs and fractures, that were not modeled. However, as the cone of depression developed around the pumped well, secondary porosity features represented smaller and smaller percentages of the total stressed volume of aquifer, and the total system responded regionally as an equivalent porous medium as simulated in the model. The transient cali- bration of the model indicates that the ground-water flow system at the old Tampa well field can be modeled as layered and horizontally homogeneous and isotropic on a local scale. The time required for the aquifer to respond to pumping as an equivalent porous medium probably depends on the percentage of effective secondary porosity in the stressed interval, the withdrawal rate, and the permeability and storage properties of the stressed interval. It was concluded that the model simulation of water-level declines in response to pumping was reasonably accurate (fig. 21).

Numerical modeling of ground-water flow tested the conceptualized hydrogeologic model of the Upper Floridan aquifer at the old Tampa well field. Results of steady-state and transient simulations of onsite aquifer 
Table 8. Water budgets for the Upper Floridan aquifer for steady-state and transient simulations of 50-hour and 168-hour aquifer tests at the old Tampa well field in June and December 1990

$\left[\mathrm{ft}^{3} / \mathrm{d}\right.$, cubic feet per day]

\begin{tabular}{|c|c|c|c|c|c|c|}
\hline & \multicolumn{2}{|c|}{$\begin{array}{l}\text { Steady-state conditions } \\
\text { with no pumping }\end{array}$} & \multicolumn{2}{|c|}{$\begin{array}{l}\text { Steady-state } \\
\text { simulation }\end{array}$} & \multicolumn{2}{|c|}{$\begin{array}{l}\text { Transient Simulation } \\
\text { (end of last time step) }\end{array}$} \\
\hline & $\begin{array}{c}\mathrm{ft}^{3} / d \\
(x 1,000)\end{array}$ & Percent & $\begin{array}{c}f t^{3} / d \\
(x 1,000)\end{array}$ & Percent & $\begin{array}{c}f t^{3} / d \\
(x 1,000)\end{array}$ & Percent \\
\hline $\begin{array}{l}\text { June } 1990 \\
\text { Inflow }\end{array}$ & & & \multicolumn{4}{|c|}{$50-$ hour aquifer test, pump well 15 , at $189,000 \mathrm{ft}^{3} / \mathrm{d}$ Inflow } \\
\hline Storage & 0 & 0 & 0 & 0 & 4 & 0.5 \\
\hline Head dependant boundaries & 632 & 94 & 709 & 90 & 707 & 89.5 \\
\hline Leakage from surficial aquifer system & 44 & 6 & 79 & 10 & 79 & 10 \\
\hline Total & $\overline{676}$ & $\overline{100}$ & 788 & $\overline{100}$ & $\overline{790}$ & 100 \\
\hline \multicolumn{7}{|l|}{ Outflow } \\
\hline Storage & 0 & 0 & 0 & 0 & 0 & 0 \\
\hline Head dependant boundaries & 676 & 100 & 599 & 76 & 601 & 76 \\
\hline Pumpage & 0 & 0 & 189 & 24 & 189 & 24 \\
\hline Total & $\overline{676}$ & 100 & 788 & $\overline{100}$ & 790 & $\overline{100}$ \\
\hline December 1990 & & & \multicolumn{4}{|c|}{ 168-hour aquifer test, pump APPW, at $414,000 \mathrm{ft}^{3} / \mathrm{d}$ Inflow } \\
\hline Inflow & & & & & & \\
\hline Storage & 0 & 0 & 0 & 0 & 0.4 & 0 \\
\hline Head dependant boundaries & 637.5 & 95 & 828 & 91 & 828 & 91 \\
\hline Leakage from surficial aquifer system & 33.5 & 5 & 84 & 9 & 84 & 9 \\
\hline Total & 671 & $\overline{100}$ & $\overline{912}$ & 100 & $\overline{912.4}$ & $\overline{100}$ \\
\hline \multicolumn{7}{|l|}{ Outflow } \\
\hline Storage & 0 & 0 & 0 & 0 & 0 & 0 \\
\hline Head dependant boundaries & 671 & 100 & 498 & 55 & 498.4 & 54.6 \\
\hline Pumpage & 0 & 0 & 414 & 45 & 414 & 45.4 \\
\hline Total & $6 \pi$ & $\overline{100}$ & $\overline{912}$ & $\overline{100}$ & $\overline{912.4}$ & 100 \\
\hline
\end{tabular}

tests indicate that the transmissivity of the Upper Floridan aquifer at the study site is about $60,000 \mathrm{ft}^{2} / \mathrm{d}$ with the upper $400 \mathrm{ft}$ of the aquifer accounting for about $20,000 \mathrm{ft}^{2} / \mathrm{d}$ of the total. The storage coefficient is on the order of $10^{-4}$. Additional information on the hydraulic properties of the upper $400 \mathrm{ft}$ of the Upper Floridan aquifer was collected using tracer tests.

\section{Analysis of Model Water Budgets}

Water budgets for the Upper Floridan aquifer for the steady-state and transient-model simulations were analyzed to determine the sources of water for the pumpage (table 8), to determine if the sources of water indicated by the water budgets of the model were consistent with the conceptual hydrogeologic model and were supported by observed data, and to check the volumetric calibration of the model. The water budget of the steady-state numerical model, with no pumping, was compared to the water budget of the Upper Floridan aquifer at the study site estimated using flownet analysis. The model calculated about $44,000 \mathrm{ft}^{3} / \mathrm{d}$ of water entering the Upper Floridan aquifer by vertical leakage through the quasi-three-dimensional confining unit. About $632,000 \mathrm{ft}^{3} / \mathrm{d}$ of water entered and about $676,000 \mathrm{ft}^{3} / \mathrm{d}$ left the model through general head boundaries. This compares well with the water budget of the Upper Floridan aquifer estimated using flow-net analysis in which flow through the Upper Floridan aquifer was estimated to be about $690,000 \mathrm{ft}^{3} / \mathrm{d}$; leakage from the surficial aquifer system accounts for approximately $62,000 \mathrm{ft}^{3} / \mathrm{d}$ of that total. These estimates were based on a 5 - $\mathrm{ft}$ head difference between the surficial aquifer system and the Upper Floridan aquifer, a leakance coefficient of 0.00033 for the intermediate confining unit, a transmissivity of $63,000 \mathrm{ft}^{2} / \mathrm{d}$ for the Upper Floridan aquifer, and a head gradient of $0.0016 \mathrm{ft} / \mathrm{ft}$ across the area. 
The water budgets of the steady-state model with no pumpage for the conditions in June and December 1990 and of the model for the 50-hour and 168-hour aquifer tests were analyzed to determine the effects of withdrawal of water from the model layers simulating the Upper Floridan aquifer on leakage from the model layer simulating the surficial aquifer system. Withdrawal of water from model layers 2 and 4 (50-hour test) induced an additional $35,000 \mathrm{ft}^{3} / \mathrm{d}$ of downward leakage from model layer 1 through the quasi-threedimensional confining unit. Leakage from layer 1 accounted for about 42 percent of the pumpage. Withdrawal of water from model layer 6 (168-hour test) induced an additional $50,000 \mathrm{ft}^{3} / \mathrm{d}$ of downward leakage from model layer 1 through the quasi-threedimensional confining unit. Leakage from layer 1 accounted for about 20 percent of the pumpage.

The water in the Upper Floridan aquifer in Hillsborough County is ultimately derived by leakage, but the model budgets indicate that the deeper test had less effect on leakage within the modeled area than did the shallow test. The distribution of sources of water indicated by the model simulations is supported by the data collected during aquifer tests at the site. The water level in shallow well 16 , completed in the intermediate confining unit and located about $700 \mathrm{ft}$ from well 15 , declined $2.4 \mathrm{ft}$ after 48 hours of pumping well 15 at a rate of $980 \mathrm{gal} / \mathrm{min}$; however, the water level in shallow well 16, located about $75 \mathrm{ft}$ from the Avon Park production well, declined only $1.4 \mathrm{ft}$ after 48 hours of pumping the Avon Park production well at a rate of 2,150 $\mathrm{gal} / \mathrm{min}$.

The differences between model water budgets for the transient simulations of the two aquifer tests indicate the effects of pumping different model layers, with different hydraulic properties, at different rates. Model layers 2,3 , and 4 collectively have about half the transmissivity of model layer 6 , slightly higher storage coefficient values, and a better hydraulic connection to model layer 1 . As a result, a greater percentage of the pumpage is supplied by leakage from layer 1 when model layers 2, 3, and 4 are pumped, there is greater withdrawal from storage, and there are fewer contributions from the general head boundaries than when pumping model layer 6 .

Analysis of the model water budgets for steadystate and transient simulations of the same aquifer test (table 8) indicates the transient simulation had approached steady-state conditions by the end of the last time step. By the end of the last time step for the 50-hour and 168-hour tests, less than 1 percent of the water budget for the Upper Floridan aquifer was being supplied by withdrawal from storage. Examination of the water budgets for the various simulations indicates that the source of water to the model layers representing the Upper Floridan aquifer is primarily the general head boundary cells, indicating that ground-water flow through the study site is predominately horizontal. The sources of water indicated by the water budgets of the various simulations are consistent with the conceptual hydrogeologic model. It was concluded that the model provides a reasonable approximation of ground-water flow through the Upper Floridan aquifer at the study site.

\section{Sensitivity Analysis}

A sensitivity analysis of the numerical model of the ground-water flow system at the old Tampa well field was made using the drawdown calculated for the Upper Floridan aquifer by the calibrated steady-state model simulation of the 50-hour aquifer test. This analysis provided information on the relative sensitivity of the model to changes in values of the estimated hydraulic parameters. The sensitivity of the model was tested by making tenfold changes in the leakance coefficients, twofold changes in transmissivity of the Upper Floridan aquifer and general head boundary conductance, and conversion to no-flow and specified-head boundary conditions. One parameter at a time was changed, noting the effect on the drawdown simulated in the Upper Floridan aquifer. The model was considered to be sensitive to a parameter if the change in the parameter produced more than $1 \mathrm{ft}$ of change in the mean drawdown over the 784 model nodes, or increased the range of drawdown values more than $5 \mathrm{ft}$, or both. Results of sensitivity analyses are summarized in table 9.

Analyses indicated that the model is relatively sensitive to changes in the transmissivity of the Upper Floridan aquifer and the boundary conditions. Flow through the model layers is predominately horizontal; therefore, the model is relatively insensitive to changes in the vertical conductance values of the model layers representing the leakage coefficients of the intermediate confining unit and the Upper Floridan aquifer. The vertical conductance terms used for model layers 4,5 , and 6 cannot be adequately tested with this method, which is consistent with the interpretation of the computed water budgets of the model simulations of the aquifer tests. 
Table 9. Results of model sensitivity analysis based on simulation of the 50-hour aquifer test [NA, not applicable]

\begin{tabular}{|c|c|c|c|c|c|c|c|}
\hline \multirow{3}{*}{$\begin{array}{c}\text { Input } \\
\text { parameter }\end{array}$} & \multirow{3}{*}{$\begin{array}{c}\text { Factor } \\
\text { changa in } \\
\text { parametar }\end{array}$} & \multicolumn{6}{|c|}{ Range and mean of drawdown in 784 model nodes, in faat } \\
\hline & & \multicolumn{2}{|c|}{ Model layer 2} & \multicolumn{2}{|c|}{ Modal layer 4} & \multicolumn{2}{|c|}{ Model layar 6} \\
\hline & & Range & Mean & Ranga & Mean & Range & Mean \\
\hline Steady-state calibration & NA & $1.4-10.4$ & 3.4 & $1.4-10.3$ & 2.9 & $1.4-2.0$ & 1.8 \\
\hline $\begin{array}{l}\text { Vertical conductance of } \\
\text { layer } 1\end{array}$ & $\begin{array}{r}(0.1) \\
(10.0)\end{array}$ & $\begin{array}{l}1.9-11.1 \\
0.3-8.4\end{array}$ & $\begin{array}{l}4.0 \\
1.7\end{array}$ & $\begin{array}{l}1.7-10.7 \\
0.8-9.5\end{array}$ & $\begin{array}{l}3.2 \\
2.1\end{array}$ & $\begin{array}{r}1.62 .3 \\
=0.8-1.3\end{array}$ & $\begin{array}{l}2.1 \\
1.1\end{array}$ \\
\hline $\begin{array}{l}\text { Vertical conductance of } \\
\text { layers } 2 \text { through } 5\end{array}$ & $\begin{array}{r}(0.1) \\
(10.0)\end{array}$ & $\begin{array}{l}1.8-10.9 \\
1.4-9.6\end{array}$ & $\begin{array}{l}3.8 \\
2.9\end{array}$ & $\begin{array}{l}1,8-11.7 \\
1.4-9.2\end{array}$ & $\begin{array}{l}3.8 \\
2.6\end{array}$ & $\begin{array}{l}1.0-1.4 \\
1.4-2.6\end{array}$ & $\begin{array}{l}1.3 \\
2.1\end{array}$ \\
\hline $\begin{array}{l}\text { Transmissivity of layers } \\
2 \text { through } 6\end{array}$ & $\begin{array}{l}(0.5) \\
(2.0)\end{array}$ & $\begin{array}{l}1.2-18.6 \\
1.6-6.1\end{array}$ & $\begin{array}{l}4.7 \\
2.6\end{array}$ & $\begin{array}{l}1.4-18.3 \\
1.5-6.2\end{array}$ & $\begin{array}{l}3.9 \\
2.4\end{array}$ & $\begin{array}{l}1.3-2.7 \\
1.4-1.7\end{array}$ & $\begin{array}{l}2.2 \\
1.6\end{array}$ \\
\hline $\begin{array}{l}\text { General head boundary } \\
\text { conductance }\end{array}$ & $\begin{array}{l}(0.5) \\
(2.0)\end{array}$ & $\begin{array}{l}2.5-11.4 \\
0.8-9.7\end{array}$ & $\begin{array}{l}4.4 \\
2.7\end{array}$ & $\begin{array}{l}2.6-11.6 \\
0.7-9.7\end{array}$ & $\begin{array}{l}4.1 \\
2.2\end{array}$ & $\begin{array}{l}2.6-3.2 \\
0.6-1.3\end{array}$ & $\begin{array}{l}3.0 \\
1.1\end{array}$ \\
\hline $\begin{array}{l}\text { No-flow boundary for } \\
\text { layers } 2 \text { through } 6\end{array}$ & NA & $17.8-26.2$ & 19.5 & $20.5-29.1$ & 21.9 & $20.7-21.0$ & 20.9 \\
\hline $\begin{array}{l}\text { Specified head boundary } \\
\text { for layers } 2 \text { through } 6\end{array}$ & NA & $0.1-8.9$ & 2.1 & $0.02-8.8$ & 1.6 & $0.01-0.4$ & 0.3 \\
\hline
\end{tabular}

The sensitivity analyses indicated that estimates of the transmissivity of the Upper Floridan aquifer were reasonable approximations of the hydraulic conditions at the site. However, the leakance coefficient of the intermediate confining unit could be in error by as much as an order of magnitude. Sensitivity analyses indicated that using no-flow boundary conditions for the Upper Floridan aquifer will cause the model to greatly overestimate the drawdown and using specified head boundaries for the Upper Floridan aquifer results in measurable underestimates of the drawdown.

\section{Limitations of the Model Analysis}

The numerical model is a simplified mathematical approximation of the hydrogeologic model, which is in turn a simplified conceptual approximation of a finite volume of the ground-water flow system at the old Tampa well field. A numerical model will not provide accurate predictions on a scale finer than the separation of the data points used to build the model. The model should be used only for the finite area where the hydrogeology has been defined.

Knowledge of the spatial variation of aquifer characteristics is usually unknown or limited in extent, and it is common to assume uniform properties by default. The individual layers of the aquifer were assumed to be uniformly porous, although field observations indicate otherwise. This assumption is justified because aquifer response to pumping was shown to approximate that of a uniformly porous medium within $20 \mathrm{~min}$ after pumping began. Generally, a simple model is preferred over a more complex one.

The upper $550 \mathrm{ft}$ of the Upper Floridan aquifer was divided into two permeable units (model layers 2 and 4) and two semiconfining units (model layers 3 and 5). The remaining thickness of the Upper Floridan aquifer was not differentiated into permeable and less permeable layers. The aquifer is probably stratified throughout its thickness, but there are no data to use as a basis for further subdivision of the aquifer for depths more than $800 \mathrm{ft}$ below land surface. The model, therefore, might not accurately represent the lower $550 \mathrm{ft}$ of the Upper Floridan aquifer.

The leakance coefficient of the semiconfining unit between permeable units two and three of the Upper Floridan aquifer is not well quantified at the old Tampa well field. The vertical hydraulic conductivities used to calculate the vertical conductance for model layers 4,5 , and 6 were not estimated from core samples collected onsite as were those for model layers 2 and 3.

This model is not intended as a management tool. The accuracy of the model simulation of aquifer response to stress at the old Tampa well field is limited to the conditions under which the model was calibrated. The model might not provide accurate simulation results under greatly different conditions. 


\section{TRACER TESTS}

Test drilling and borehole geophysical data confirmed the presence of secondary porosity in the Upper Floridan aquifer at the study site. Tracer tests were conducted to investigate the importance of ground-water flow through secondary porosity and to collect additional hydrogeologic information about the aquifer. Salt (sodium chloride) and Rhodamine WT fluorescent dye were used as tracers. Salt was used for short-term tests over small horizontal distances (less than 24 hours and less than $25 \mathrm{ft}$ ). Rhodamine WT fluorescent dye was used for long-term tests over horizontal distances of up to $200 \mathrm{ft}$ because it is detectable at concentrations as low as $0.1 \mathrm{ppb}$.

\section{Techniques of Tracer Testing}

Tracer tests were conducted by injecting salt or dye into an open-hole interval of an Upper Floridan aquifer well. The movement of the ground water induced by pumping well 15 at a rate of about $980 \mathrm{gal} / \mathrm{min}$ was then measured. Tracers were injected using two different methods: (1) circulation of water in the injection well to achieve an even mixture of tracer and (2) pulse injection using a drop pipe to disperse tracer throughout a specific depth interval or at a specific depth below land surface.

The rate and direction of water movement in the aquifer were determined by measuring the change in tracer concentration in the water. Initial tests involved injecting salt into well 11. Static and pumping fluidresistivity logs were run in the injection well and in the pumped well to establish baseline conditions. A fluid-resistivity $\log$ was run in well 11 after the injection of salt to determine the placement of the tracer in the well bore. Multiple fluid-resistivity logs were run in wells 11 and 15 during the pumping of well 15 to monitor the movement of salty water from the injection well to well 15. Subsequent tests involved injecting Rhodamine WT into wells 11 and 20.

The movement of ground-water spiked with Rhodamine WT was determined by measuring the dye concentration in water in the injection well, in well 11 between the injection well and the pumped well, and in the water discharged from the pumped well. Groundwater samples were collected from the injection well at discrete depth intervals for 48 hours after the test began to determine the rate of depletion of dye and from well 11 every 2 to 3 days to measure the vertical distribution of dye concentration in the upper $400 \mathrm{ft}$ of the Upper
Floridan aquifer. Dye concentration in water discharged from the pumped well was measured continuously using a fluorometer fitted with a flow-through chamber and was recorded every 5 min by an onsite computer interfaced with the fluorometer.

The fluorometer used to measure the concentration of Rhodamine WT was calibrated before each test with standards of $0-, 1-$, and 10-ppb concentration. The fluorometer is sensitive to fluctuations in ambient air temperature, which ranged from about 21 to $35^{\circ} \mathrm{C}$ during the tests. A higher instrument temperature results in a higher indicated tracer concentration. Inspection of temperature data and dye concentration indicated that temperature fluctuations of less than $5^{\circ} \mathrm{C}$ did not measurably alter indicated dye concentration. Test data were interpreted using dye concentrations that were measured when the instrument temperature was within a range of $2{ }^{\circ} \mathrm{C}$ to compensate for the daily fluctuation of temperature.

\section{Preliminary Tests}

Several short-term tracer tests were used to determine where water enters the borehole of the pumped well and to determine the direction of flow in well 11 , $25 \mathrm{ft}$ east of the pumped well. Flowmeter logs of well 11 , which was drilled to $750 \mathrm{ft}$ and cased to a depth of $74 \mathrm{ft}$, indicated upward flow in the borehole from permeable unit three as a result of pumping well 15 , which is $415 \mathrm{ft}$ deep with $67 \mathrm{ft}$ of casing and open only to permeable units one and two. A well plug was installed at a depth of $422 \mathrm{ft}$ in well 11 to eliminate this flow before the long-term tracer tests were conducted. This was done so that all of the water pumped from well 15 would come from the section of the aquifer in which the tracer was placed, which was necessary for accurate calculations of the porosity of the aquifer matrix using tracer travel time to the pumped well. Subsequent flowmeter logging detected no vertical flow in the bottom of well 11 when well 15 was pumped, but tracer tests indicated that upward flow of water still occurred in well 11 when well 15 was pumped.

Rhodamine WT or salt was injected into well 11 at specific depths below land surface during the tracer tests. In the first test, Rhodamine WT was injected into well 11 at a depth of $80 \mathrm{ft}$ below land surface. Well 15 was then pumped at a rate of $980 \mathrm{gal} / \mathrm{min}$. The arrival of dye at the pumped well through a single 1- to 2 -in.diameter vug was visible with a borehole video camera. The dye traveled between the two wells in about 60 


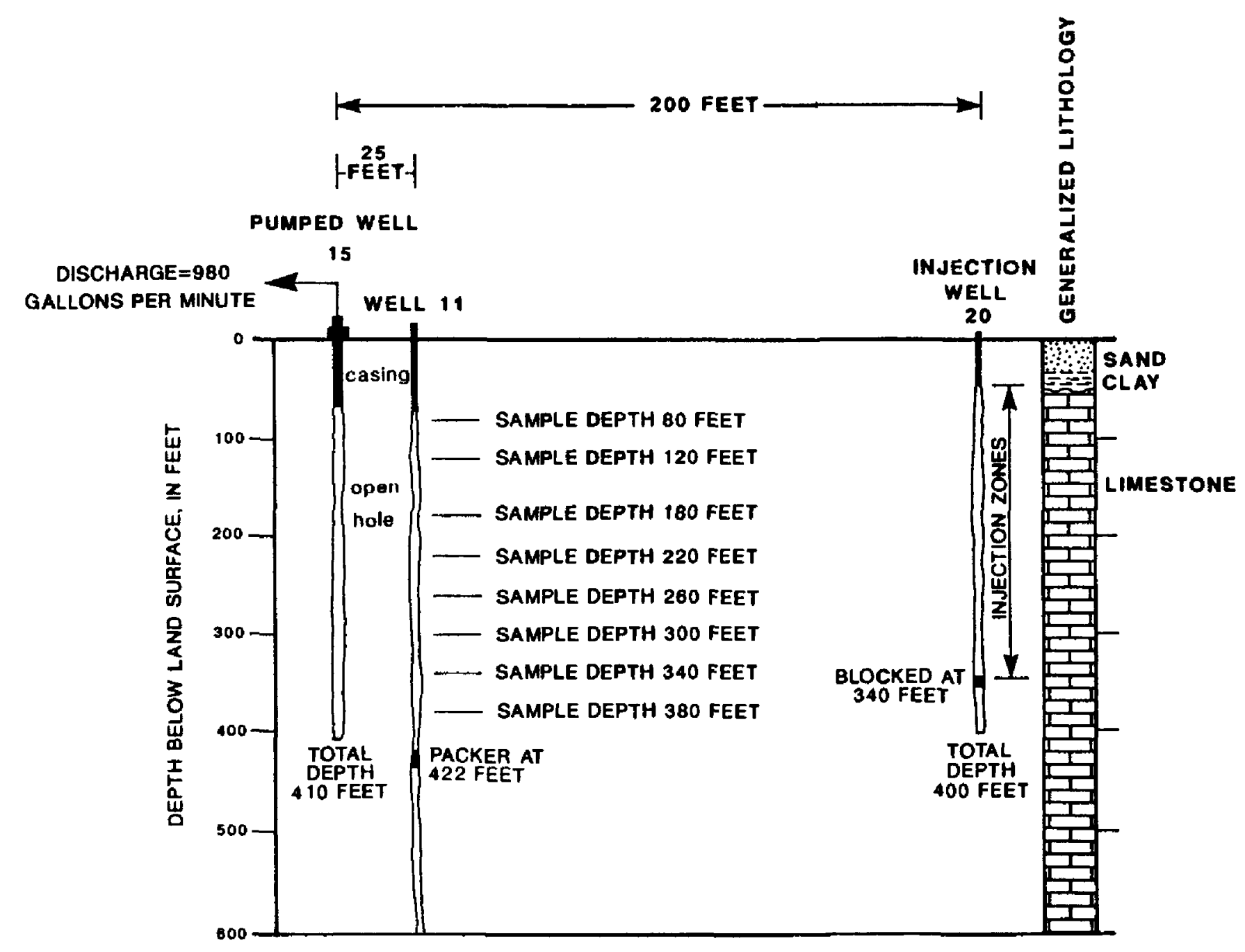

Figure 22. Tracer injection and withdrawal system at the old Tampa well field.

seconds, which indicates a direct hydraulic connection between wells 11 and 15 at about $82 \mathrm{ft}$ below land surface. Subsequent tests using salt as the tracer confirmed the inflow of water to the pumped well at $82 \mathrm{ft}$ below land surface.

Additional tracer tests were conducted by injecting salt in well 11 at a depth of $380 \mathrm{ft}$ below land surface and monitoring the upward movement of salty water in the well bore as well 15 was pumped. Salty water from a depth of $380 \mathrm{ft}$ in well $11 \mathrm{did}$ not rise above a depth of $80 \mathrm{ft}$ below land surface. Fluid resistivity logging indicated that salty water from well 11 entered well 15 at $82 \mathrm{ft}$ below land surface within 30 min after pumping of well 15 began. These data indicate that, as a result of preferential flow at a depth of about $80 \mathrm{ft}$, water flows upward from the bottom of well 11 to the zone of preferential flow and then laterally to the pumped well.

\section{Deep Test}

The first long-term tracer test at the old Tampa well field involved injecting $1.32 \mathrm{~L}$ of 20 -percent solution ( $314 \mathrm{~g}$ ) Rhodamine WT dye into well 20 that is $200 \mathrm{ft}$ east of the pumped well and $175 \mathrm{ft}$ east of well 11. The borehole of well 20, originally drilled to a depth of 400 $\mathrm{ft}$, was blocked at $340 \mathrm{ft}$ below land surface. Dye was circulated in the open borehole by pumping groundwater through a drop pipe from a depth of $340 \mathrm{ft}$, spiking the water with dye, and injecting the spiked water into well 20 through another drop pipe inserted to a depth of $40 \mathrm{ft}$ below land surface. The injection process was terminated when the water pumped from $340 \mathrm{ft}$ below land surface contained dye. Pumping of well 15 was then begun. Simultaneous measurements of water levels in the injection well and the pumped well indicated that the drawdown cone became steady-shape within 20 min of the start of pumping. Well 15 was to be pumped continuously until the dye had been completely purged from the aquifer; however, a pump malfunction interrupted the test after about 50 hours and periodically thereafter throughout the 124-day test. Well 15 was pumped at a rate of about $980 \mathrm{gal} / \mathrm{min}$ for 70 percent of the time ( 87 out of 124 days) during the period from July 18, 1990, to November 18, 1990.

Movement of dye was monitored in three wells (fig. 22). Dye concentration was measured periodically in samples collected with a thief sampler from well 20 at depths of $80,120,180,260$, and $290 \mathrm{ft}$ below land 
surface to calculate the rate of dye depletion in the injection well. The dye concentration in samples collected from drop pipes in well 11 at depths of 80,120 , $180,220,260,300,340$, and $380 \mathrm{ft}$ below land surface was measured periodically to determine the vertical distribution of dye at a point between the injection well and the pumped well. Dye concentration in water discharged from the pumped well was measured continuously to determine arrival time, peak concentration, persistence time, and total mass recovered.

The concentration of dye in water pumped from well 15 as a function of time is illustrated in figure 23 . The pump did not operate continuously for the entire test; therefore, the periods of pump shutdown were discounted when calculating dye travel time. The discontinuous pumping probably had two effects on the dye arrival: (1) it delayed the arrival time and the time to peak concentration of secondary dye peaks, and (2) it lowered the peak concentration of later arrivals by dispersing the dye. As a result, computed porosity values based on arrival time of those peak dye concentrations could be overestimated. The first arrival time of the dye was 3.6 hours after pumping began, and the time to peak dye concentration was 15 hours. Persistence time of the dye concentration greater than $0.3 \mathrm{ppb}$ was 50 hours. A second dye arrival occurred after 36 days of pumping. Time to peak dye concentration for the second arrival was 48 days. Persistence time following the second arrival was 18 days. Third and fourth dye arrivals occurred after 70 and 79 days of pumping, respectively. The persistence times of the third and fourth dye arrivals were 1 to 2 days; however, it was difficult to determine these persistence times because the relative increase in dye concentration was small. The persistence time for the entire test was greater than the 87 days of pumping. About $69 \mathrm{~g}$ ( 22 percent) of the dye was recovered.

Dye concentration in ground-water samples collected from drop pipes in well 11 also was measured periodically during the test. Dye was detected in samples collected from $380 \mathrm{ft}$ below land surface, $40 \mathrm{ft}$ below the depth of the open-hole interval of the injection well. The presence of dye at this depth indicates that the injection well is blocked but not plugged at $340 \mathrm{ft}$ below land surface, or that there is significant leakage through the semiconfining unit separating permeable units one and two.

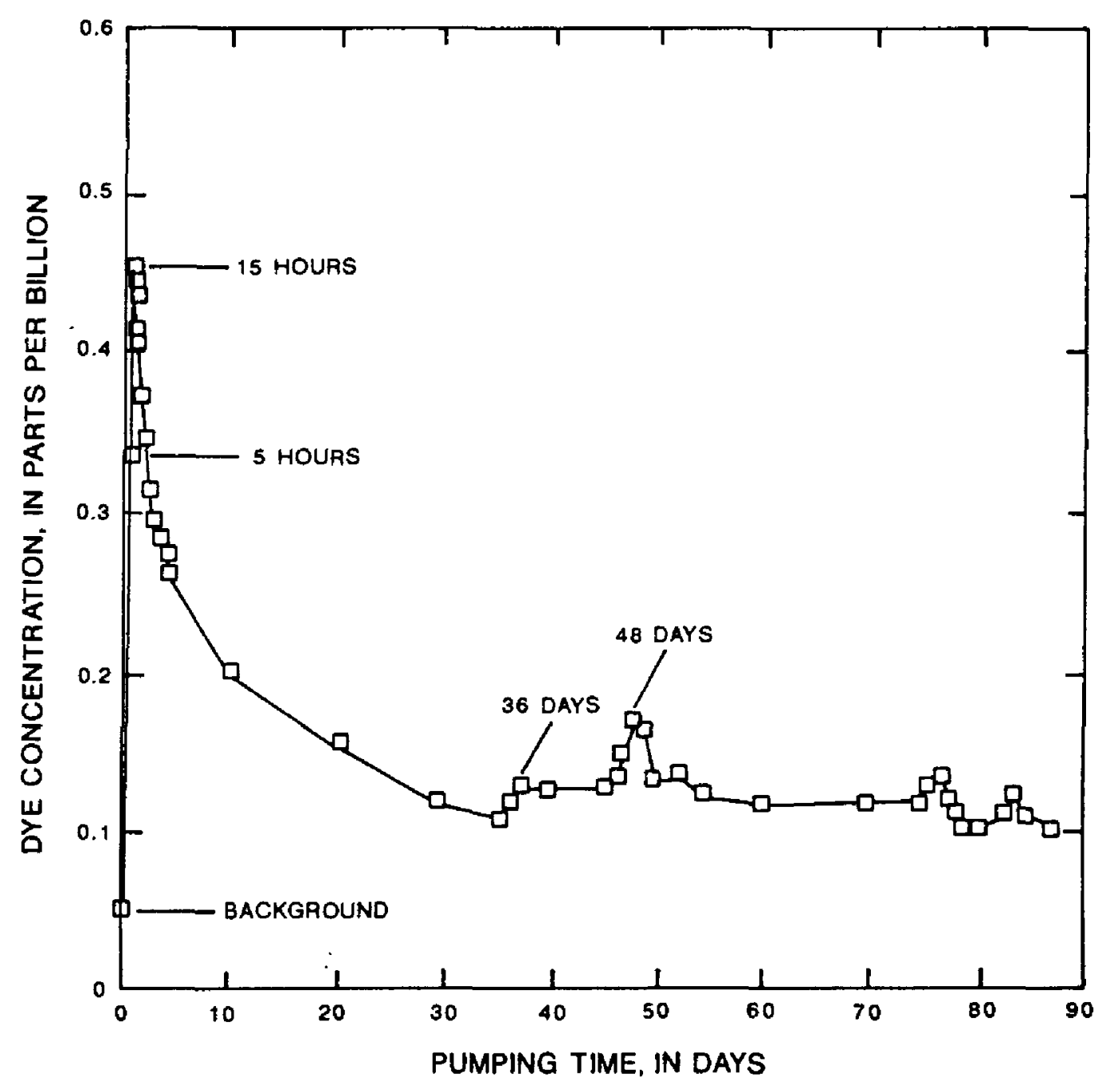

Figure 23. Dye-concentration curve for well 15 during the Rhodamine WT dye test ending November 18, 1990. 


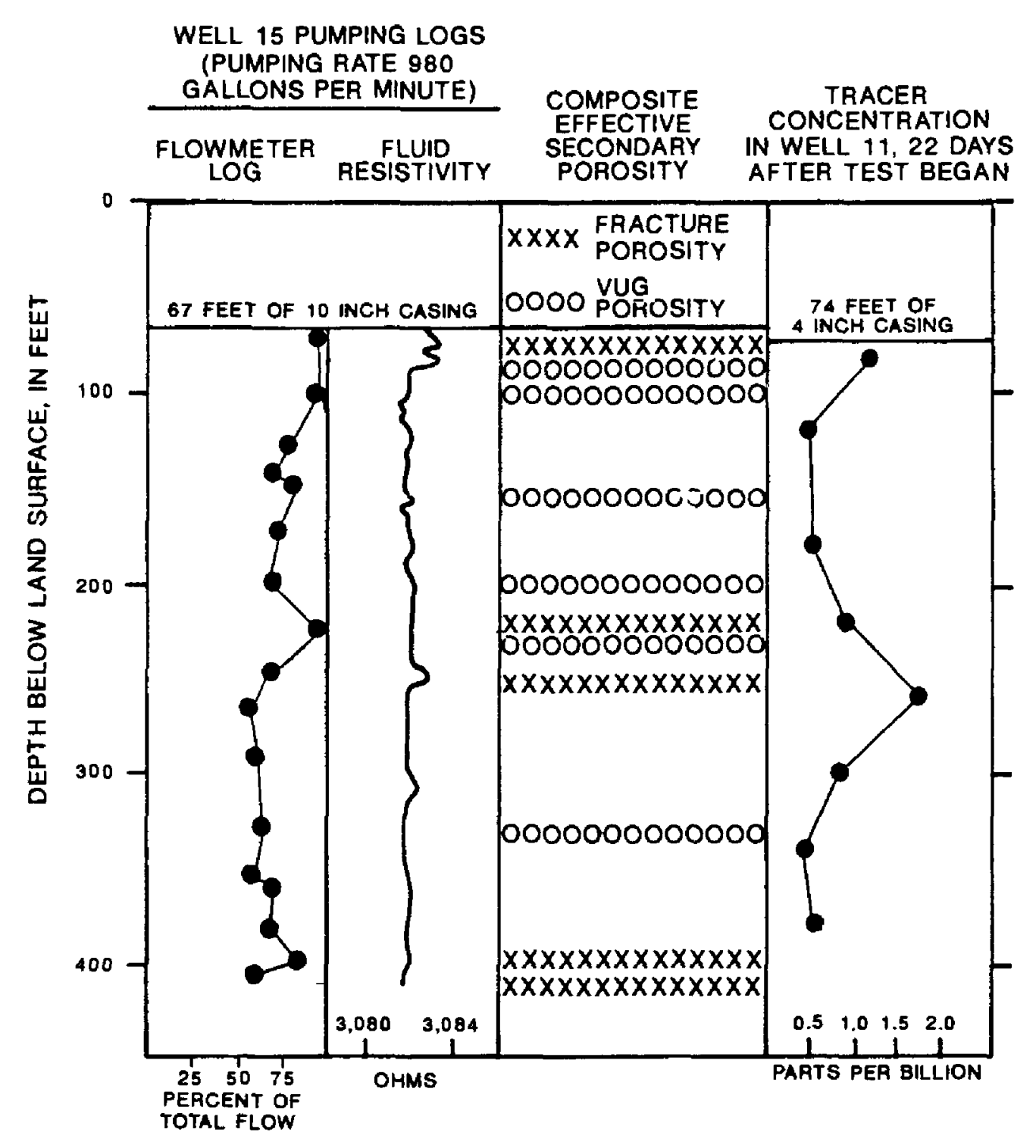

Figure 24. Correlation between effective secondary porosity and tracer concentration in well 11 at the old Tampa well field.

A correlation exists between elevated dye concentration in samples collected from drop pipes in well 11 and effective fracture porosity (fig. 24). There are two possible explanations for the increased dye concentration in zones of effective fracture porosity. The first is that ground water in the zones of effective fracture porosity moves along a more direct path than ground water in the aquifer matrix. The dye would be less dilute as a result. Another explanation is that less sorption of the dye occurs in zones of effective fracture porosity because the surface area of the aquifer exposed to the water is smaller, which would result in a larger relative concentration of dye in conduit flow zones.

\section{Shallow Test}

A second test using well 20 as the injection well was initiated after the Rhodamine WT concentration in water discharged from well 15 decreased to $0.08 \mathrm{ppb}$, which was near the background level of $0.05 \mathrm{ppb}$. The test was conducted to determine how a contaminant introduced into the upper permeable unit of the Upper Floridan aquifer might move to a pumped well. First, a plug was installed in the injection well at a depth of $90 \mathrm{ft}$, making the open-hole interval 39 to $90 \mathrm{ft}$ below land surface. Pumping of well 15 began several days prior to dye injection, not only to further purge the previously introduced dye from the aquifer, but also to establish a steady-state flow field in the vicinity of the injection well. For the shallow test, $1.9 \mathrm{~L}$ of 20 -percent solution (452 g) Rhodamine WT dye was introduced into well 20 from 39 to $90 \mathrm{ft}$ below land surface using the pulse method. This method involved inserting a drop pipe to $90 \mathrm{ft}$ below land surface in the injection well. The dye was poured into the drop pipe and followed with the volume of water required to place the slug of dye in the drop pipe from 39 to $90 \mathrm{ft}$ below land surface. Removing the drop pipe left a column of dye in the open-hole interval of the injection well. 
Well 15 was pumped at a rate of about $980 \mathrm{gal} / \mathrm{min}$. The pump stopped periodically, as it did during the first test. From the startup on February 7 to shutdown on April 6, the pump ran 89 percent of the time (5l out of 57 days). The concentration of dye as a function of time in water pumped from well 15 is shown in figure 25 . The first arrival time of dye was 5 hours. Dye concentration stabilized after 9 days, but did not decline. A second dye arrival was indicated at 15 days, and a third arrival occurred after 43 days of pumping. The peak concentration and persistence time could not be determined because the pump failed before the dye concentration had peaked. About $50 \mathrm{~g}$ (11 percent) of the dye was recovered.

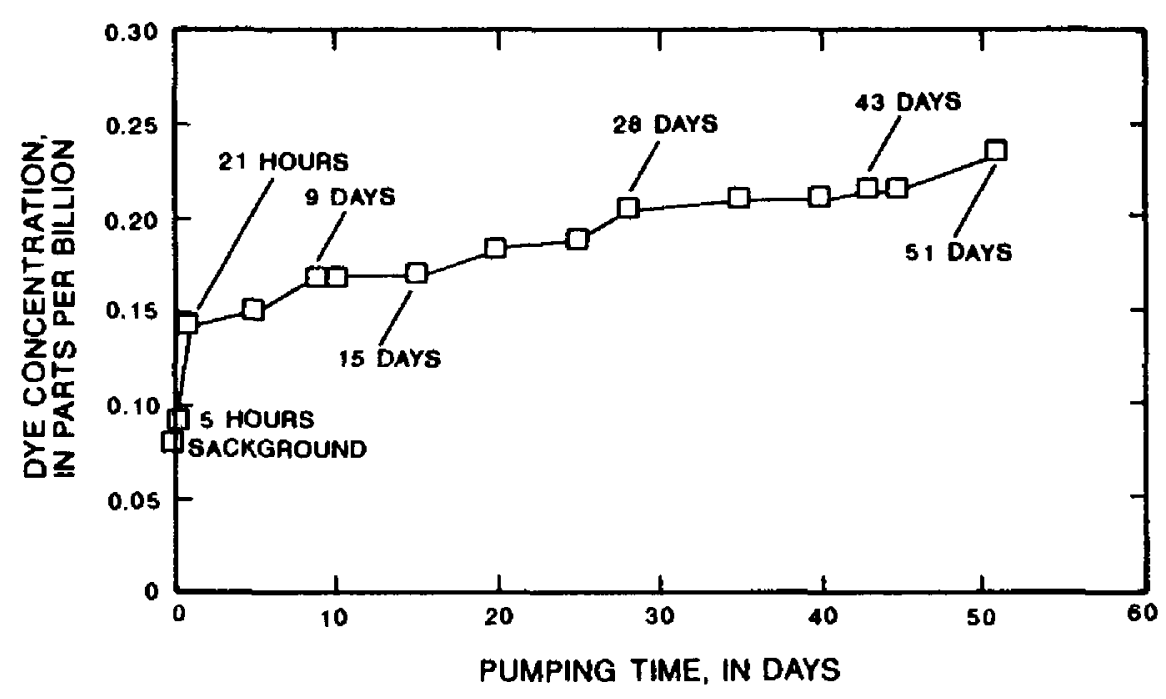

Figure 25. Dye-concentration curve for well 15 during the Rhodamine WT dye test ending April 6, 1991.

\section{Analysis of Tests}

Analysis of the dye test data was complicated by the low recovery percentage and the multiple dye arrivals. Recent investigations of sorption of Rhodamine WT indicate that it is not totally conservative. Dye sorption tests performed by Sabatini and Austin (1991) indicate that the level of adsorption of Rhodamine WT dye increases with increasing valence and concentration of background cations. Adsorption of Rhodamine WT also increases in the presence of calcium chloride (Sabatini and Austin, 1991). The use of salt as a ground-water tracer during preliminary tests might have increased the sorption of the Rhodamine WT. Sorption probably had a significant role in attenuating the dye and reducing the amount of dye recovered; however, the shape of the tracer concentration curve as a function of time is more important than the percent recovery.
The multimodal distribution of dye arrival during the deep tracer test is representative of ground-water flow through different flow media. The rapid peak and decline of the initial dye arrival for the deep tracer test are consistent with flow through secondary porosity (Mull and others, 1988). The initial dye arrival represents the travel time and transport properties of the part of the aquifer having interconnected secondary porosity (solution conduits or fractures), possibly through the zone of effective vug porosity identified at $82 \mathrm{ft}$ below land surface in wells 15 and 11 during preliminary tracer tests and through the zone of effective fracture porosity identified at depths of 250 and $266 \mathrm{ft}$ below land surface in wells 15 and 15A using geophysical logs and borehole videos (figs. 9 and 10). The secondary dye arrival is probably representative of the matrix flow arrival. The third and fourth dye arrivals (fig. 23) during the deep test probably do not represent significant components of flow in the aquifer because of the small increase in dye concentration and the short persistence time.

Interpretation of the shallow tracer test is complicated by the poor separation of the dye arrivals into distinct events. The rapid dye arrival at the pumped well can only be explained by ground-water flow through a conduit or fracture. The lack of a peak-and-decline cycle of dye concentration for the first dye arrival indicates that secondary porosity probably is a more important mechanism for ground-water flow in this part of the aquifer than it is in the aquifer as a whole.

Vugs are the dominant form of effective secondary porosity in the first $200 \mathrm{ft}$ of the Upper Floridan aquifer (fig. 10). Fracture porosity occurs primarily below 200 $\mathrm{ft}$ below land surface. The rapid rise and decline of dye concentration during the first dye arrival during the deep tracer test could be attributed to ground-water flow through fracture porosity. The shape of the dyeconcentration curve for the shallow tracer test might be more representative of ground-water flow through vug porosity.

The tracer test data were evaluated using the volumetric displacement method, a Laplace transform solution curve-matching method, and a tracer-dilution method to estimate the porosity, longitudinal dispersivity, and hydraulic conductivity of the aquifer. Each method assumes a uniformly porous aquifer. The results of the analyses are representative of only the aquifer matrix and could misrepresent conditions in a doubly porous aquifer. 


\section{Volumetric Displacement Method}

The effective porosity of the injected zone was estimated based on the time required to remove the volume of water in the aquifer between the injection well and the pumped well at the specified discharge rate. This is expressed as (Florida Department of Environmental Regulation, 1987):

$$
n_{e}=\frac{t Q}{\pi r^{2} h} \cdot 100
$$

where

$\mathrm{n}_{\mathrm{e}}$ is the effective porosity, in percent;

$t$ is the time required to replace the volume of water between the pumped well and the injection well (the time to peak tracer concentration), in days;

$\mathrm{Q}$ is the discharge rate, in cubic feet per day;

$r$ is the radius from the pumped well to the injection well, in feet; and

$h$ is the thickness of the injected zone, in feet.

The effective porosity of the aquifer for the deep tracer test, based on a 15-hour time to peak concentration, a discharge rate $(\mathrm{Q})$ of $980 \mathrm{gal} / \mathrm{min}$, a straight-line travel distance (r) of $200 \mathrm{ft}$, and an injected thickness (h) of $300 \mathrm{ft}$, is 0.3 percent. This porosity value is representative of the effective secondary porosity, possibly fracture porosity. Based on the time to the second tracer peak of 48 days, the discharge rate, and the distance to the injection well, the effective porosity of the aquifer matrix is 24 percent. This value is within the range of porosities measured in limestone cores collected from the Upper Floridan aquifer in southwestern Florida (table 4).

A similar analysis was performed for the shallow tracer test using a discharge rate equal to the volume of water flowing to the pumped well from the section of the aquifer injected, or $\mathrm{Q}=440 \mathrm{gal} / \mathrm{min} \times 1 / 4$ of the thickness of permeable unit one $=110 \mathrm{gal} / \mathrm{min}$, an injected thickness (h) of $51 \mathrm{ft}$, and $r=200 \mathrm{ft}$. The effective secondary porosity of the part of the aquifer tested is 0.3 percent, based on a 21 -hour time to peak concentration for the first arrival. The estimated effective porosity of the aquifer matrix is 14 percent, based on the arrival time of 43 days for the last tracer arrival. Because this estimate is made using an arrival time rather than a time to peak concentration, the porosity estimate represents a minimum value.

\section{Curve-Matching Method}

A Laplace transform solution for the injection of tracer in a well situated in a homogeneous aquifer with an existing steady-state, horizontal, radially convergent flow field (Moench, 1989) was used to estimate the effective porosity and longitudinal dispersivity of the aquifer using the results of the deep tracer test. The advection-dispersion equation for plane radial flow in a porous medium is used as the controlling equation (Moench, 1989).

$$
\frac{1}{r} \frac{\partial}{\partial r}\left[r D_{\mathrm{L}} \frac{\partial C}{\partial r}\right]-v \frac{\partial C}{\partial r}=R \frac{\partial C}{\partial t},
$$

where

$\mathrm{r}$ is the radial distance from the center of the pumped well to the point of interest, in feet;

$D_{L}$ is the coefficient of longitudinal hydrodynamic dispersion, in feet squared per day;

$\mathrm{C}$ is the tracer concentration in the aquifer at the time of interest averaged over the vertical surface of area $2 \pi \mathrm{rh}$, in parts per billion; where $h$ is the injected thickness, in feet;

$\mathrm{v}$ is the particle velocity, in feet per day;

$\mathrm{R}$ is the tracer retardation factor, dimensionless; and

$t$ is the time from the start of the tracer test, in days.

Estimates of aquifer matrix porosity and dispersivity are made using theoretical arrival curves for different peclet numbers, in the same way that type curves are used to analyze aquifer test data (fig. 26). Effective porosity is estimated using the matchpoints from the type curve and equation 3 :

$$
n_{e}=\frac{t}{\pi h\left(r_{L}^{2}-r_{W}^{2}\right) \cdot t_{d} / Q},
$$

where

$\mathrm{n}_{\mathrm{e}}$ is effective porosity, in percent;

$t$ is the match point time, in days;

$h$ is the injected thickness, in feet;

$r_{L}$ is the radius to the injected well, in feet;

$r_{W}$ is the radius of the withdrawal well, in feet;

$t_{d}$ is the dimensionless match point time; and

$\mathrm{Q}$ is the withdrawal rate, in cubic feet per day.

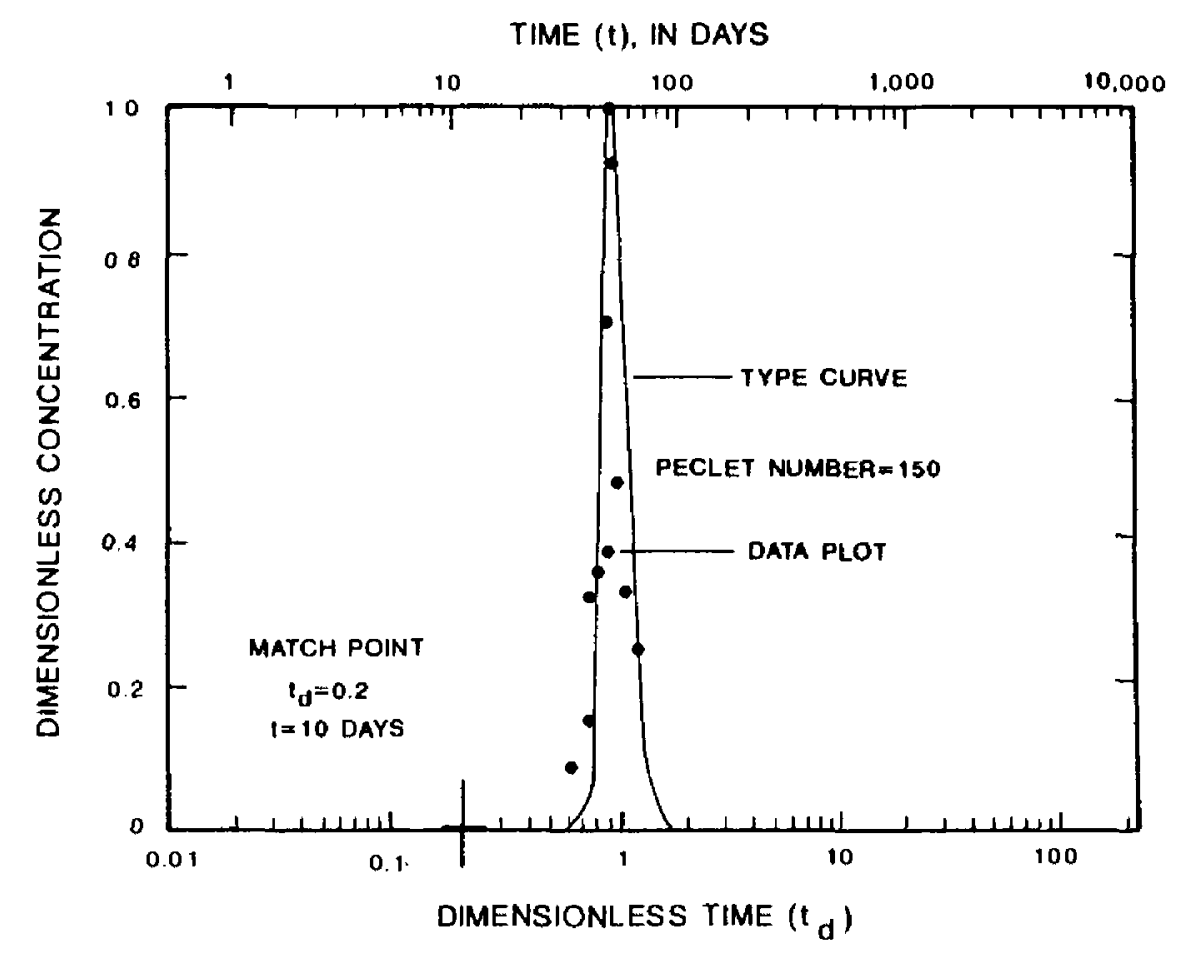

Figure 26. Analysis of the dye-concentration data for well 15 for the test ending November 18, 1990, using the Laplace transform solution for radially convergent flow. 
The longitudinal dispersivity is estimated using equation 4 :

$$
\alpha_{\mathrm{L}}=r_{\mathrm{L}} / P_{\mathrm{e}}
$$

where

$\alpha_{\mathrm{L}}$ is the longitudinal dispersivity, in feet;

$r_{L}$ is the radius to the injection well, in feet; and

$\mathrm{P}_{\mathrm{e}}$ is the Peclet number of the type curve that the field data best fit, dimensionless.

Based on this method, the effective porosity of the aquifer was estimated to be 25 percent when the second dye arrival of the deep tracer test was analyzed, which agrees well with estimates of the effective porosity of the aquifer matrix based on rock-core analysis (21 percent) and observed arrival time (24 percent).

The aquifer dispersivity also was estimated using the Laplace transform solution described by Moench (1989). The flow medium through which each tracer arrival moved was treated separately. Longitudinal dispersivity for the matrix flow tracer arrival was calculated by matching the shape of the tracer timeconcentration curve of the deep injection test to type curves. No estimate was made for the part of the aquifer through which the first dye arrival moved because flow conditions in the secondary porosity might not be Darcian. The longitudinal dispersivity of the aquifer matrix calculated using this method is $1.3 \mathrm{ft}$. This value is representative for diffuse flow through porous media where advection is the dominant mechanism of solute transport.

\section{Tracer-Dilution Method}

Ground-water samples were collected with a thief sampler at specific depths from well 20 during the first 48 hours of the deep tracer test. The rate of decline of tracer concentration in the samples from the injection well was analyzed using a method described by Sun (1976). The horizontal hydraulic conductivity of the aquifer is calculated using the equations

$$
(C-C G) /(C O-C G)=E X P(-A L v t / V)
$$

where

$$
K=v / I \text {, }
$$

$C$ is the tracer concentration at time $t$, in parts per billion;

$\mathrm{CG}$ is the background tracer concentration (equal to 0 for this test);

$\mathrm{CO}$ is the initial tracer concentration, in parts per billion;

$\mathrm{A}$ is twice the borehole diameter for open-hole wells, in feet;

$\mathrm{L}$ is the length of the sampled interval (equal to $1 \mathrm{ft}$ for the thief sampler); $\mathrm{v}$ is the flow velocity in the well, in feet per day;

$t$ is the elapsed time, in days;

$\mathrm{V}$ is the volume of water in the sampled interval (equal to $\left.\pi \mathrm{L}(\mathrm{A} / 4)^{2}\right)$, in cubic feet;

$\mathrm{K}$ is the horizontal hydraulic conductivity of the aquifer matrix, in feet per day; and

I is the ground-water gradient (dimensionless) between the injection well and the pumped well.

The horizontal hydraulic conductivity for $80 \mathrm{ft}$ below land surface is calculated using equations 5 and 6 and the data in table 10 as follows:

$$
\begin{aligned}
(\mathrm{C}-\mathrm{CG}) /(\mathrm{CO}-\mathrm{CG}) & =\operatorname{EXP}(-\mathrm{ALvt} / \mathrm{V}) \\
(90-0) /(160-0) & =\operatorname{EXP}\left[\left(-(1 \mathrm{ft})(1 \mathrm{ft}) \mathrm{v}(0.17 \mathrm{~d}) /\left(\pi \mathrm{L}(\mathrm{A} / 4)^{2}\right]\right.\right. \\
0.56 & =\operatorname{EXP}\left[-\left(0.17 \mathrm{ft}^{2} / \mathrm{d}\right) \mathrm{v} /\left(3.14(1 \mathrm{ft})\left(0.0625 \mathrm{ft}^{2}\right)\right)\right] \\
0.56 & =\operatorname{EXP}\left[-\left(0.17 \mathrm{ft}^{2} / \mathrm{d}\right) \mathrm{v} / 0.20 \mathrm{ft}^{3}\right] \\
1 \mathrm{n}(0.56) & =-0.85 \mathrm{~d} / \mathrm{ft}(\mathrm{v}) \\
-0.58 & =0.85 \mathrm{~d} / \mathrm{ft}(\mathrm{v}) \\
\mathrm{v} & =0.68 \mathrm{ft} / \mathrm{d} . \\
\mathrm{K} & =\mathrm{v} / \mathrm{I} \\
\mathrm{K} & =0.68 / 0.043 \\
\mathrm{~K} & =16 \mathrm{ft} / \mathrm{d} .
\end{aligned}
$$

The hydraulic conductivity was calculated at five depths in the upper $300 \mathrm{ft}$ of the Upper Floridan aquifer (permeable unit one and part of the semiconfining unit) (table 10). The calculated hydraulic conductivities range from 16 to $34 \mathrm{ft} / \mathrm{d}$ and average $26 \mathrm{ft} / \mathrm{d}$. The equivalent range in transmissivity values is from 4,800 to $10,200 \mathrm{ft}^{2} / \mathrm{d}$, and the average is $8,000 \mathrm{ft}^{2} / \mathrm{d}$. These values agree reasonably well with the range of reported values of 7,000 to $14,000 \mathrm{ft}^{2} / \mathrm{d}$ (table 3 ) for the upper $300 \mathrm{ft}$ of the aquifer and with the value estimated from the 50-hour aquifer test and the numerical model $\left(10,500 \mathrm{ft}^{2} / \mathrm{d}\right)$.

The theoretical arrival time of the tracer mass was calculated using the matrix porosity and hydraulic conductivity calculated with the methods described in Freeze and Cherry $(1979$, p. 71$)$ by

$$
\begin{gathered}
V^{\prime}=(K I \times 100) / n_{\mathrm{e}}, \\
t=r / V^{\prime},
\end{gathered}
$$

where

$\mathrm{V}^{\prime}$ is the average linear velocity, in feet per day;

$\mathrm{K}$ is the horizontal hydraulic conductivity, in feet per day;

$\mathrm{I}$ is the ground-water gradient, dimensionless (foot per foot);

$n_{e}$ is the effective porosity of the aquifer matrix, in percent;

$t$ is the arrival time of the tracer mass, in days; and

$r$ is the radial distance from the pumped well to the injection well, in feet. 
Table 10. Horizontal hydraulic conductivity estimates based on tracer dilution in the injection well

[A, twice the bore hole diameter for open hole wells, in feet; $V$, volume of water in the sampled interval (equal to $\pi L(A / 4)^{2}$ ), in cubic feet; $t$, elapsed time, in days;

$C$, tracer concentration at time $t$, in parts per billion; $\mathrm{CO}$, initial tracer concentration, in parts per billion; I, the ground-water gradient, dimensionless, between the injection well and the pumped well; $v$, flow velocity in the well, in feet per day; $\mathrm{K}$, horizontal hydraulic conductivity of aquifer matrix, in feet per day; $-\cdots$, no data]

\begin{tabular}{|c|c|c|c|c|c|c|c|c|}
\hline $\begin{array}{l}\text { Sample depth } \\
\text { (feet) }\end{array}$ & A & $V$ & $t$ & C & $\mathrm{C} / \mathrm{CO}$ & 1 & $\mathbf{v}$ & $\mathbf{K}$ \\
\hline 80 & 1.0 & 0.2 & $\begin{array}{r}-- \\
0.17 \\
.47\end{array}$ & $\begin{array}{r}160 \\
90 \\
16\end{array}$ & $\begin{array}{r}--- \\
0.56 \\
.10\end{array}$ & $\begin{array}{r}--- \\
0.043 \\
.042\end{array}$ & $\begin{array}{r}-- \\
0.68 \\
.71\end{array}$ & $\begin{array}{l}--- \\
16 \\
17\end{array}$ \\
\hline 120 & 1.0 & .2 & $\begin{array}{l}.- \\
.17 \\
.47\end{array}$ & $\begin{array}{r}465 \\
135 \\
13\end{array}$ & $\begin{array}{l}.-- \\
.29 \\
.028\end{array}$ & $\begin{array}{l}. .- \\
.043 \\
.042\end{array}$ & $\begin{array}{l}--- \\
1.46 \\
1.09\end{array}$ & $\begin{array}{l}\overline{34} \\
26\end{array}$ \\
\hline 180 & .84 & .14 & $\begin{array}{l}.- \\
.17 \\
.47\end{array}$ & $\begin{array}{c}370 \\
80 \\
6.9\end{array}$ & $\begin{array}{l}--- \\
.216 \\
.0186\end{array}$ & $\begin{array}{l}-- \\
.043 \\
.042\end{array}$ & $\begin{array}{l}-- \\
1.47 \\
1.01\end{array}$ & $\begin{array}{l}--- \\
34 \\
24\end{array}$ \\
\hline 260 & .76 & .11 & $\begin{array}{l}-.- \\
.17 \\
.46\end{array}$ & $\begin{array}{c}300 \\
80 \\
7.3\end{array}$ & $\begin{array}{l}-.- \\
.266 \\
.024\end{array}$ & $\begin{array}{l}--. \\
.043 \\
.042\end{array}$ & $\begin{array}{l}-- \\
1.16 \\
1.01\end{array}$ & $\begin{array}{l}--- \\
27 \\
24\end{array}$ \\
\hline 290 & .76 & .11 & $\begin{array}{l}-- \\
.42\end{array}$ & $\begin{array}{l}198 \\
7.8\end{array}$ & .0394 & $\begin{array}{l}--- \\
.0417\end{array}$ & 1.12 & --- \\
\hline
\end{tabular}

The calculated theoretical arrival time of the tracer mass is 46 days when using an average hydraulic conductivity of $26 \mathrm{ft} / \mathrm{d}$ and a pumping ground-water gradient (1) of $0.042 \mathrm{ft} / \mathrm{ft}$ between the injection well and the pumped well and assuming a uniform distribution of porosity $\left(n_{e}\right)$ of 25 percent. The close agreement between the estimated and observed tracer arrival times during the deep tracer test indicates that the ratio of hydraulic conductivity to effective porosity is accurate.

The results of tracer tests at the old Tampa well field indicate the heterogeneity of the Upper Floridan aquifer. The multiple dye arrivals indicate groundwater flow through a dual porosity aquifer. Analysis of tracer concentration data representative of groundwater flow through the aquifer matrix indicates an effective porosity of about 25 percent, a longitudinal dispersivity of $1.3 \mathrm{ft}$, and an average hydraulic conductivity of $26 \mathrm{ft} / \mathrm{d}$.

\section{SIMULATION OF TRACER TEST WITH PARTICLE-TRACKING PROGRAM}

The particle-tracking program MODPATH (Pollock, 1989) was used to simulate the ground-water travel times measured during the deep tracer test. The objective of the particle-tracking simulation was to compare ground-water travel times in an equivalent porous media model of the ground-water flow system with observed ground-water travel times. Successful simulation of the assumed matrix flow arrival time of the tracer would support the assumption of equivalent porous media properties for the aquifer matrix. A particle-tracking simulation of the ground-water travel times measured during the deep tracer test was made because the test was performed in that zone of the aquifer most likely to be contaminated and also the zone most likely to be utilized for water supply.

The MODPATH program computes particle locations and travel times in three dimensions based on advective flow in a uniformly porous medium. MODPATH can track particles forward in time and space in the direction of ground-water flow, or backward from model cells toward ground-water recharge locations. Mixiñg of chemical constituents by hydrodynamic dispersion is not considered; therefore, the model cannot be used to predict solute concentrations. However, it can be used to estimate the area of contribution and the time of travel to a well or a well field.

The cell-by-cell flow terms from the steady-state MODFLOW model simulation of the USGS aquifer test were used as input to MODPATH. MODPATH was used to simulate the deep tracer test that used well 20 as the injection well. The Upper Floridan aquifer was modeled using a uniform value of effective porosity for each hydrogeologic unit represented with a model layer. The effective porosity of the aquifer matrix calculated from tracer tests was about 25 percent, but 


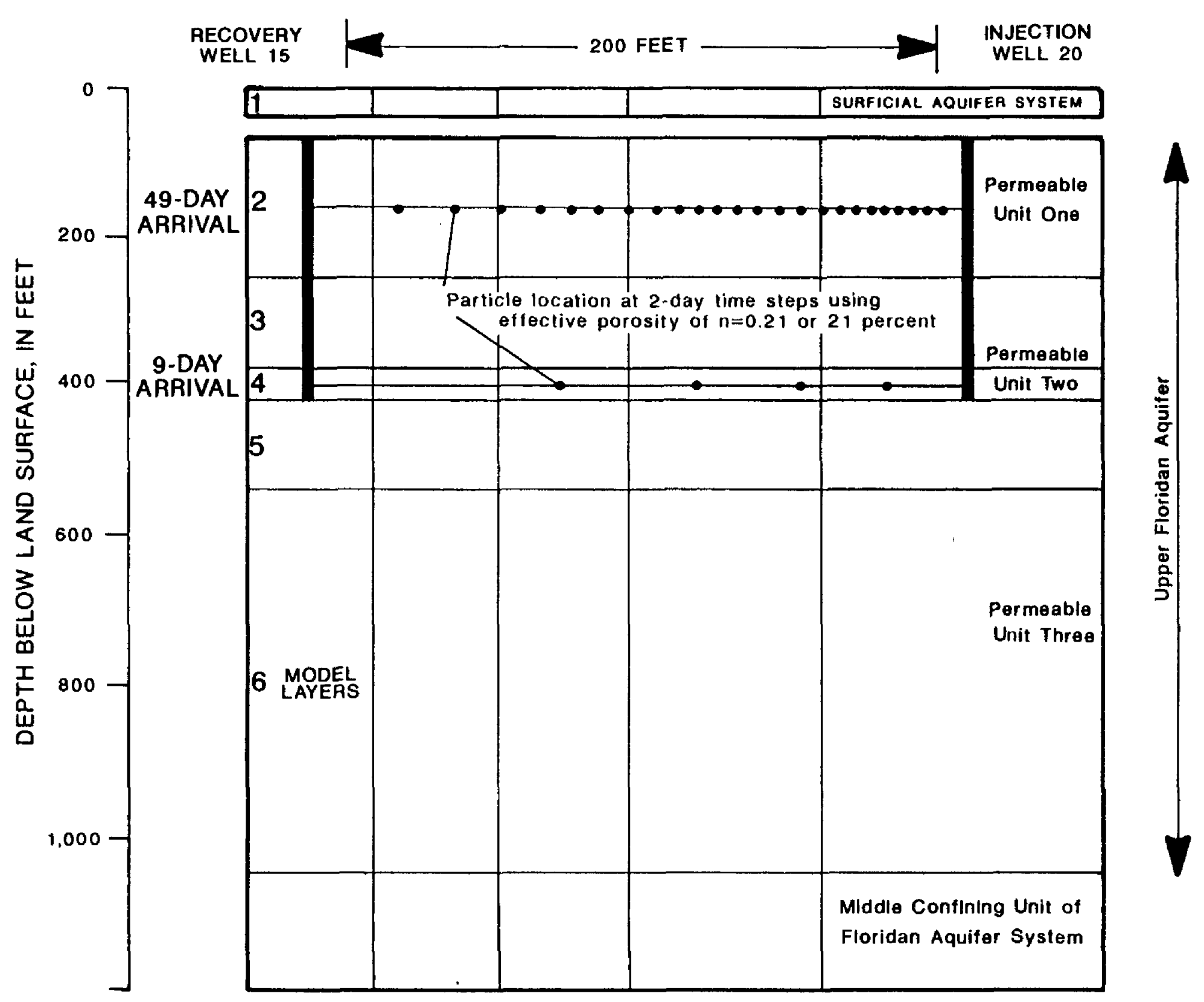

Figure 27. MODPATH particle-tracking simulation of the matrix flow for the dye test ending November 18 , 1990 , assuming a uniform effective porosity of 21 percent for the Upper Floridan aquifer.

this value is probably too high as a result of the discontinuous pumping. An effective porosity of 21 percent, determined from analyses of rock cores, was used for model layers 2 and 4 representing permeable units one and two of the Upper Floridan aquifer, respectively.

Results of simulating the deep tracer test are shown in figure 27. A travel time of 49 days was calculated for layer 2, and 9 days for layer 4 . Ground-water samples collected at $380 \mathrm{ft}$ below land surface from well $11 \mathrm{con}$ tained tracer, indicating that the tracer was present in permeable unit two of the Upper Floridan aquifer. The 8- to 10-day arrival time predicted by MODPATH for model layer 4 was not observed in the dye concentration data collected from well 15 , but that arrival could have been masked by the trailing edge of the preceding dye peak. These results agree well with the observed dye arrival time of 48 days and dye arrival times estimated with analytical equations.
A MODPATH simulation of a hypothetical tracer test was used to estimate the effective porosity value needed to generate a 15-hour travel time from the injection well to the pumped well at the given discharge rate. An effective porosity of 0.3 percent for model layer 2 , and 1.5 percent for model layer 4 was necessary to produce the observed 15-hour time to peak tracer concentration. This test supports the assumption of flow through secondary porosity at the old Tampa well field, because these effective porosity values are about one to two orders of magnitude lower than the range of effective porosity values reported for the matrix of the Upper Floridan aquifer (table 4), and they are equivalent to the effective porosity values calculated using the time to peak tracer concentration for the first tracer arrival and the volumetric displacement method. 


\section{STRATEGIES FOR WELLHEAD PROTECTION}

Previous strategies for wellhead protection were based on the assumption of a uniform distribution of porosity in the Upper Floridan aquifer. Wellhead-protection zones, delineated from contributing areas to wells, were determined in 1988 for 336 wells and 8 well fields permitted for average daily withdrawal rates of 100,000 gal or more per day (Vecchioli and others, 1989) using the existing FDEP guidelines. The vertical travel time from the water table to the top of the Upper Floridan aquifer and the radius of the protection zone were calculated using simple analytical equations. Vecchioli and others (1989), acknowledging the limitations of the assumptions, evaluated the effects of hydrogeologic factors such as the natural slope of the potentiometric surface, hydrologic boundaries, porosity variations, and differences in aquifer thickness on the size and shape of the protection zones delineated by using the FDEP guidelines. The establishment of a hierarchy of wellhead protection on the basis of the calculation of vertical travel time from the water table to the Upper Floridan aquifer, however, does not consider direct connection of the water table to the Upper Floridan aquifer through sinkholes, excavations, and macropores.

The data collected at the old Tampa well field indicate that the assumption of a uniform distribution of effective porosity in the Upper Floridan aquifer is inappropriate. Tracer tests performed at the study site indicate that the Upper Floridan aquifer could be modeled best as a dual porosity, ground-water flow system. Flow takes place through two media: effective secondary porosity and the aquifer matrix. Also, the results of tracer tests indicate that the time required for displacement of water in a specified volume of aquifer, assuming a uniform distribution of effective porosity, is not the minimum travel time between two points within the aquifer. Ground-water travel times for distances of a few hundred feet through the aquifer matrix are on the order of months or years, but travel times in the effective secondary porosity are measured in hours or days. However, the results of borehole video surveys, aquifer tests, and numerical modeling indicate that vertical movement of water across less-permeable units of the Upper Floridan aquifer is primarily through the matrix of the aquifer. For this reason, simulation of groundwater flow through the matrix of the Upper Floridan aquifer need to be considered in the implementation of wellhead-protection strategies.
The objective of wellhead-protection strategies is to limit contributions to the pumped interval from zones that could be contaminated. It is advantageous to conduct borehole tests such as flowmeter logging, video surveys, and geophysical logging to determine the distribution and nature of porosity and permeability in the aquifer. The first permeable unit below the intermediate confining unit of the Upper Floridan aquifer is the most likely to be contaminated, and pumping from that unit could induce leakage from the surficial aquifer system. Alternative well-field designs that incorporate more production wells, deeper casings, and moderate pumping rates should reduce leakage from the overlying sediments in the immediate vicinity of the pumped well(s).

Computer simulation of the effects of different stresses on the ground-water flow system provides standards for comparison that can be used to develop wellhead-protection strategies. The wellhead-protection strategy presented here is based on limiting the use of shallow permeable units of the Upper Floridan aquifer because those units could have well developed zones of effective secondary porosity and are the most vulnerable to contamination. Withdrawal of water from shallow permeable units of the Upper Floridan aquifer also can induce leakage from the surficial aquifer system, thereby increasing the potential for contamination. For this study, the effectiveness of four wellheadprotection strategies was evaluated using the calibrated, steady-state, MODFLOW model and MODPATH.

\section{Alternative Well Construction}

Two particle-tracking simulations were run to demonstrate how the area of contribution to a pumped well might change when the well casing is deepened. The simulation of aquifer response to a production well having $50 \mathrm{ft}$ of casing and open to the upper $375 \mathrm{ft}$ of the Upper Floridan aquifer (permeable units one and two and the intervening semiconfining unit, model layers 2 , 3 , and 4) is used as a standard for comparison (fig. 28). This is compared to the simulated response to a pumped well with $380 \mathrm{ft}$ of casing (fig. 29) open to the lower 770 $\mathrm{ft}$ of the Upper Floridan aquifer (permeable units two and three and the intervening semiconfining unit, model layers 4,5 , and 6). The pumping rate is $1 \mathrm{Mgal} / \mathrm{d}$ for each test. A MODPATH particle-tracking analysis was performed for each simulation by backtracking 100 to 400 particles from the uppermost model layer stressed by the pumped well toward the recharge locations. 
The area encompassed by the 10-year time of travel in model layer 2 to the single well was $0.18-\mathrm{mi}^{2}$. Forty-five percent of the total pumpage was derived from model layer 2 (fig. 28). The area of contribution encompassed by the 30 -year time of travel in model layer 2 to the single well includes the model boundaries and may not be accurate. Therefore, the $0.18-\mathrm{mi}^{2}$ area encompassed by the 10-year time of travel in model layer 2 was used as the standard for comparison.

The area of contribution from layer 2 encompassed by the 10-year time of travel was zero for the second simulation. The area of contribution from layer 2 encompassed by the 30 -year time of travel was $0.08 \mathrm{mi}^{2}$

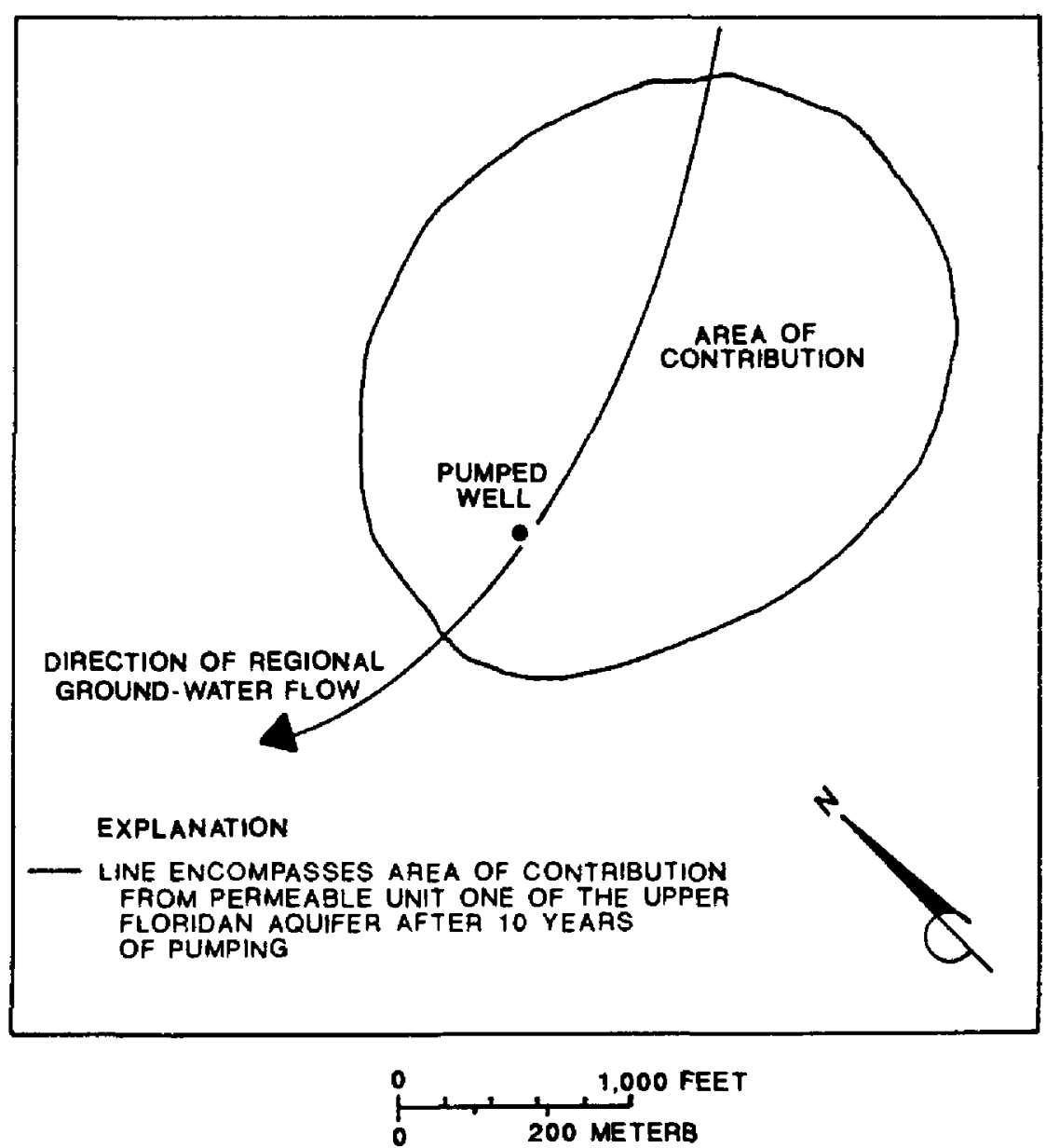

$$
\begin{aligned}
& \text { CONDITIONS SIMULATED } \\
& \text { Pumping rate - } 1 \text { million gallons per day } \\
& \text { Pumped interval - model layers 2, 3, 4; permeable units } \\
& \text { one and two; and intervening } \\
& \text { semiconfining unit } \\
& \text { Well depth - } 425 \text { feet } \\
& \text { Casing depth - } 50 \text { feet } \\
& \text { Depth to top of permeable unit one - } 50 \text { feet } \\
& \text { Depth to bottom of permeable - } 250 \text { feet } \\
& \text { unit one } \\
& \text { Production rate from permeable - 450,000 gallons per day } \\
& \text { unit two } \\
& \text { Number of particles - } 100 \text { placed in permeable unit one } \\
& \text { Area of contribution from permeable - } 0.18 \text { square mile } \\
& \text { unit one of Upper Floridan aquifer }
\end{aligned}
$$

Figure 28. Simulated area of contribution encompassed by the 10-year time of travel from permeable unit one to a well completed in permeable units one and two of the Upper Floridan aquifer. in the second simulation and supplied 6 percent of the pumpage (fig. 29). Thus, deepening the well casing so that the well withdrew water directly from permeable units two and three approximately halved the area of contribution from the layer most likely to be contaminated and increased the time of travel to the well.

\section{Alternative Well-Field Design}

A particle-tracking analysis also was made to compare the area of contribution for a single deep well with $380 \mathrm{ft}$ of casing pumped at a rate of $1 \mathrm{Mgal} / \mathrm{d}$ (fig. 29) to that of two wells with $380 \mathrm{ft}$ of casing pumped at a rate

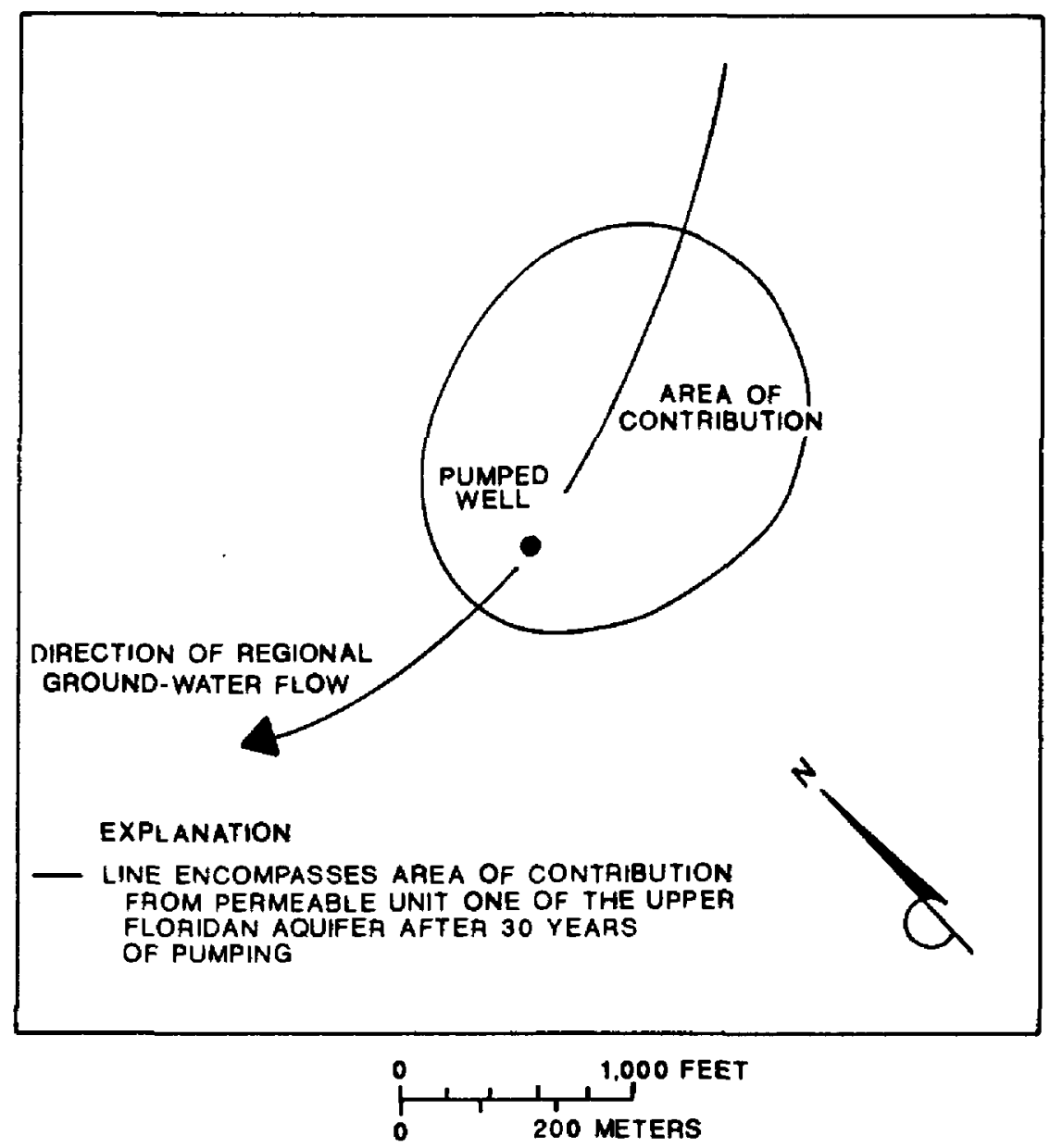

$$
\begin{aligned}
& \text { CONDITIONS SIMULATED } \\
& \text { Pumping rate - } 1 \text { million gallons per day } \\
& \text { Pumped interval - model layers 4, 5, 6; permeable units } \\
& \text { two and three; and intervening } \\
& \text { semiconfining unit } \\
& \text { Well depth }-1,100 \text { feet } \\
& \text { Casing depth - } 380 \text { feet } \\
& \text { Depth to top of permeable unit one - } 50 \text { feet } \\
& \text { Depth to bottom of permeable - } 250 \text { feet } \\
& \text { unit one } \\
& \text { Production rate from permeable - } 60,000 \text { gallons per day } \\
& \text { unit two } \\
& \text { Number of particles - } 400 \text { placed in permeable unit one } \\
& \text { Area of contribution from permeable }-0.08 \text { square mile } \\
& \text { unit one of Upper Floridan aquifer }
\end{aligned}
$$

Figure 29. Simulated area of contribution encompassed by the 30-year time of travel from permeable unit one to a well completed in permeable units two and three of the Upper Floridan aquifer. 
of $0.50 \mathrm{Mgal} / \mathrm{d}$ each (fig. 30 ). All wells withdrew water from model layers 4,5 , and 6 , simulating permeable units two and three and the intervening semiconfining unit of the Upper Floridan aquifer. The analysis was performed by seeding 400 particles in layer 4 at each well and backtracking them toward the recharge locations.

The areas of contribution from model layer 2 were delineated for two production wells aligned parallel to the regional ground-water flow. The area encompassed by the 30-year travel time to the wells from model layer 2 was $0.097 \mathrm{mi}^{2}$ (fig. 30), which is slightly larger than the $0.08-\mathrm{mi}^{2}$ area encompassed by the 30 -year travel
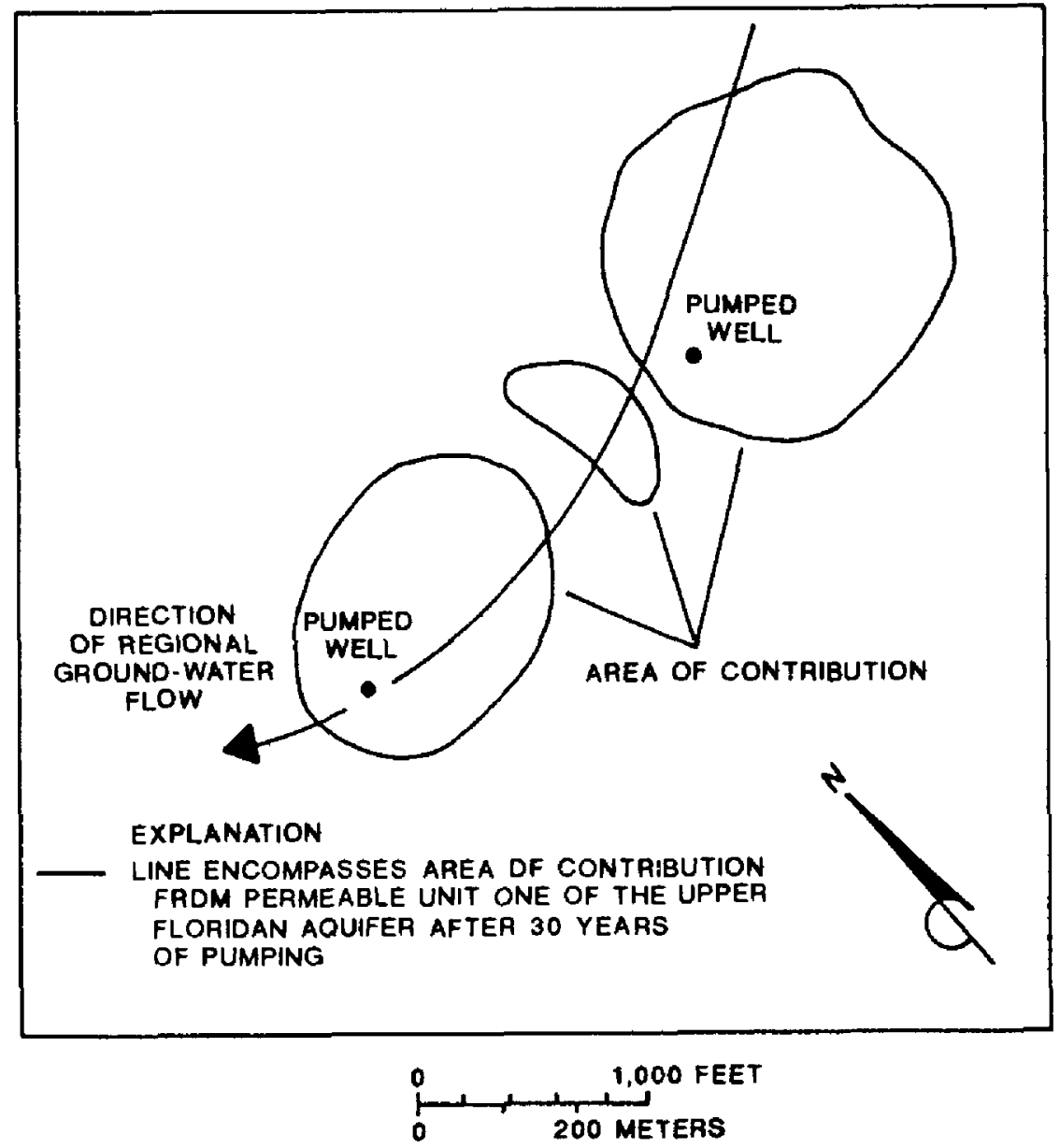

\section{CONDITIONS SIMULATED}

Pumping rate - 1 million gallons per day Pumped interval - model layers 4, 5, 6; permeable units two and three; and intervening semiconfining unit

Well depth $-1,100$ feet

Casing depth - 380 feet

Depth to top of permeable unit one - 50 feet

Depth to bottom of permeable - 250 feet unit one

Production rate from permeable - 60,000 gallons per day unit two

Number of particles - 400 placed in permeable unit one Area of contribution from permeable - 0.097 square mile unit one of Upper Floridan aquifer

Figure 30. Simulated area of contribution encompassed by the 30-year time of travel from permeable unit one to two wells completed in permeable units two and three of the Upper Floridan aquifer and aligned parallel to the regional groundwater flow. time to a single well (fig. 29). This area supplied 10 percent of the total pumpage. The orientation of wells parallel to the regional ground-water gradient causes the cones of depression of the individual wells to overlap one another. The overlap induces greater leakage from overlying layers, which produces an additional area of contribution from model layer 2 between the two pumped wells (fig. 30).

A similar analysis was made to show the areas of contribution from model layer 2 to two wells pumped at a rate of $0.5 \mathrm{Mgal} / \mathrm{d}$ each when the wells are aligned perpendicular to the regional ground-water flow (fig. 31).

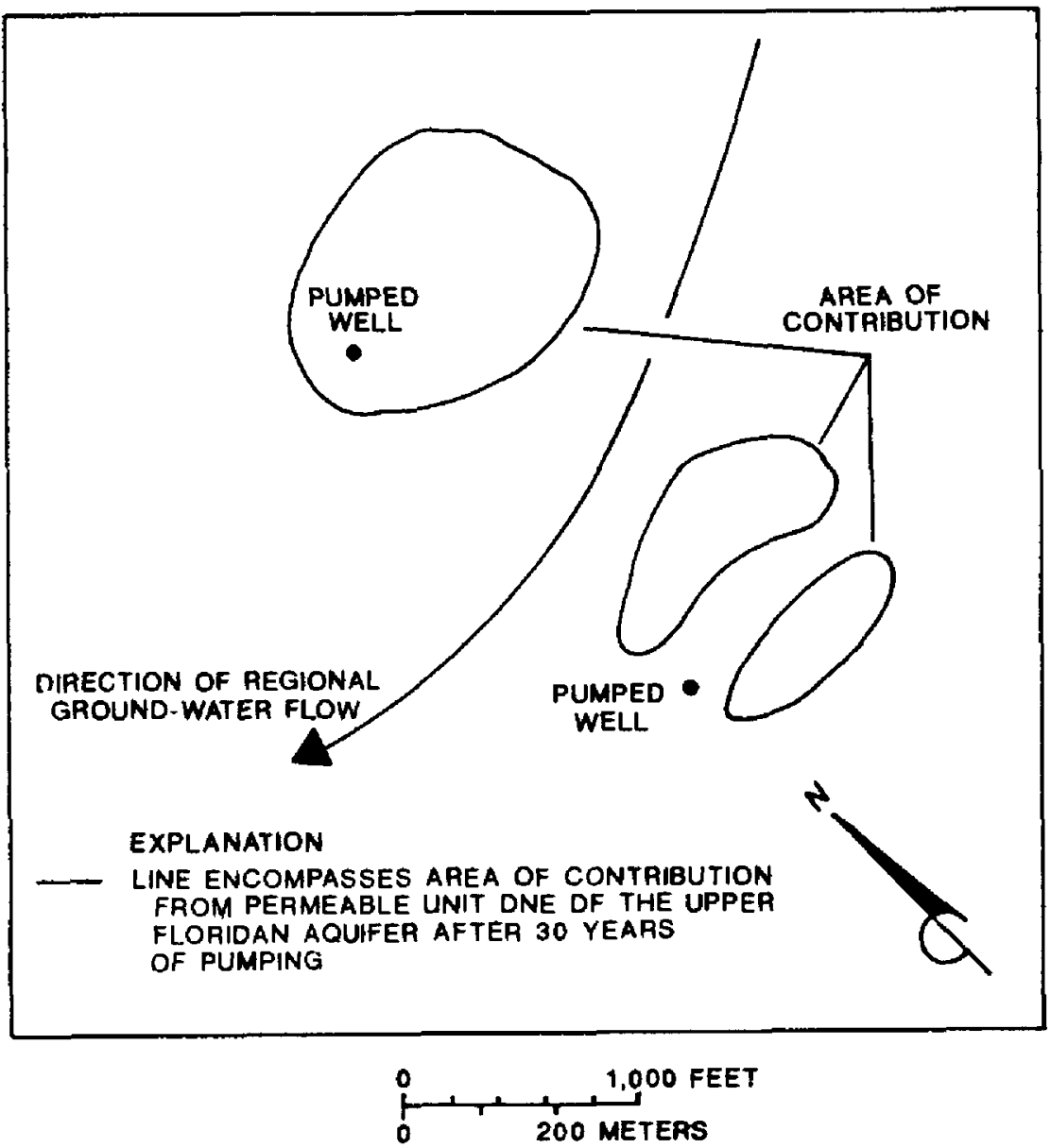

\section{CONDITIONS SIMULATED}

Pumping rate - 0.5 million gallons per day Pumped interval - model layers 4, 5, 6; permeable units two and three; and intervening semiconfining unit

Well depth $-1,100$ feet

Casing depth - 380 feet

Depth to top of permeable unit one - 50 feet

Depth to bottom of permeable - 250 feet unit one

Production rate from permeable - 60,000 gallons per day unit two

Number of particles - 400 placed in permeable unit one Area of contribution from permeable - 0.06 square mile unit one of Upper Floridan aquifer

Figure 31. Simulated area of contribution encompassed by the 30-year time of travel from permeable unit one to two wells completed in permeable units two and three of the Upper Floridan aquifer and aligned perpenticular to the regional ground-water flow. 
Table 11. Areas of contribution simulated for four wellheadprotection strategies

[Mgal/d, million gallons per day; $\mathrm{ft}$, feet; $\mathrm{mi}^{2}$, square miles]

\begin{tabular}{cccccc}
\hline $\begin{array}{c}\text { Number } \\
\text { of } \\
\text { pumping } \\
\text { wells }\end{array}$ & $\begin{array}{c}\text { Well } \\
\text { discharge } \\
\text { rate } \\
\text { (Mgal/d) }\end{array}$ & $\begin{array}{c}\text { Pumped } \\
\text { interval } \\
\text { (ft) }\end{array}$ & $\begin{array}{c}\text { Time } \\
\text { (years) }\end{array}$ & $\begin{array}{c}\text { Total area of } \\
\text { contribution } \\
\text { from layer 2 } \\
\left(\mathbf{m i}^{2}\right)\end{array}$ & $\begin{array}{c}\text { Percent } \\
\text { of } \\
\text { pumpage } \\
\text { derived } \\
\text { from } \\
\text { layer 2 }\end{array}$ \\
\hline 1 & 1.0 & $50-425$ & 10 & 0.18 & 45 \\
1 & 1.0 & $380-800$ & 30 & .08 & 6 \\
2 & .5 & $380-800$ & 30 & .097 & 10 \\
2 & .5 & $380-800$ & 30 & .06 & 6 \\
\hline
\end{tabular}

The total area of contribution to the wells from layer 2 , encompassed by the 30-year time of travel to the wells from layer 2, was $0.06 \mathrm{mi}^{2}$ and supplied 6 percent of the total pumpage. This area was the smallest calculated by the four computer simulations.

The results of the particle-tracking simulations indicate that deepened well casings and decentralized withdrawal decreased the leakage and total area of contribution from the overlying layers to the pumped interval, thus reducing the potential for contamination of wells. The use of multiple wells as a protection strategy is most effective when wells are oriented perpendicular to the ground-water flow, thereby reducing the potential for overlapping cones of depression. The wellheadprotection strategies reduced the area of contribution from layer 2 by 47 to 67 percent, and the contribution from layer 2 decreased by 78 to 87 percent (table 11 ). Simultaneously, the time related area of contribution from the aquifer matrix to the well was increased 200 percent, theoretically increasing the response time to a contaminant spill. The conclusions drawn from the particle-tracking simulations can be applied to any vertically layered aquifer system.

\section{SUMMARY AND CONCLUSIONS}

The Upper Floridan aquifer is the primary source of water supply for west-central Florida. The aquifer is at risk over much of the area from sources of contamination at land surface. An evaluation of wellheadprotection strategies for the Upper Floridan aquifer was made using the 40-acre old Tampa well field in northeastern Hillsborough County as a test site.
Three hydrogeologic units were identified in the ground-water flow system at the old Tampa well field: the surficial aquifer system, the intermediate confining unit, and the Floridan aquifer system. The surficial aquifer system and the intermediate confining unit overlie and collectively confine the Floridan aquifer system.

The top of the Floridan aquifer system at the study site was penetrated by wells at different depths. The results of test drilling and surface geophysical surveys support the interpretation of the top of the aquifer as a paleokarst surface. The Floridan aquifer system is divided into an upper and lower aquifer by a middle confining unit of lower permeability. The Upper Floridan aquifer at the old Tampa well field can be further subdivided into at least three permeable units separated by semiconfining units of lower permeability. Zones of effective secondary porosity are layered throughout the upper $400 \mathrm{ft}$ of the aquifer. Rock cores from the Upper Floridan aquifer at the site have effective porosity values of 21 to 46 percent.

The results of an aquifer test in July 1990 indicate that the Upper Floridan aquifer at the well field responds to long-term pumping as an equivalent porous medium. The transmissivity of the upper $400 \mathrm{ft}$ of the Upper Floridan aquifer was calculated to be about $23,000 \mathrm{ft}^{2} / \mathrm{d}$. The transmissivity estimate is representative of the cumulative transmissivity of two permeable units within the aquifer and an intervening semiconfining unit. The transmissivity of the individual units was estimated by dividing the total transmissivity proportionally among the units based on pumping flowmeter logs. The estimated transmissivities are $10,350 \mathrm{ft}^{2} / \mathrm{d}$ for permeable unit one, $1,150 \mathrm{ft}^{2} / \mathrm{d}$ for the semiconfining unit, and $11,500 \mathrm{ft}^{2} / \mathrm{d}$ for permeable unit two. It is difficult to use analytical models to estimate the hydraulic coefficients of the Upper Floridan aquifer because the ground-water flow system is complex.

Uniform porosity numerical models were used to simulate flow in the Upper Floridan aquifer at the old Tampa well field. The results of the aquifer test of July 1990 were used to calibrate a numerical aquifer simulation model of the ground-water flow system at the site. The model calibration was tested by simulating the results of an aquifer test conducted in December 1990. Results of numerical modeling indicate that the transmissivity of the upper $400 \mathrm{ft}$ of the Upper Floridan aquifer at the site is about $20,000 \mathrm{ft}^{2} / \mathrm{d}$ and the storage coefficient is about $10^{-4}$. 
Ground-water tracer tests were performed in the upper $300 \mathrm{ft}$ of the Upper Floridan aquifer by injecting a tracer into the open-hole interval of a well completed in the aquifer. Movement of tracer was induced by pumping a well $200 \mathrm{ft}$ from the injection well and open to the same depth interval. Multiple tracer arrivals at the pumped well are interpreted as ground-water flow in two media: (1) interconnected secondary porosity where conduit flow occurs, and (2) the aquifer matrix where diffuse flow occurs. Tracer arrival times on the order of hours for the $200-\mathrm{ft}$ horizontal distance between the injection and pumped wells are interpreted as ground-water movement through interconnected secondary porosity. A tracer arrival after 36 days of pumping, with a peak concentration after 48 days of pumping, closely approximates the theoretical tracer arrival time calculated using uniform porosity assumptions and volumetric displacement. This was interpreted as the matrix flow arrival.

The effective porosity and longitudinal dispersivity of the aquifer matrix, based on the tracer test data, were estimated to be 25 percent and $1.3 \mathrm{ft}$, respectively. Calculated horizontal hydraulic conductivity values of the upper $300 \mathrm{ft}$ of the Upper Floridan aquifer, based on dilution of the tracer in the injection well, ranged from 16 to $34 \mathrm{ft} / \mathrm{d}$, equivalent to a transmissivity of about 4,800 to $10,200 \mathrm{ft}^{2} / \mathrm{d}$. The estimated transmissivity of that part of the Upper Floridan aquifer is approximately $10,500 \mathrm{ft}^{2} / \mathrm{d}$, based on aquifer tests.

The use of uniform porosity and permeability models to predict ground-water travel time between two points in the aquifer is inappropriate because of ground-water flow through effective secondary porosity. The distribution and degree of connection of the secondary porosity determines the minimum travel time between two points within the aquifer. Because the aquifer responds to long-term pumping as an equivalent porous medium, ground-water travel times in the aquifer matrix can be estimated with uniform porosity models. Ground-water travel times through the aquifer matrix are on the order of months or years, but travel times in the interconnected secondary porosity are measured in hours or weeks. The results of borehole video surveys, aquifer tests, and numerical modeling indicate that vertical movement of water across lesspermeable units of the Upper Floridan aquifer is primarily through the matrix of the aquifer. Thus, consideration of ground-water flow through the matrix of the Upper Floridan aquifer is relevant to the evaluation of wellhead-protection strategies for west-central Florida.
The wellhead-protection strategy presented in this study is based on limiting the use of shallow permeable units of the Upper Floridan aquifer. The uppermost permeable unit of the Upper Floridan aquifer has effective secondary porosity and is the unit most vulnerable to a contaminate spill at the surface. Withdrawal of water from this unit induces leakage from the surficial aquifer system and increases the possibility of contamination.

The calibrated steady-state numerical model and a particle-tracking program were used to simulate ground-water flow in the aquifer matrix. The particletracking model calculated ground-water travel times of 48 to 50 days between the injection well and the pumped well when using an effective porosity of 21 percent. These results closely approximate the observed time to peak tracer concentration measured during the deep tracer test. The particle-tracking model was then used to estimate the time of travel and areas of contribution to hypothetical wells to evaluate wellhead-protection strategies.

Wellhead-protection strategies were judged to be effective if they reduced the withdrawal of water from the upper permeable unit of the Upper Floridan aquifer. Results of particle-tracking analyses indicate that, by limiting the withdrawal of water to the second permeable unit and by allowing only moderate pumping rates, the leakage and total area of contribution from the overlying layers would be reduced. The orientation of multiple wells to the local ground-water gradient is an important consideration for wellhead-protection strategies. Locating wells in a line perpendicular to the local ground-water gradient reduces the potential for overlapping cones of depression. Overlapping cones of depression increase leakage from overlying layers, potentially increasing the risk of contamination.

Protective strategies that limit recharge to the pumped interval from the overlying sediments would provide the most protection for pumped wells. The upper permeable unit of the Upper Floridan aquifer is the unit most likely to be contaminated by direct recharge through sinkholes or excavations. Pumping from that unit also may induce leakage from the surficial aquifer system. Alternative well-field designs that incorporate more production wells, deeper casings, and moderate pumping rates reduce the risk of contamination of public-supply wells from nearby surface sources. 


\section{REFERENCES CITED}

Andrews, W.J., 1990, Transmissivity and well yields of the Upper Floridan aquifer in Florida: Florida Geological Survey Map Series 132, 1 sheet.

Applin, P.L., 1951, Preliminary report on buried pre-Mesozoic rocks in Florida and adjacent states: U.S. Geological Survey Circular 91, $28 \mathrm{p}$.

Bair, E.S., Springer, A.E., and Roadcap, G.S., 1991, Delineation of traveltime-related capture areas of wells using analytical flow models and particle tracking analysis: Ground Water, v. 29, no. 3, p. 387-397.

Barr, G.L., 1989, Potentiometric surface of the Upper Floridan aquifer, west-central Florida, September 1988: U.S. Geological Survey Open-File Report 88-730, 1 sheet.

Bengtsson, T.O., Downing, H.C., and Geurink, J.S., 1986, The hydrologic effects from intense groundwater pumpage in east-central Hillsborough County: Southwest Florida Water Management District, 11 p.

Buxton, H.T., Reilly, T.E., and Smolensky, D.A., 1991, Particle tracking analysis of recharge areas on Long Island, New York: Ground Water, v. 29, no. 1, p. 63-71.

$\mathrm{CH}_{2} \mathrm{M}$ Hill, Inc., 1990, Drilling and testing of wells 2-D, 3-D, and 4-D, Northwest Hillsborough Water Resources Project: Consultant's report prepared for the Southwest Florida Water Management District Project No. P00610, app. F, Rock Core Analysis.

Culbreth, M.A., 1988, Geophysical investigation of lineaments in South Florida: Masters Thesis, Department of Geology, University of South Florida, 97 p.

Florida Department of Environmental Regulation, 1987, Water quality standards: Chapter 17.3, in Florida Administrative Code.

Freeze, R.A., and Cherry, J.A., 1979, Groundwater: Englewood Cliffs, N.J., Prentice-Hall, 604 p.

Gilboy, A.E., 1985, Hydrogeology of the Southwest Florida Water Management District: Southwest Florida Water Management District Technical Report 85-01, 18 p.

Gordon, M.J., 1986, Dependence of effective porosity on fracture continuity in fractured media: Ground Water, v. 24 , no. 4 , p. $446-452$.

Hickey, J.J., 1977, Hydrogeologic data for the McKay Creek subsurface waste-injection test site, Pinellas County, Florida: U.S. Geological Survey Open-File Report 77-802, $94 \mathrm{p}$.

---- 1979, Hydrogeologic data for the South Cross Bayou subsurface-injection test site, Pinellas County, Florida: U.S. Geological Survey Open-File Report 78-575, 87 p.

---- 1984, Field testing the hypothesis of darcian flow through a carbonate aquifer: Ground Water, v. 22, no. 5, p. 544-547.

Jones, K.C., 1985, Aquifer characteristics within the Southwest Florida Water Management District: Southwest Florida Water Management District.
Knochenmus, L.A., and Barr, G.L., 1990, Potentiometric surface of the Upper Floridan aquifer, west-central Florida, September 1989: U.S. Geological Survey Open-File Report 90-133, 1 sheet.

Lewelling, B.R., 1989, Potentiometric surface of the Upper Floridan aquifer, west-central Florida, May 1988: U.S. Geological Survey Open-File Report 88-461, 1 sheet.

Lohman, S.W., 1979, Ground-water hydraulics: U.S. Geological Survey Professional Paper 708, $70 \mathrm{p}$.

McDonald, M.G., and Harbaugh, A.W., 1988, A modular three-dimensional finite-difference ground-water flow model: U.S. Geological Survey Techniques of WaterResources Investigations, book 6, chap. A1, $576 \mathrm{p}$.

Menke, C.G., Meredith, E.W., and Wetterhall, W.S., 1961, Water resources of Hillsborough County, Florida: Florida Geological Survey Report of Investigations no. 25, $101 \mathrm{p}$.

Miller, J.A., 1986, Hydrogeologic framework of the Floridan aquifer system in Florida and in parts of Georgia, Alabama, and South Carolina: U.S. Geological Survey Professional Paper 1403-B, 91 p.

Moench, A.F., 1989, Convergent radial dispersion: A Laplace transform solution for aquifer tracer testing: Water Resources Research, v. 25, no. 3, p. 439-447.

Mull, D.S., Smoot, J.L., and Libermann, T.D., 1988, Dye tracing techniques used to determine ground-water flow in a carbonate aquifer system near Elizabethtown, Kentucky: U.S. Geological Survey Water-Resources Investigations Report 87-4147, 95 p.

Pollock, D.W., 1989, Documentation of computer programs to compute and display pathlines using results from the U.S. Geological Survey modular three-dimensional finite-difference ground-water flow model: U.S. Geological Survey Open-File Report 89-381, 188 p.

Reeder, H.O., Wood, W.W., Ehrlich, G.G., and Sun, R.J., 1976, Artificial recharge through a well in fissured carbonate rock, West St. Paul, Minnesota: U.S. Geological Survey Water-Supply Paper 2004, 80 p.

Ryder, P.D., Johnson, D.M., and Gerhart, J.M., 1980, Model evaluation of the hydrogeology of the Morris Bridge well field and vicinity in west-central Florida: U.S. Geological Survey Water-Resources Investigations 80-29, 92 p.

Sabatini, D.A., and Austin, T.A., 1991, Characteristics of Rhodamine WT and Fluorescein as adsorbing groundwater tracers: Ground Water, v. 29, no. 3, p. 341-349.

Safko, P.G., and Hickey, J.J., 1992, A preliminary approach to the use of borehole television surveys for characterizing secondary porosity in the Floridan aquifer system: U.S. Geological Survey Water-Resources Investigations Report 91-4168.

Schreuder and Davis, 1nc., 1991, Pemberton Creek site well construction and aquifer testing: Consultant's report prepared for and in the files of the West Coast Regional Water Supply Authority, $63 \mathrm{p}$. 
Scott, T.M., 1988, The lithostratigraphy of the Hawthorn Group (Miocene) of Florida: Florida Geological Survey Bulletin no. 59, 148 p.

Sinclair, W.C., 1973, Hydrogeologic characteristics of the surficial aquifer in northwest Hillsborough County, Florida: U.S. Geological Survey Open File Report 73-023, $97 \mathrm{p}$.

---- 1982, Sinkhole development resulting from ground water withdrawal in the Tampa area, Florida: U.S. Geological Survey Water-Resources Investigations 81-50, $19 \mathrm{p}$.

Smith, E.D., and Vaughan, N.D., 1985, Aquifer test analysis in nonradial flow regimes: A case study: Ground Water, v. 23 , no. 2 , p. $167-175$.

Southeastern Geological Society, 1986, Hydrogeological units of Florida: Florida Geological Survey Special Publication no. 28, 9 p.

Southwest Florida Water Management District, 1988, Ground-water resource availability inventory, Hillsborough County, Florida: Southwest Florida Water Management District Resource Management and Planning Departments, $203 \mathrm{p}$.

Stewart, H.G., 1966, Ground-water resources of Polk County, Florida: Florida Geological Survey Report of Investigations no. 44, $170 \mathrm{p}$.
Sun, R.J., 1976, Hydrodynamic dispersion and movement of injected water, p. 52-75, in Reeder, H.O., Wood, W.W., Ehrlich, G.G., and Sun, R.J., Artificial recharge through a well in fissured carbonate rock, West St. Paul, Minnesota: U.S. Geological Survey WaterSupply Paper 2004, 80 p.

Swancar, Amy, and Hutchinson, C.B., 1992, Chemical and isotopic composition and potential for contamination of water in the Upper Floridan aquifer, west-central Florida, 1986-89: U.S. Geological Survey Open-File Report 92-47, $47 \mathrm{p}$.

Vecchioli, John, Hunn, J.D., and Aucott, W.R., 1989, Evaluation of methodology for delineation of protection zones around public-supply wells in west-central Florida: U.S. Geological Survey Water-Resources Investigations Report 88-4051, $36 \mathrm{p}$.

Vernon, R.O., 1951, Geology of Citrus and Levy Counties, Florida: Florida Geological Survey Bulletin no. 33, $256 \mathrm{p}$.

Wolansky, R.M., and Corral, M.A., 1985, Aquifer tests in west-central Florida, 1952-76: U.S. Geological Survey Water-Resources Investigations Report 84-4044, 127 p. 


\section{APPENDIX}

\section{Apparent Secondary Porosity Logs from Borehole Video Survey}

Borehole television logs of wells at the old Tampa well field were viewed to compile logs of apparent secondary porosity. The apparent secondary porosity log is divided into two sections: (1) description of notable discontinuous features in the borehole wall and (2) description of the continuous borehole wall characteristics. The terminology used to describe the secondary porosity in the boreholes is that of Safko and Hickey (1992) and is summarized below.

Vug porosity appears as a void space in the rock, visible on only part of the borehole. Cavern porosity appears as a void space in the rock where the entire borehole wall disappears from view. Fracture porosity appears as cracks or breaks in the rock. The size of a vug porosity feature has been standardized to the grain-size classification of pebble (0.01-0.21 ft), small cobble (0.21-0.42 ft), and large cobble (0.42-0.84 ft) according to J.J. Hickey (U.S. Geological Survey, oral commun., 1991). The size of cavern porosity is standardized to small $(0.84-2.00 \mathrm{ft})$ and large $(>2.00 \mathrm{ft})$. Fracture porosity was not classified as to size. The descriptions of the character of the borehole walls use common adjectives that refer to the degree of uniformity of the hole. Smooth, rough, uneven, irregular, blocky, pitted, grainy, and round are used with the normal meaning. Descriptions of the character of the borehole wall take the following general form: shape of borehole, relative smoothness of wall surface, general appearance of density of rock, and visual estimate of the relative porosity of the matrix based on the previous characteristics.

Because the visible secondary porosity could have been created during drilling, it is termed "apparent secondary porosity." Apparent secondary porosity is termed effective secondary porosity if water enters the well bore from that feature. The identification of effective secondary porosity requires the use of flowmeter, fluid resistivity, and temperature logs and the driller's log containing comments on bit drops, dredging zones, and lost circulation. This exercise was performed for those wells for which the necessary data were collected, including wells $15,15 \mathrm{~A}$, and the Ocala monitor well, and is summarized in the main body of the report as figure 10. Detailed descriptions of the "apparent secondary porosity" observed in wells at the old Tampa well freld are presented here. 


\section{Well 11}

Well 11 was drilled using a cable-tool drill rig. Much of the borehole has an oblong shape and clearly shows groves worn in the side of the borehole by the up and down motion of the drill stem. Well 11 was logged while pumping well 15, located $25 \mathrm{ft}$ due west of well 11 , at a rate of $980 \mathrm{gal} / \mathrm{min}$.

\section{Notable discontinuous features}

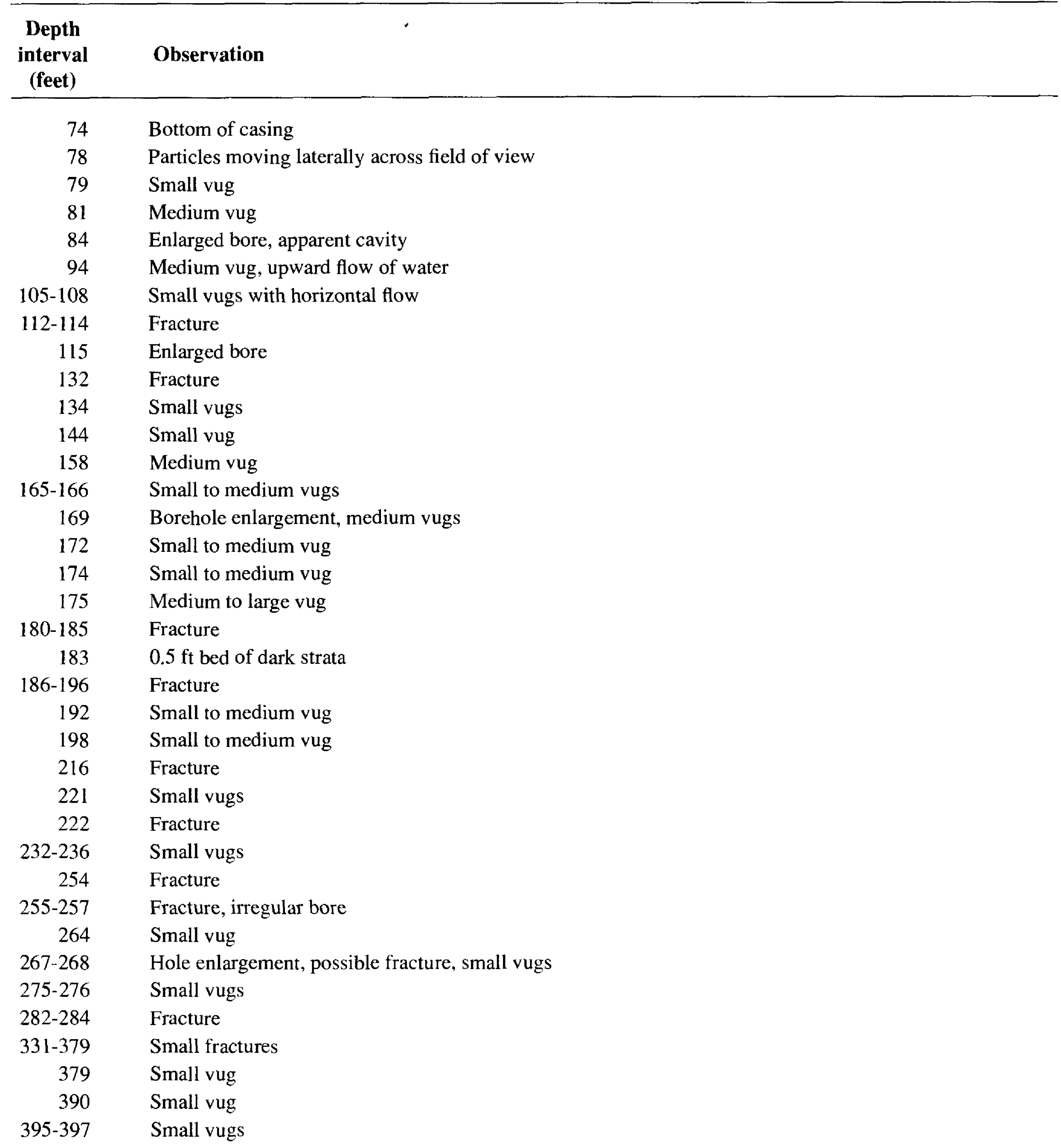




\begin{aligned} $\begin{array}{r}\text { Depth } \\ \text { interval } \\ \text { (feet) }\end{array} &$ Observation \\ \hline 400 & Short elongated vug \\ $403-409 &$ Fractures \\ 444 & Fracture \\ $444-448 &$ Small vugs \\ $496-497 &$ Fracture, nodules of dark rock \\ $505-522 &$ Fracture \\ 527 & Small to medium vugs \\ $528-534 &$ Fractures \\ 544 & Small cavity \\ 586 & Small vugs \\ 591 & Small vug \\ 592 & Fracture \\ 595 & Medium vug \\ 599 & Large vug \\ 615 & Medium vugs \\ 618 & Small cavity \\ 618 & Small vugs, short fracture \\ $622-624 &$ Fracture \\ $626-633 &$ Fractures \\ $638-641 &$ Medium to large vugs \\ 641 & Intersecting, high angle fractures (X) \\ 641 & At this depth, the camera operator decided to discontinue logging because of borehole conditions. \end{aligned}

\section{Summary of Borehole Wall Characteristics}

\section{Notable continuous features}

\begin{aligned} \multicolumn{1}{r}{$\begin{array}{c}\text { Depth } \\ \text { interval } \\ \text { (feet) }\end{array}$} & Observation \\ \hline 74 & Bottom of casing \\ $74-82 &$ Rounded to irregular, pitted, porous \\ $82-105 &$ Rounded, smooth, numerous very small vugs, low matrix porosity \\ $105-119 &$ Irregular to oblong, blocky, smooth, dense, low matrix porosity \\ $119-125 &$ Oblong, pitted to slightly pitted, porous \\ $125-144 &$ Oblong, smooth to slightly pitted, low matrix porosity \\ $144-161 &$ Oblong, pitted, grainy, porous \\ $161-251 &$ Oblong to rounded, blocky to smooth, dense, low matrix porosity, thin beds of more porous rock \\ $251-260 &$ Rounded, pitted, grainy, small vugs porous \\ $260-335 &$ Rounded, smooth to pitted, low matrix porosity, small vugs, thin beds of more porous rock \\ $335-350 &$ Rounded, smooth to pitted, low to moderate porosity, small vugs \\ $350-357 &$ Rounded, smooth, dense, low matrix porosity \\ $357-370 &$ Rounded, pitted, small vugs, porous \\ $370-395 &$ Rounded, smooth, dense, small vugs, low matrix porosity \\ $395-399 &$ Rounded, smooth, pitted, vuggy, porous \\ $399-456 &$ Rounded, smooth, dense, small vugs, low matrix porosity, thin beds of very vuggy rock \\ $456-460 &$ Rounded, grainy, porous \end{aligned}




\begin{aligned} $\begin{array}{c}\text { Depth } \\ \text { interval } \\ \text { (feet) }\end{array} &$ Observation \\ \hline $460-465 &$ Rounded, smooth, dense, low matrix porosity \\ $465-469 &$ Rounded, grainy, porous \\ $469-586 &$ Rounded, smooth, dense, thin beds of porous rock, low matrix porosity \\ $586-589 &$ Rounded, blocky, pitted, low matrix porosity \\ $589-605 &$ Rounded, pitted, vuggy, porous \\ $605-615 &$ Rounded, smooth, dense, low matrix porosity \\ $615-622 &$ Rounded, pitted, vuggy, porous \\ $622-628 &$ Rounded, smooth, slightly pitted, low matrix porosity \\ $628-641 &$ Rounded, pitted, vuggy, porous \\ 641 & Total depth logged \end{aligned}

\section{Well 13}

Well 13 is approximately $2,000 \mathrm{ft}$ west of well 15 .

\section{Notable discontinuous features}

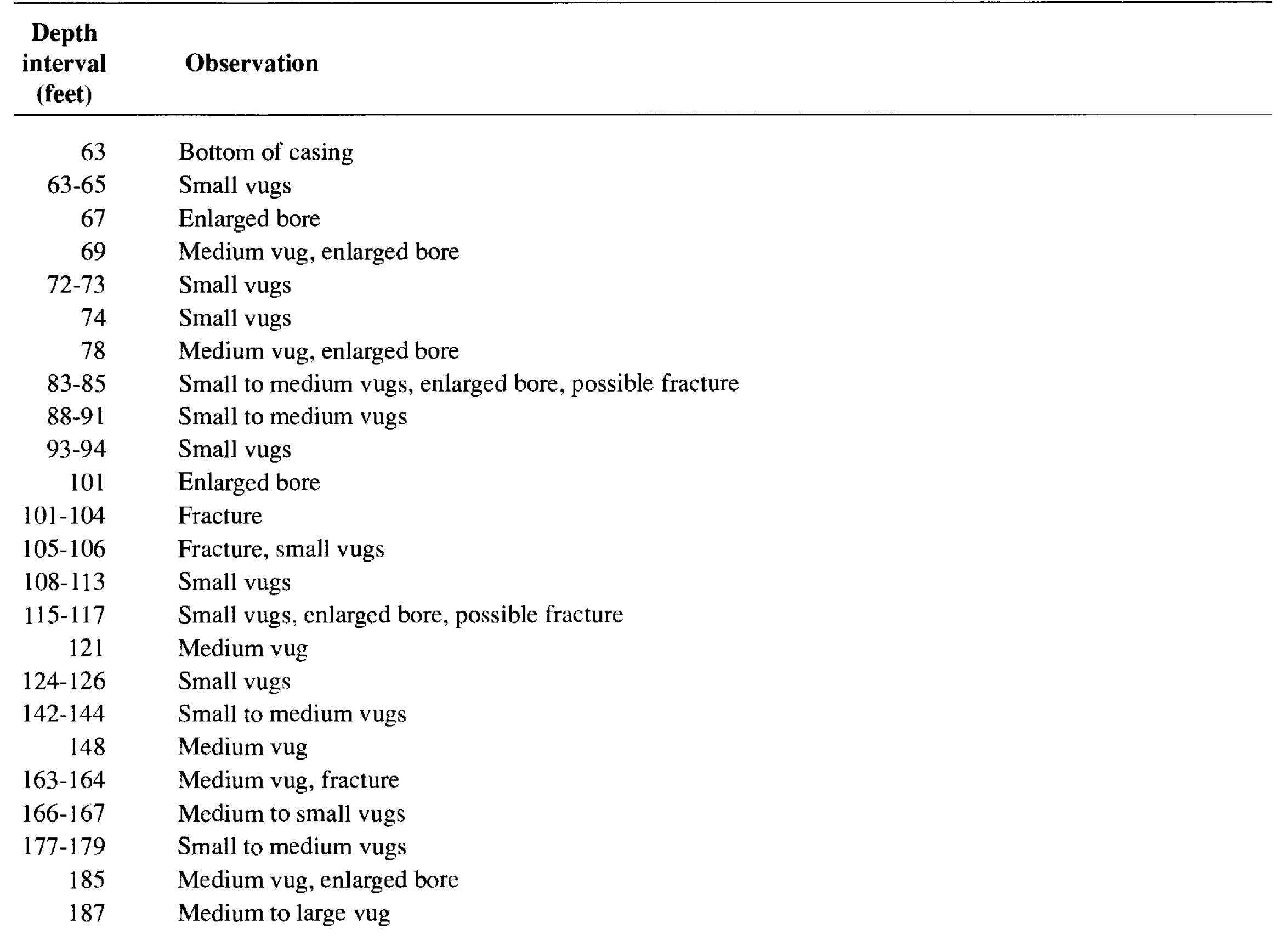




\begin{aligned} $\begin{array}{c}\text { Depth } \\ \text { interval } \\ \text { (feet) }\end{array} &$ Observation \\ \hline 190 & Small to medium vug \\ $196-200 &$ Small vugs \\ 203 & Small vugs \\ 206 & Small vugs \\ 207 & Small to medium vugs \\ 213 & Fracture \\ $214-216 &$ Small to medium vugs \\ $222-225 &$ Small to medium vugs, short fracture at 224 ft \\ $238-242 &$ Small vugs \\ 242 & Fracture \\ 245 & Small vug \\ $264-265 &$ Small vugs, fracture, enlarged bore \\ 268 & Fracture \\ 269 & Small vugs \\ $274-276 &$ Small vugs \\ $280-281 &$ Fracture, small vug \\ $285-286 &$ Fracture \\ 291 & Small vugs \\ 295 & Small vugs \\ 302 & Small vugs \\ $304-308 &$ Small to medium vugs \\ $334-336 &$ Small vugs \\ 336 & Total depth \\ & \\ & \end{aligned}

\section{Summary of Borehole Wall Characteristics}

Notable continuous features

\begin{aligned} \hline \multicolumn{1}{c}{$\begin{array}{c}\text { Depth } \\ \text { interval } \\ \text { (feet) }\end{array}$} & Observation \\ \hline 63 & Bottom of casing \\ $63-72 &$ Rounded, smooth, dense, low matrix porosity \\ $72-74 &$ Rounded, rough, grainy, porous \\ $74-77 &$ Rounded, smooth, dense, small vugs, low matrix porosity \\ $77-84 &$ Rounded, rough, pitted, dense, low matrix porosity \\ $84-96 &$ Rounded to irregular, blocky, smooth, dense, low matrix porosity \\ $96-98 &$ Rounded, rough, pitted, porous \\ $98-101 &$ Rounded, smooth, dense, pitted, low matrix porosity \\ $101-103 &$ Rounded, smooth, dense, low matrix porosity \\ $103-106 &$ Rounded, rough, pitted, vuggy, porous \\ $106-126 &$ Rounded, smooth, dense, pitted, low matrix porosity \\ $126-135 &$ Rounded, rough, grainy, porous \\ $135-144 &$ Rounded, smooth, dense, low matrix porosity \\ $144-145 &$ Rounded, rough, uneven, porous \\ $145-163 &$ Rounded, smooth, dense, pitted, low matrix porosity \\ $163-167 &$ Rounded, rough, uneven, porous \\ $167-170 &$ Rounded, smooth, dense, low matrix porosity \end{aligned}




\begin{tabular}{|c|c|}
\hline $\begin{array}{c}\text { Depth } \\
\text { interval } \\
\text { (feet) }\end{array}$ & Observation \\
\hline
\end{tabular}

170-179 Rounded, rough, uneven, pitted, porous

179-194 Rounded, smooth, pitted, low matrix porosity

194-196 Rounded, grainy, pitted, porous

196-257 Rounded to irregular, smooth to slightly pitted, dense, low matrix porosity

257-264 Rounded, grainy, porous

264-265 Irregular, broken, rough, uneven, low matrix porosity

265-274 Rounded, grainy to pitted, rough, porous

274-327 Rounded, smooth, dense, low matrix porosity

327-329 Rounded to irregular, rough, uneven, pitted, porous

329-332 Rounded, pitted, dense, low matrix porosity

332-334 Rounded to uneven, irregular, rough, pitted, low matrix porosity

334-336 Rounded, smooth, pitted, dense, low matrix porosity

\section{Well 15}

Well 15 was logged while it was being pumped at a rate of $980 \mathrm{gal} / \mathrm{min}$.

\section{Notable discontinuous features}

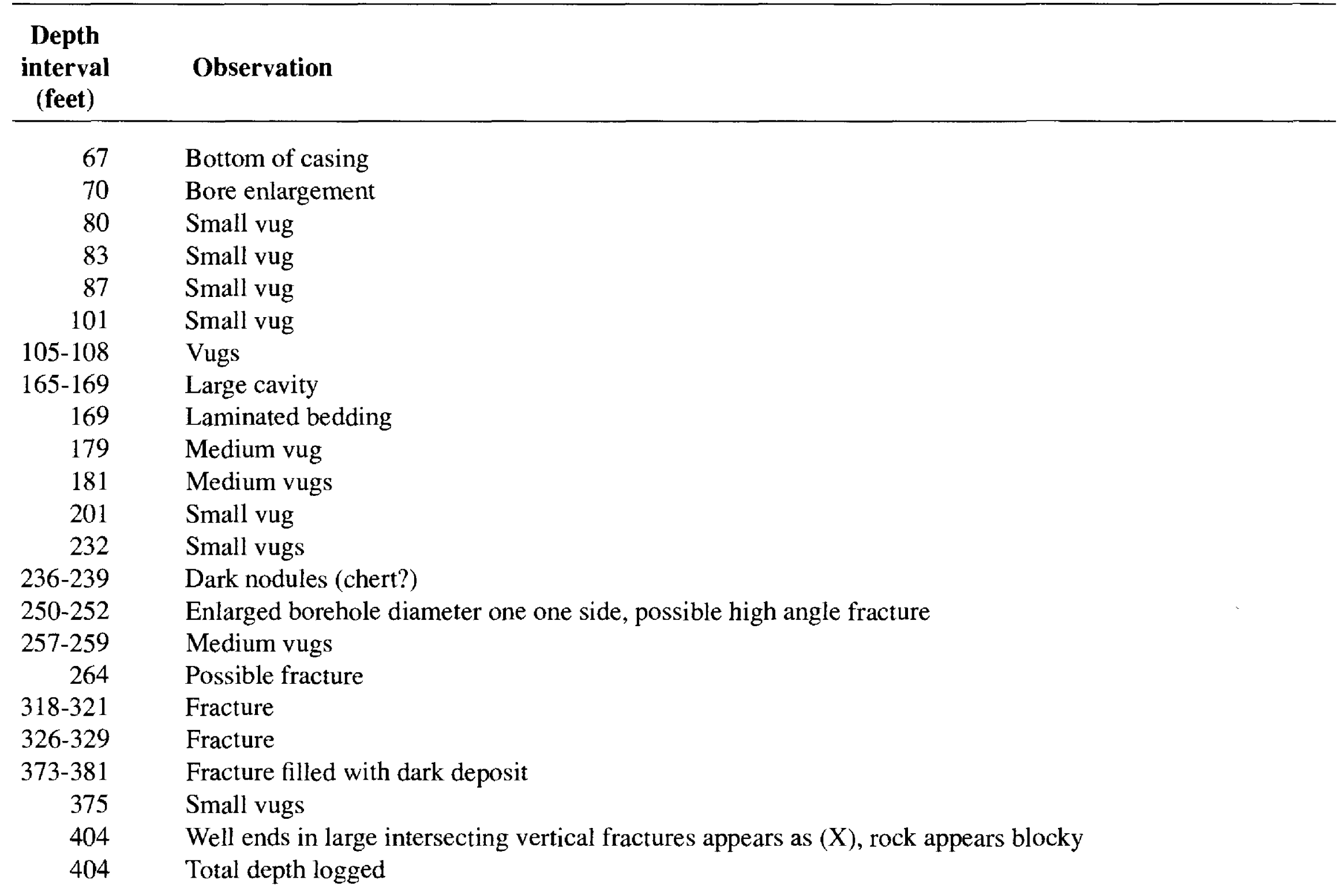




\title{
Summary of Borehole Wall Characteristics
}

\section{Notable continuous features}

\author{
Depth \\ interval \\ Observation \\ (feet) \\ $67 \quad$ Bottom of casing \\ 67-71 Rounded, pitted, dense, low matrix porosity \\ 71-74 Irregular, blocky, pitted, dense, low matrix porosity \\ 74-82 Rounded to slightly irregular, pitted, vuggy, moderate porosity \\ 82-102 Rounded, pitted, smooth, dense, low matrix porosity \\ 102-109 Rounded, blocky, pitted, vuggy, porous \\ 109-116 Rounded, smooth, dense, low matrix porosity \\ 116-125 Rounded, pitted, grainy, porous \\ 125-128 Rounded, smooth, dense, low matrix porosity \\ 128-129 Rounded, pitted, grainy, porous \\ 129-134 Rounded, pitted, dense, low matrix porosity \\ 134-141 Rounded, pitted, porous \\ 141-150 Rounded, smooth, dense, low matrix porosity \\ 150-165 Rounded, pitted, grainy, porous \\ 165-169 Large cavity, bore walls not visible \\ 169-201 Rounded, blocky, dense, low matrix porosity \\ 201-203 Rounded, pitted, porous \\ 203-208 Rounded, smooth, dense, low matrix porosity \\ 208-214 Rounded, pitted, grainy, porous \\ 214-222 Rounded, smooth, pitted, dense, low matrix porosity \\ 222-223 Rounded, pitted, porous \\ 223-230 Rounded, smooth, slightly pitted, low matrix porosity \\ 230-240 Rounded, pitted, porous \\ 240-249 Rounded, smooth, pitted, dense low matrix porosity \\ 249-269 Rounded, pitted, grainy, vuggy, porous, interlayered beds of smooth, dense, low porosity rock \\ 269-336 Rounded, smooth, slightly pitted, dense, low matrix porosity \\ 336-345 Rounded to slightly irregular, pitted, vuggy, porous \\ 345-380 Rounded, smooth, slightly pitted, dense, low matrix porosity \\ 380-386 Rounded to slightly irregular, blocky, pitted, moderate porosity \\ 386-393 Rounded, pitted, dense, low matrix porosity \\ 393-397 Rounded, pitted, vuggy, porous \\ 397-401 Rounded, pitted, dense, low matrix porosity \\ 401-404 Irregular, blocky, dense, enlarged hole, low matrix porosity
}




\section{Well 15A}

Well 15A was logged while pumping well 15 , located $103 \mathrm{ft}$ due west, at a rate of $980 \mathrm{gal} / \mathrm{min}$. Much of the borehole wall was covered by what appears to be iron bacterial slime.

\section{Notable discontinuous features}

\begin{tabular}{|c|c|}
\hline $\begin{array}{c}\text { Depth } \\
\text { interval } \\
\text { (feet) }\end{array}$ & Observation \\
\hline 57 & Bottom of casing \\
\hline 65 & Fracture \\
\hline 69 & Fracture \\
\hline $79-80$ & Fracture \\
\hline 84 & Medium vug \\
\hline 98 & Small vugs \\
\hline 101 & Medium vug \\
\hline 104 & Medium vug \\
\hline 141 & Medium vug \\
\hline 158 & Small to medium vug \\
\hline 162 & Small vug \\
\hline 164 & Small vug \\
\hline 166 & Fracture \\
\hline 168 & Small vug \\
\hline 169 & Small to medium vug with possible high angle fracture \\
\hline 177 & Fracture \\
\hline 181 & Medium vug \\
\hline 182 & Fracture and enlarged bore hole \\
\hline 185 & Large to medium vug \\
\hline $189-204$ & Small vugs \\
\hline 213 & Small to medium vugs with possible high angle fracture \\
\hline 214 & Fracture \\
\hline 217 & Small vugs \\
\hline 226 & Small vugs \\
\hline $238-241$ & Medium vugs \\
\hline $250-251$ & Medium vugs \\
\hline 259 & Small vugs \\
\hline 266 & Fracture \\
\hline 273 & Medium vugs \\
\hline $323-331$ & Fracture \\
\hline $335-343$ & Fractured zone \\
\hline 352 & Small vug \\
\hline 357 & Small vugs \\
\hline 369 & Small vug \\
\hline $371-378$ & Small vugs \\
\hline 382 & Small to medium vugs \\
\hline 388 & Small vug \\
\hline 397 & Small to medium vug \\
\hline 400 & Small vug \\
\hline 402 & Fracture \\
\hline 405 & Slime covers camera \\
\hline 405 & Total depth logged \\
\hline
\end{tabular}




\section{Summary of Borehole Wall Characteristics}

\section{Notable continuous features}

\begin{tabular}{|c|c|}
\hline $\begin{array}{c}\text { Depth } \\
\text { interval } \\
\text { (feet) }\end{array}$ & Observation \\
\hline $57-63$ & Rounded, irregular, blocky, rough, dense, low matrix porosity \\
\hline $63-95$ & Rounded, grainy, pitted, porous \\
\hline $95-105$ & Rounded, pitted, grainy, dense, less porous \\
\hline $105-110$ & Rounded, smooth, pitted, dense, low matrix porosity \\
\hline $110-119$ & Rounded, grainy, pitted, very porous \\
\hline $119-122$ & Rounded, pitted, less porous \\
\hline $122-127$ & Rounded, smooth, pitted, low matrix porosity \\
\hline $127-131$ & Rounded, pitted, grainy, porous \\
\hline $131-136$ & Rounded, pitted, dense, less porous \\
\hline $136-142$ & Rounded, smooth, dense, low matrix porosity \\
\hline $142-158$ & Rounded, pitted, grainy, porous \\
\hline $158-160$ & Rounded, smooth to slightly pitted, dense, low matrix porosity \\
\hline $160-163$ & Rounded, pitted, porous \\
\hline $163-214$ & Rounded, smooth, slightly pitted, dense, low matrix porosity, with thin beds of porous rock \\
\hline 214-248 & Rounded, irregular, blocky, smooth, dense, low matrix porosity \\
\hline $248-250$ & Rounded, pitted, grainy, porous \\
\hline $250-335$ & Rounded, smooth, slightly pitted, dense, low matrix porosity \\
\hline $335-347$ & lrregular, blocky near fractures, pitted, porous \\
\hline $347-378$ & Rounded, slightly pitted, moderate to low matrix porosity \\
\hline 378-385 & Rounded, pitted, porous \\
\hline $385-392$ & Rounded, slightly pitted to smooth, dense, low matrix porosity \\
\hline $392-395$ & Rounded, pitted, porous \\
\hline $395-405$ & Slime covers borehole wall \\
\hline 405 & Slime covers camera \\
\hline
\end{tabular}

\section{Well 20}

Well 20 was logged while pumping well 15, located $200 \mathrm{ft}$ due west, at a rate of $980 \mathrm{gal} / \mathrm{min}$.

\section{Notable discontinuous features}

\begin{aligned} $\begin{array}{c}\text { Depth } \\ \text { interval } \\ \text { (feet) }\end{array} &$ Observation \\ \hline 38 & Bottom of casing \\ 39 & Short fracture with sediment flowing into bore when camera gets stuck in casing \\ 56 & Medium vugs \\ $65-80 &$ Several zones of small vugs, some so solutionized that they are almost cavities. \\ $81-83 &$ Small to medium vugs \\ $84-86 &$ Short fracture, enlarged bore \\ 87 & Small vug \\ $102-118 &$ Small vugs \end{aligned}




\begin{tabular}{|c|c|}
\hline $\begin{array}{c}\text { Depth } \\
\text { interval } \\
\text { (feet) }\end{array}$ & Observation \\
\hline 147 & Medium vug \\
\hline $147-149$ & Short fracture \\
\hline $165-167$ & Small vugs \\
\hline 174 & Medium vug \\
\hline $177-186$ & Layered zones of small vugs \\
\hline 322 & Hole blocked \\
\hline 322 & Total depth logged \\
\hline \multicolumn{2}{|c|}{ Summary of Borehole Wall Characteristics } \\
\hline \multicolumn{2}{|c|}{ Notable continuous features } \\
\hline $\begin{array}{c}\text { Depth } \\
\text { interval } \\
\text { (feet) }\end{array}$ & Observation \\
\hline 39 & Bottom of casing \\
\hline $39-57$ & Rounded, smooth, dense, low matrix porosity \\
\hline $57-66$ & Rounded to irregular, rough, pitted, porous \\
\hline $66-72$ & Rounded, smooth, low matrix porosity \\
\hline $72-80$ & Rounded, smooth, vuggy, porous \\
\hline $80-89$ & Rounded, smooth to irregular, blocky, dense, low matrix porosity \\
\hline $89-91$ & Rounded, smooth, dense, low matrix porosity \\
\hline $91-96$ & Rounded to irregular, pitted, porous \\
\hline $96-100$ & Rounded, smooth, slightly pitted, low matrix porosity \\
\hline $100-104$ & Rounded, pitted, vuggy, porous \\
\hline 104-108 & Rounded, smooth, dense, low matrix porosity \\
\hline $108-109$ & Rounded, pitted, grainy, porous \\
\hline $109-121$ & Rounded, smooth, slightly pitted, dense, low matrix porosity \\
\hline $121-123$ & Rounded to irregular, blocky, rough, porous \\
\hline $123-150$ & Rounded, smooth, pitted, dense, low matrix porosity \\
\hline $150-160$ & Rounded, rough, pitted, porous \\
\hline $160-165$ & Rounded, smooth, pitted, dense, low matrix porosity \\
\hline $165-174$ & Rounded, irregular, blocky, dense, low matrix porosity \\
\hline $174-184$ & Rounded, smooth to uneven, dense, thin beds of vuggy, porous rock, low matrix porosity \\
\hline 184-186 & Rounded, uneven, blocky, low matrix porosity \\
\hline $186-239$ & Rounded, smooth, pitted, dense, low matrix porosity \\
\hline $239-245$ & Rounded, rough, vuggy, pitted, porous \\
\hline $245-253$ & Rounded to irregular, pitted, vuggy, porous \\
\hline $253-254$ & Rounded, smooth, dense, low matrix porosity \\
\hline $254-267$ & Rounded to irregular, blocky, pitted, porous \\
\hline $267-322$ & Rounded, smooth, dense, low matrix porosity \\
\hline 322 & Hole blocked \\
\hline
\end{tabular}




\section{Avon Park Monitor Well}

This well was logged while pumping well 15 , located $867 \mathrm{ft}$ to the southwest.

\section{Notable discontinuous features}

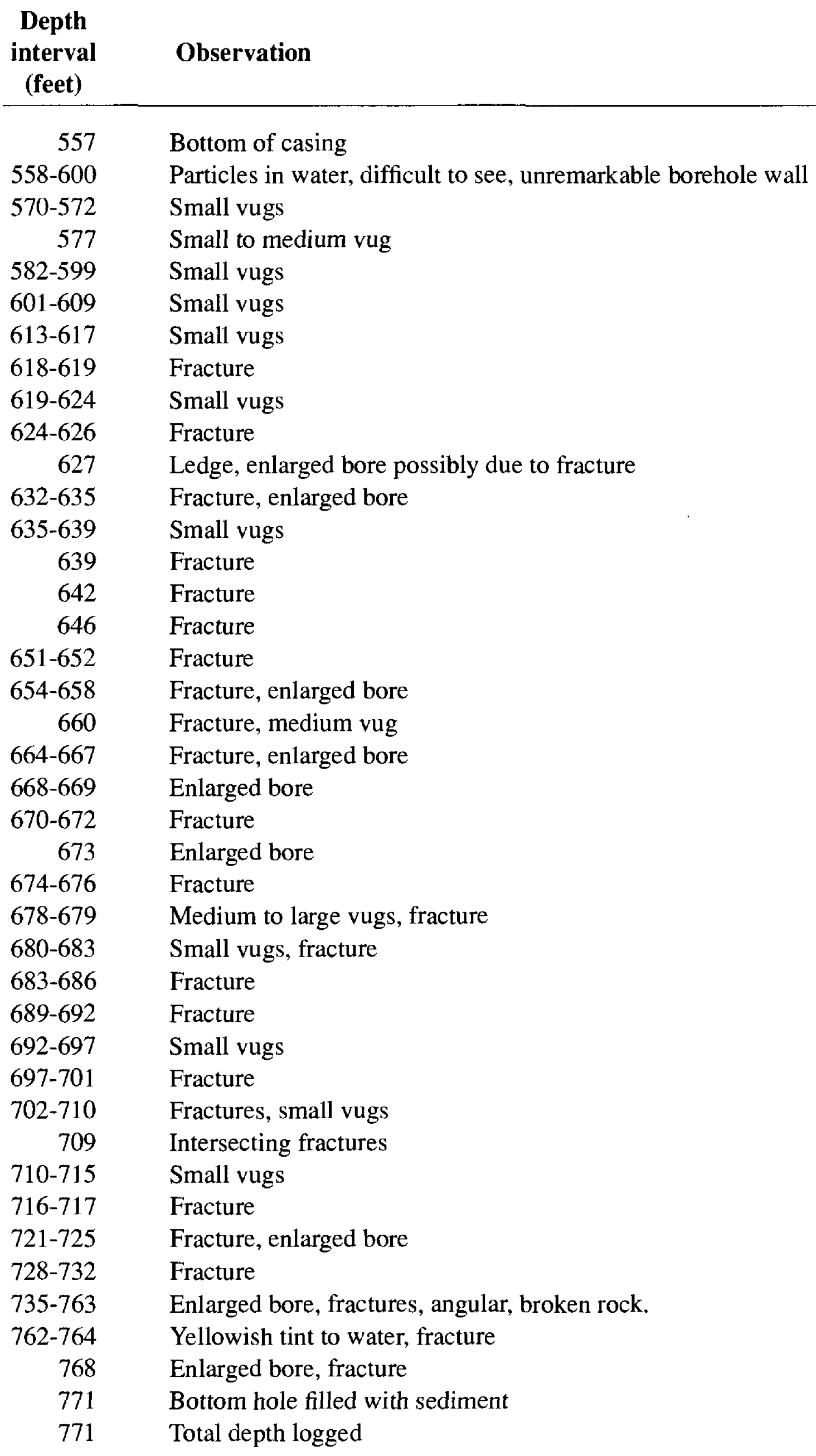




\section{Summary of Borehole Wall Characteristics}

\section{Notable continuous features}

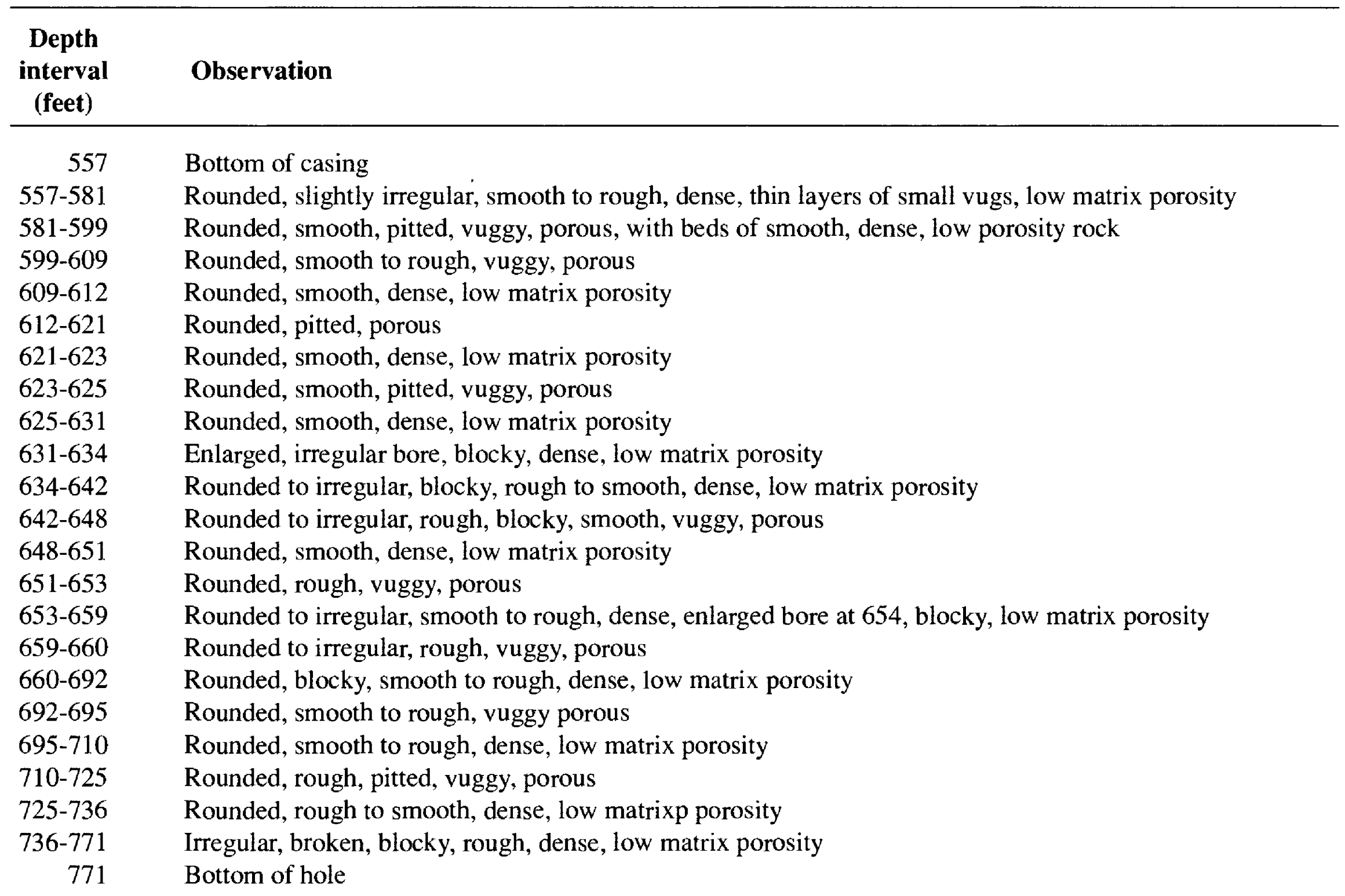

\section{Ocala Monitor Well}

This well was logged while pumping well 15 , located $219 \mathrm{ft}$ away, at a rate of $980 \mathrm{gal} / \mathrm{min}$.

\section{Notable discontinuous features}

\begin{aligned} & \hline $\begin{array}{c}\text { Depth } \\ \text { interval } \\ \text { (feet) }\end{array}$ Observation \\ & \hline 247 Bottom of casing \\ & $247-254$ Cement in bore \\ & 254 Small vugs, rough, pitted surface \\ & $260-262$ Medium vugs \\ & 268 Fracture \\ & $277-278$ Fracture \\ & $279-281$ Medium to small vugs \\ & $297-298$ Small to medium vugs \\ & 306 Medium vugs \\ & 324 Small vugs \\ & \hline\end{aligned}




\begin{aligned} $\begin{array}{c}\text { Depth } \\ \text { interval } \\ \text { (feet) }\end{array} &$ Observation \\ \hline 333 & Small vugs \\ 340 & Medium vug \\ 341 & Small vug \\ $383-397 &$ Medium to small vugs \\ $403-406 &$ Fracture, small vugs \\ $407-412 &$ Small vugs \\ $408-412 &$ Fracture \\ $418-422 &$ Small and medium vugs \\ $421-425 &$ Fracture \\ 432 & Small vug \\ 444 & Small vugs \\ 446 & Total depth \end{aligned}

\section{Summary of Borehole Well Characteristics}

\section{Notable continuous features}

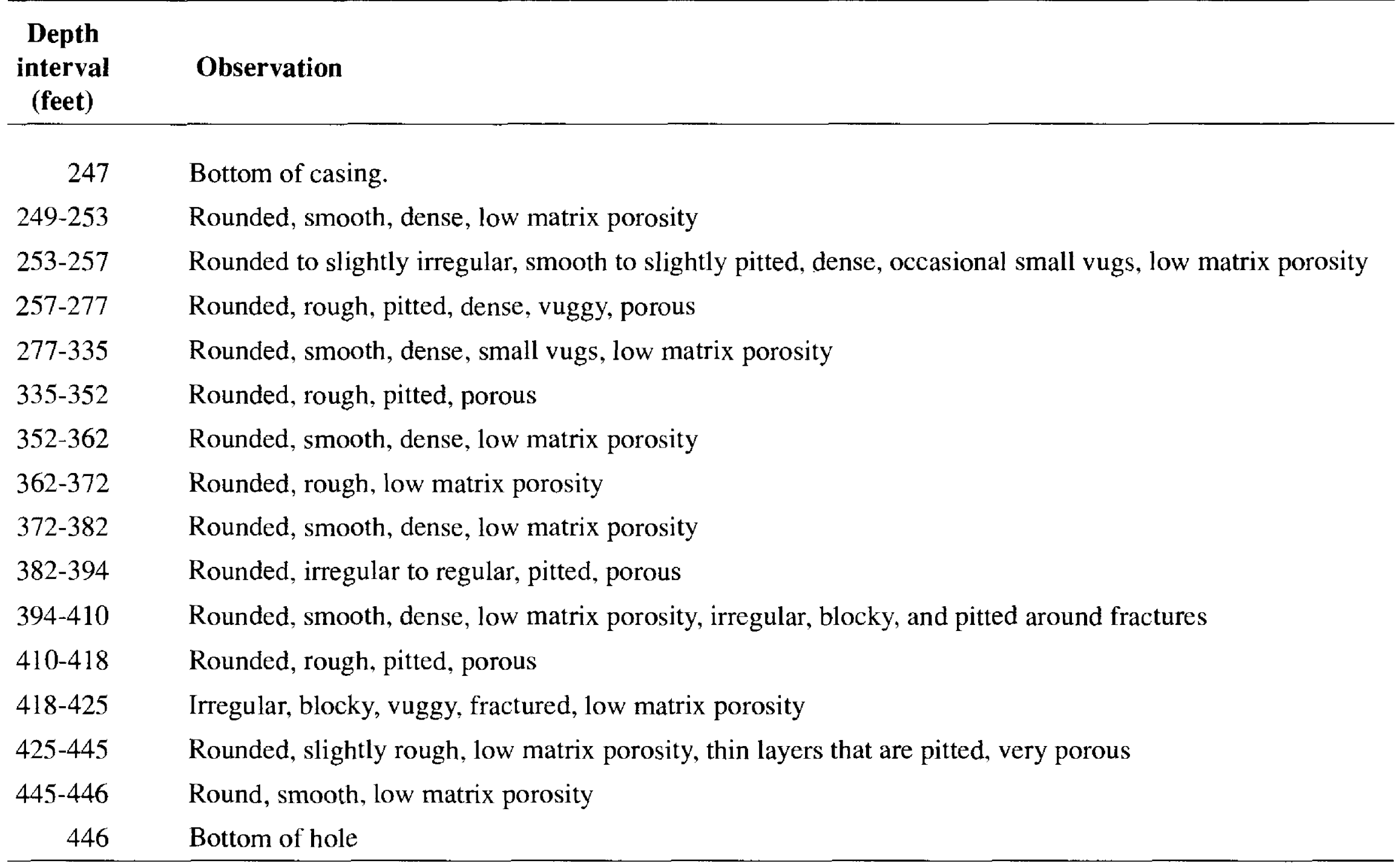

